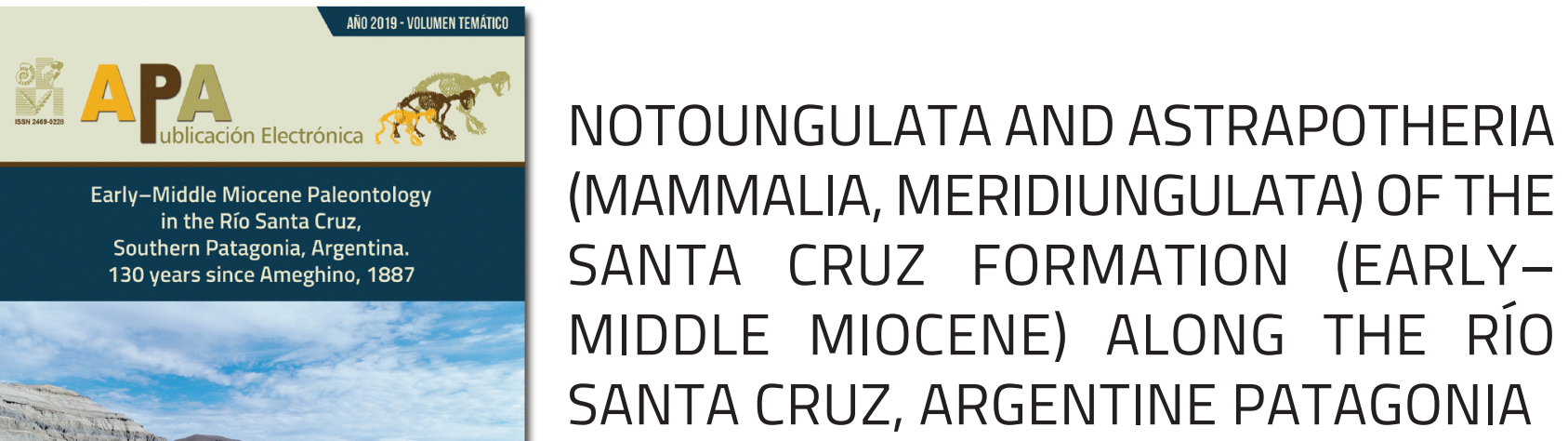

MERCEDES FERNÁNDEZ $1,2,3$

NAHUEL A. MUÑOZ1,3,4

\begin{abstract}
${ }^{1}$ Universidad Nacional de Luján, Departamento de Ciencias Básicas. Ruta 5 y Av. Constitución, 6700 Luján, Buenos Aires, Argentina.
2División Paleontología de Vertebrados, Museo Argentino de Ciencias Naturales "Bernardino Rivadavia". Av. Ángel Gallardo 470, C1405DJR Ciudad Autónoma de Buenos Aires, Argentina.

${ }^{3}$ Consejo Nacional de Investigaciones Científicas y Técnicas (CONICET).

4División Paleontología Vertebrados, Unidades de Investigación Anexo Museo, Facultad de Ciencias Naturales y Museo, Universidad Nacional de La Plata. Av. 60 y 122, B1904 La Plata, Argentina.
\end{abstract}

Recibido: 22 de marzo 2019 - Aceptado: 19 de septiembre 2019

Para citar este artículo: Mercedes Fernández, and Nahuel A. Muñoz (2019). Notoungulata and Astrapotheria (Mammalia, Meridiungulata) of the Santa Cruz Formation (Early-Middle Miocene) along the Río Santa Sruz, Argentine Patagonia. Publicación Electrónica de la Asociación Paleontológica Argentina 19 (2): 138-169.

Link a este artículo: http://dx.doi.org/10.5710/PEAPA.19.09.2019.288

DESPLAZARSE HACIA ABAJO PARA ACCEDER AL ARTÍCULO

Asociación Paleontológica Argentina Maipú $6451^{\circ}$ piso, C1006ACG, Buenos Aires República Argentina Tel/Fax (54-11) 4326-7563 Otros artículos en Publicación Electrónica de la APA 19(2): Web: www.apaleontologica.org.ar

\section{J.I. Cuitiño et al.}

STRATIGRAPHY AND DEPOSITIONAL ENVIRONMENTS OF THE SANTA CRUZ FORMATION (EARLY-MIDDLE MIOCENE) ALONG THE RÍO SANTA CRUZ, SOUTHERN PATAGONIA, ARGENTINA

\section{L.M. Pérez et al.}

DIPLODON CF. COLHUAPIENSIS (BIVALVIAHYRIIDAE) IN SANTA CRUZ FORMATION (EARLY-MIDDLE MIOCENE), AT THE RÍO SANTA CRUZ, PATAGONIA, ARGENTINA. STRATIGRAPHIC AND PALEOENVIRONMENTAL CONSIDERATIONS

\section{Arnal et al.}

MIOCENE CAVIOMORPHS FROM THE RÍO SANTA CRUZ (ARGENTINEAN PATAGONIA): AN UPDATE OF THIS CHARACTERISTIC RODENT FAUNA 


\title{
NOTOUNGULATA AND ASTRAPOTHERIA (MAMMALIA, MERIDIUNGULATA) OF THE SANTA CRUZ FORMATION (EARLY-MIDDLE MIOCENE) ALONG THE RÍO SANTA CRUZ, ARGENTINE PATAGONIA
}

\author{
MERCEDES FERNÁNDEZ1,2,3, AND NAHUEL A. MUÑOZ1,3,4
}

\begin{abstract}
'Universidad Nacional de Luján, Departamento de Ciencias Básicas. Ruta 5 y Av. Constitución, 6700 Luján, Buenos Aires, Argentina.
2División Paleontología de Vertebrados, Museo Argentino de Ciencias Naturales "Bernardino Rivadavia". Av. Ángel Gallardo 470, C1405DJR Ciudad Autónoma de Buenos Aires, Argentina. mfernandez@macn.gov.ar

${ }^{3}$ Consejo Nacional de Investigaciones Científicas y Técnicas (CONICET).

4División Paleontología Vertebrados, Unidades de Investigación Anexo Museo, Facultad de Ciencias Naturales y Museo, Universidad Nacional de La Plata. Av. 60 y 122, B1904 La Plata, Argentina.nahuelmunoz@fcnym.unlp.edu.ar
\end{abstract}

\begin{abstract}
This contribution details new records of Notoungulata and Astrapotheria from the exposures of the Santa Cruz Formation in the Río Santa Cruz (Early-Middle Miocene; Province of Santa Cruz). The astrapothere Astrapotherium sp. Burmeister, the notoungulate toxodonts Homalodotherium sp. Flower, Nesodon sp. Owen and Adinotherium sp. Ameghino, and the typotheres Hegetotherium mirabile Ameghino, Interatherium sp. Ameghino, Protypotherium sp. Ameghino, P. attenuatum Ameghino, P. australe Ameghino and P. praerutilum Ameghino are recognized in the localities Barrancas Blancas and Segundas Barrancas Blancas. Nesodon imbricatus Owen was recorded in the former and Adinotherium ovinum (Owen) in the latter locality. The typothere Pachyrukhos moyani Ameghino was identified only in Segundas Barrancas Blancas, but with numerous specimens. Only the large ungulates Astrapotherium magnum (Owen) and Adinotherium sp. were recorded in Yaten Huageno. At a generic level, Barrancas Blancas and Segundas Barrancas Blancas only differ by the presence of Pachyrukhos Ameghino in the latter; at Yaten Huageno the Typotheria, Homalodotheriidae and Nesodon have not been recorded. The general faunal composition, including the larger samples from Barrancas Blancas and Segundas Barrancas Blancas, matches the record from the better-known Santacrucian localities from the Atlantic coast. This faunal similarity implies that similar environmental conditions prevailed in the two areas, indicating that the localities from Río Santa Cruz, as the Atlantic coastal localities, would have constituted a complex mosaic of open and closed habitats.
\end{abstract}

Key words. Notoungulates. Astrapotheres. Typotheria. Toxodontia. Ameghino. Santacrucian.

Resumen. NOTOUNGULATA Y ASTRAPOTHERIA (MAMMALIA, MERIDIUNGULATA) DE LA FORMACION SANTA CRUZ (MIOCENO TEMPRANOMEDIO) A LO LARGO DEL RÍO SANTA CRUZ, PATAGONIA ARGENTINA. Esta contribución involucra un reporte faunístico de los nuevos registros de Notoungulata y Astrapotheria provenientes de los yacimientos de la Formación Santa Cruz del Río Santa Cruz (Mioceno Temprano-Medio; provincia de Santa (ruz). El astrapoterio Astrapotherium sp., los notoungulados toxodontes Homalodotherium sp. Flower, Nesodon sp. Owen y Adinotherium sp. Ameghino, y los tipoterios Hegetotherium mirabile Ameghino, Interatherium sp. Ameghino, Protypotherium sp. Ameghino, P. attenuatum Ameghino, P. australe Ameghino y P. praerutilum Ameghino fueron reconocidos en Barrancas Blancas y Segunda Barrancas Blancas. Las especies Nesodon imbricatus Owen y Adinotherium ovinum (Owen) fueron identificados en la primera y en la segunda localidad, respectivamente. El tipoterio Pachyrukhos moyani Ameghino fue identificado únicamente en Segundas Barrancas Blancas, pero a través de numerosos ejemplares. Solo los ungulados de gran talla Astrapotherium magnum (Owen) y Adinotherium sp. fueron reconocidos en Yaten Huageno. A un nivel supraespecífico, Barrancas Blancas y Segundas Barrancas Blancas difieren por la presencia de Pachyrukhos Ameghino en la segunda, mientras que en Yaten Huageno los Typotheria, Homalodotheriidae y Nesodon no han sido identificados. La composición faunística general, incluyendo las grandes muestras provenientes de Barrancas Blancas y Segundas Barrancas Blancas, coincide con la registrada en las localidades Santacrucenses más conocidas de la costa Atlántica. Esta similitud faunística permite inferir, preliminarmente, similares condiciones ambientales, indicando que las localidades del Río Santa Cruz podrían haber constituido un complejo mosaico de ambientes abiertos y cerrados.

Palabras clave. Notoungulados. Astrapoterios. Typotheria. Toxodontia. Ameghino. Santacrucense.

THE EXTINCT South American native ungulates (SANUs) constitute a remarkable widespread and highly diverse group of mammals. They consist of five orders: Astrapotheria, Litopterna, Notoungulata, Pyrotheria, and Xenungulata 
(Patterson and Pascual, 1968; Simpson, 1980; Cifelli, 1993; Bond et al., 1995). Their phylogenetic relationships have been little explored, and although there has been progress in the last few years, they are still not resolved (e.g., Cifelli, 1985, 1993; Gelfo et al., 2008; Billet, 2010, 2011; Buckley, 2015; Welker et al., 2015; Fig. 1).

Among the SANUs, only notoungulates, astrapotheres and litopterns survived until the Miocene, or later. The order
Notoungulata is by far the most diverse and abundant clade within the SANUs at a morphological, taxonomic and ecological level (Simpson, 1936; Patterson and Pascual, 1972; Cifelli, 1993; Croft, 1999; Cassini et al., 2012). They are united by features of the ear region (Patterson, 1934; Simpson, 1948, 1967, 1980) and cheek teeth, including a structure on the upper molars known as the "crochet" (Patterson, 1934; Simpson, 1948, 1967, 1980). Notoungulates are divided into

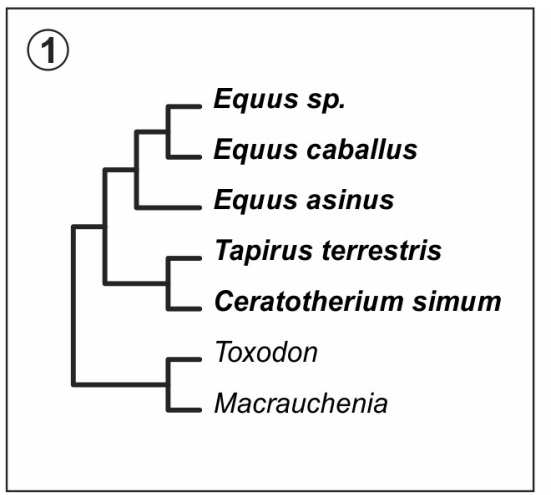

(2)

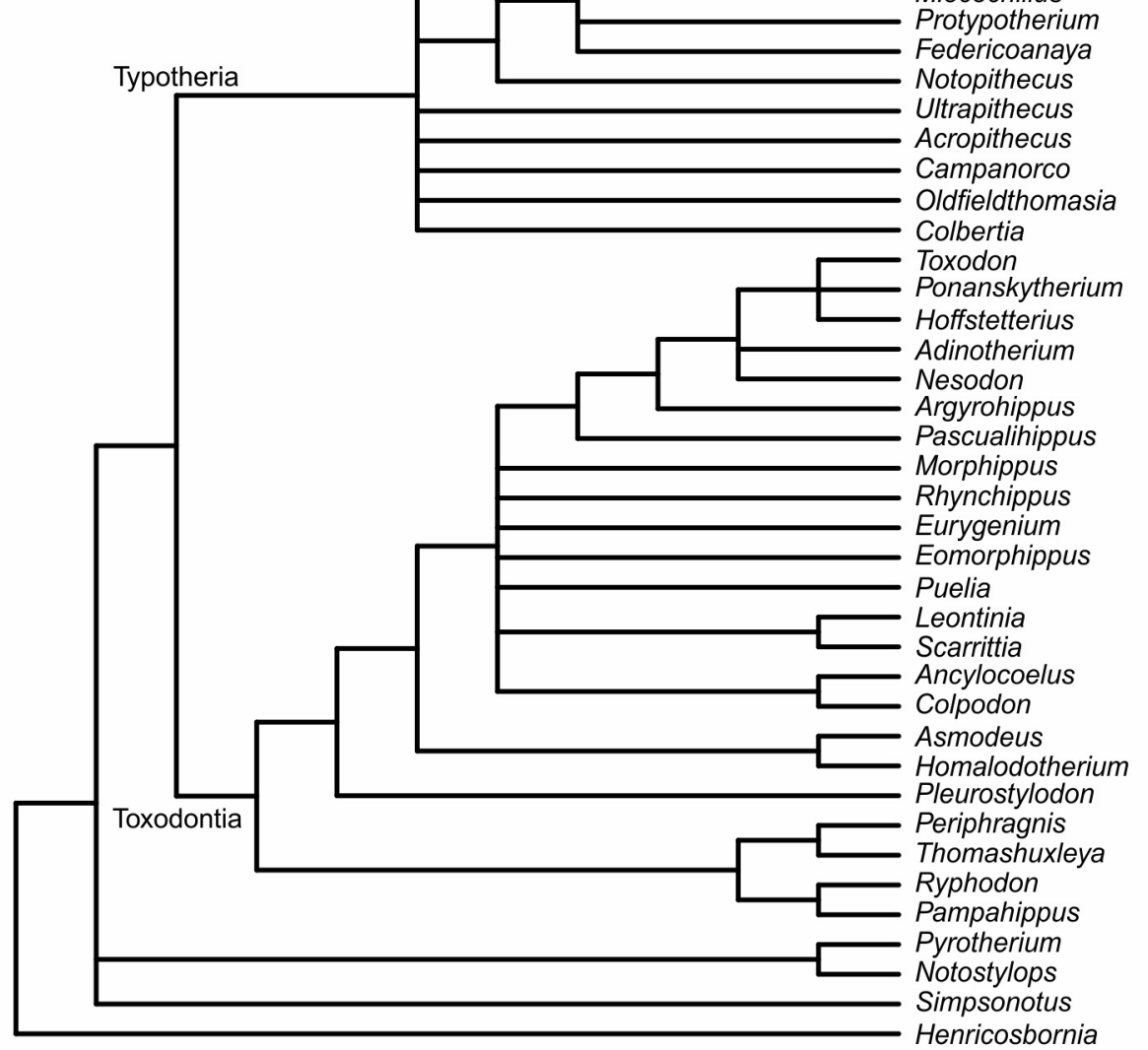

Hegetotheriidae

Archaeohyracidae

Archaeohyracidae

Mesotheriidae

Archaeohyracidae Archaeohyracidae

Interatheriidae

Oldfieldthomasiidae Archaeopithecidae;

Oldfieldthomasiidae Oldfieldthomasiidae

Toxodontidae

Notohippidae

Notohippidae

Notohippidae

Notohippidae

Notohippidae

Notohippidae

Isotemnidae

Leontiniidae

Homalodotheriidae

Isotemnidae

Isotemnidae

Isotemnidae

Isotemnidae

Isotemnidae

Notostylopidae

Henricosborniidae

Henricosborniidae

Figure 1. Phylogenetic hypothesis. 1, Clade Panperissodactyla, modified from Welker et al. (2015); 2, Clade Notoungulata, modified from Billet (2011). 
two basal (and unnatural) families (Notostylopidae and Henricosborniidae) plus two monophyletic suborders, Toxodontia and Typotheria (Cifelli, 1993; Billet, 2011). The toxodonts include large to very large herbivores that share some convergent features with horses, bisons, hippos or rhinos (Ameghino, 1907; Scott, 1912; Bond, 1999), whereas the typotheres were small to medium-sized herbivores (Patterson and Pascual, 1968; Bond, 1986; Croft et al., 2004; Billet et al., 2008; Elissamburu, 2011) many of which exhibit rodent or rabbit-like cranial and/or postcranial characteristics.

Astrapotheria are among the most peculiar and largest mammals among the Tertiary native faunas of South America (Kramarz and Bond, 2009), being the only Miocene taxon with dental enamel distributed in vertically oriented HunterSchreger bands. Many astrapothere taxa exhibit strongly retracted nasals that suggest the presence of a proboscis; they have a reduced dental series, enlarged canines and brachydont rhino-like cheek teeth (Ameghino, 1894; Scott, 1937; Kramarz and Bond, 2009). The third order within the Miocene SANUs, Litopterna, includes large to very large animals similar to small horses and camelids, which are reviewed by Schmidt et al. (2019).

Notoungulates and astrapotheres are common in the Santa Cruz Formation (SCF; Burdigalian-early Langhian) in Patagonia. The unit is one of the most widespread conti- nental formations in South America, and contains the richest pre-Pleistocene assemblage of mammal skulls and articulated skeletons in the continent (Kay et al., 2008; Vizcaíno et al., 2010, 2012a). The SCF is part of the infill of the Austral (= Magallanes) Basin of the Province of Santa Cruz, and it crops out in the northwest, the central area along the Río Santa Cruz (Fernicola et al., 2014; Cuitiño et al., 2016) and Río Chalía (Vizcaíno et al., 2018), and in the southeast along the Atlantic coast (Vizcaíno et al., 2012b). The unit is composed of mudstones, tuffaceous sandstones, and tuffs deposited in fluvial environments under the influence of intense explosive pyroclastic input (see Cuitiño et al., 2019 for the geological background). The outcrops of SCF along the southern margin of the Río Santa Cruz (RSC) are concentrated in three localities (Fernicola et al., 2014, 2019): Barrancas Blancas (S $50^{\circ} 9^{\prime} 38.31^{\prime \prime}$ - W 69 40' 23.40" to S 50 '12' 31.70" - W $69^{\circ} 43^{\prime} 10.66^{\prime \prime}$ ), Segundas Barrancas Blancas (S $50^{\circ} 16^{\prime}$ $12.48^{\prime \prime}$ - W 70 $22^{\prime} 23.21^{\prime \prime}$ to S $50^{\circ} 16^{\prime} 51.90^{\prime \prime}$ - W $70^{\circ} 17^{\prime}$ 54.76"), and Yaten Huageno (S 50 '15'17.48" - W 71 ${ }^{\circ} 4^{\prime}$ 9.56" to $S 50^{\circ} 15^{\prime} 17.48^{\prime \prime}-W 71^{\circ} 4^{\prime} 9.56^{\prime \prime}$; Fig. 2). Based on radiometric ages, the entire SCF represents a span of $\sim 18.0$ to $15.6 \mathrm{Ma}$; the localities along the Atlantic coast range between 18.0 to 16.0 Ma (Fleagle et al., 2012; Perkins et al., 2012; Trayler et al., 2019), and between 18.2 to $15.6 \mathrm{Ma}$ in Río Bote and Río Santa Cruz localities (Cuitiño et al., 2016).

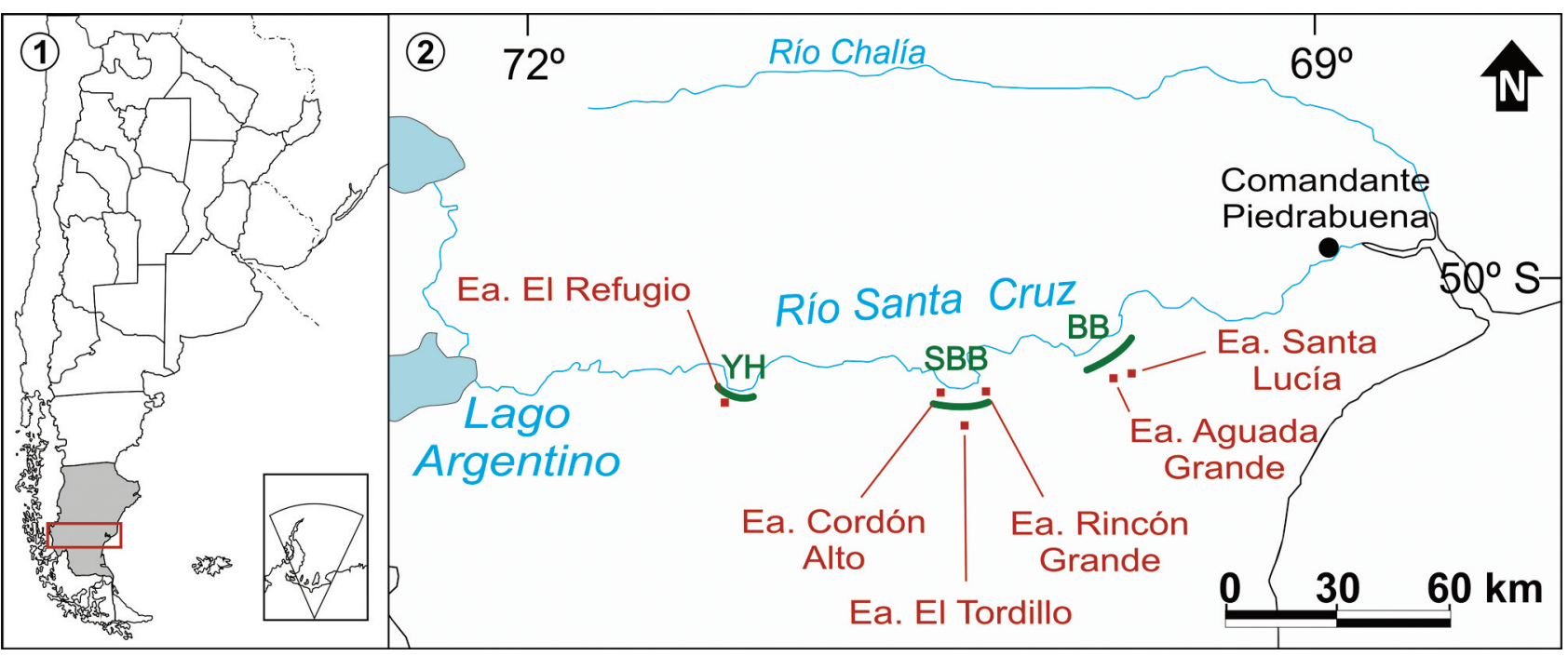

Figure 2. Map of the study area. 1, Argentina, emphasizing the Province of Santa Cruz; 2, Río Santa Cruz with the prospected localities and estancias mentioned in the text. BB, Barrancas Blancas; SBB, Segundas Barrancas Blancas; YH, Yaten Huageno; Ea., Estancia. Modified from Fernicola et al. (2014). 
The fossil remains collected by Carlos Ameghino from the exposures of the SCF along the Río Santa Cruz valley were described by his older brother Florentino Ameghino (1887a,b, 1889) and produced the data on which he based his Formación Santacruceña and Piso Santacruceño (Ameghino, 1889; currently the SCF). Ameghino (1900-1902) divided the former into two stages, naming the older as the Notohippidien and the younger as the Santacruzienne, which was later formalized as the Santacrucian SALMA by Pascual et al. (1965). Despite the historical importance of the material from the Río Santa Cruz in characterizing Santacrucian fauna, these localities passed into obscurity (Vizcaíno et al., 2012a, 2013; Fernicola et al., 2014), overshadowed by the rich faunas from extensive exposures of the SCF in the southeast of the Province of Santa Cruz along the Atlantic coast (Marshall and Pascual, 1976; Tauber, 1994, 1997a,b, 1999; Vizcaíno et al., 2012a,b; Fernicola et al., 2014, 2019). The Río Santa Cruz localities were so neglected that even the type locality of the Santacrucian SALMA was proposed to be Monte León in the coastal region (Marshall et al., 1983).

This contribution focuses on the Notoungulata and Astrapotheria recovered from the exposures of the SCF along the Río Santa Cruz valley at three localities: Barrancas Blancas, Segundas Barrancas Blancas, and Yaten Huageno, which recent extensive fieldwork has provided new material after a lapse of more than a century since the explorations of $C$. Ameghino. We report the astrapothere and notoungulate specimens recovered from these three localities along the Río Santa Cruz in the last few years, compare them with those from the Atlantic Coast localities, and propose a paleoecological scenario for these RSC localities based on the recovered astrapothere and notoungulate content.

\section{Historical and taxonomic background}

The exposures of the SCF at the Río Santa Cruz valley were first explored in 1876-1877 by Francisco Moreno (1879), who collected a few, but remarkable fossil mammals. Based on these materials, Burmeister (1879) used a wellpreserved skull to describe the new taxon Astrapotherium patagonicum Burmeister,1879 (Astrapotheria) (without Moreno's permission; Moreno, 1882, p. 114), and Florentino Ameghino (1887a) named the notoungulates Interatherium rodens Ameghino, 1887a, Protypotherium australe Ameghino, 1887a and Protoxodon patagonensis Ameghino, 1887a. Also from the RSC, Ameghino (1885) had already founded the notoungulate Pachyrukhos moyani Ameghino, 1885 based on several specimens given to him in 1885 by Carlos Moyano, who was governor of the Territory of Santa Cruz.

In 1887, Carlos Ameghino, who was the fossil preparator of the Museo de La Plata (MLP) explored the Río Santa Cruz, as part of his first collecting trip to Patagonia on behalf of that institution (Farro, 2009; Podgorny, 2009; Fernicola, 2011a,b; Vizcaíno, 2010; Vizcaíno et al., 2012a,b, 2013). He returned with more than 2000 fossil specimens (Ameghino, 1887b; Ameghino, 1890), initially deposited at the MLP (Ameghino, 1887b; Fernicola, 2011a,b). Many of them were quickly studied and published by Florentino in a brief paper, in which he recognized 122 taxa, of which 110 were new species (Ameghino, 1887b). Among them were the astrapothere Astrapotherium patagonicum and 27 notoungulates (including 22 new species; see Appendix 1).

Two years after, and subsequent to his leaving from the MLP, F. Ameghino (1889) published "Contribución al Conocimiento de los Mamíferos Fósiles de la Argentina", in which he described and figured all known fossil mammals of Argentina, including approximately 40 astrapotheres and notoungulates from the RSC, and founded ten new notoungulate species (see Appendix 1). Among these taxa, Ameghino (1889) erected Patriarchus Ameghino, 1889 with P. palmidens Ameghino, 1889, but Fernández et al. (2019a) proved that the holotype of P. palmidens did not come from the RSC, but from the SCF in Río Bote, a western locality in the Province of Santa Cruz. Almost all of the specimens figured in Ameghino's Atlas (1889), many of which were type specimens collected by Carlos that should be housed at the MLP, remained in Florentino's private collection when he left the institution (see Fernicola, 2011a,b; Fernández et al., 2018, 2019b). Currently, the collection forms part of the Ameghino Collection housed at the Museo Argentino de Ciencias Naturales "Bernardino Rivadavia". This collection also includes specimens collected by Carlos in other exposures of the SCF, which were latter used by Florentino (Ameghino, 1891a,b,c,d, 1894, 1899) to erect almost 50 new species within Astrapotheria and Notoungulata.

Mercerat $(1890,1891)$ revised the astrapotheres and the toxodonts from the SCF housed at the MLP. He recog- 
nized two new astrapotheres from the exposures in the RSC and six from other localities (Mercerat, 1890), which were later synonymized with Astrapotherium magnum (Owen, 1853) by Ameghino (1891b) and Lydekker (1894). Within the Toxodontia, Mercerat (1891) erected almost 30 species from the RSC and nine from other exposures of the SCF. All of these species were later considered as synonyms of many of Ameghino's toxodontid nesodontines by Lydekker (1894) and, mainly, by Ameghino (1891a,b, 1894).

Santacrucian Astrapotheria and Notoungulata were revised during the beginning of the $20^{\text {th }}$ century by several American naturalists, who reduced by $\sim 5 \%$ Ameghino's (1894) Santacrucian astrapothere and notoungulate richness. Sinclair (1909) studied the Typotheria and Scott (1912, 1928, 1937) the Toxodontia and the Astrapotheria. These taxonomic revisions are currently the most accepted taxonomic schemes due to its deep analyses and the quality of the specimens studied by these authors (in person by Scott and by means of photographs by Sinclair) that were also part of the most important collections of Santacrucian ungulates. Nevertheless, as highlighted by Cassini et al. (2012) and Kay et al. (2012), of a full and exhaustive systematic revision of Santacrucian native ungulates is needed. In this context, Kramarz et al. (2019) and Seoane and Cerdeño (2019) recently studied the Astrapotheria and the hegetotheriid Typotheria, respectively, and Hernández del Pino (2018) reviewed the Toxodontia in his doctoral thesis. One of the authors of this contribution (MF) is currently reviewing the interatheriid Typotheria.

A summary of the present status of the notoungulates and astrapotheres from the RSC is given in Appendix 1.

\section{MATERIALS AND METHODS}

The new specimens studied here were collected in Barrancas Blancas (BB= Estancia Santa Lucía and Estancia Aguada Grande), Segundas Barrancas Blancas (SBB= Estancia Cordón Alto, Estancia El Tordillo and Estancia Rincón Grande) and Yaten Huageno (YH= Estancia El Refugio) (see Fernicola et al., 2014; Cuitiño et al., 2019), deposited in the Museo Regional Provincial "Padre Jesús Molina" of Río Gallegos (MPM-PV; Province of Santa Cruz). They were compared with type specimens and more complete materials from the old collections housed at the Museo Argentino de Ciencias Naturales "Bernardino Rivadavia" (MACN), Museo de La Plata (MLP), American Museum of Natural History (New York, USA), Field Museum of Natural History (Chicago, USA), and Yale Peabody Museum (New Have, USA). This contribution builds upon the taxonomic arrangements of Kramarz et al. (2019) for the astrapotheres; Scott (1912) for the toxodonts, with the exception of some species (see the systematic paleontological section); Sinclair (1909) for the interatheres, and this last author and Seoane and Cerdeño (2019) for the hegetotheres. These schemes recognize one genus (Astrapotherium Burmeister, 1879) within Astrapotheria, and nine genera within Notoungulata: Nesodon Owen, 1846; Homalodotherium Flower, 1873; Pachyrukhos Ameghino, 1885; Protypotherium Ameghino, 1885; Interatherium Ameghino, 1887a; Adinotherium Ameghino, 1887b; Phobereotherium Ameghino, 1887b; Hyperoxotodon (Ameghino, 1887b) and Hegetotherium Ameghino, 1887b. In the case of Phobereotherium (with P. silvaticum Ameghino, 1887b), it is not included in the present analysis because its status is considered here as doubtful. Unfortunately, the type specimen of $P$. silvaticum is lost and there is no other recognized material in the MACN and MLP, so its diagnostic features could not be directly evaluated. There is a photograph of an assigned juvenile specimen (Vizcaíno et al., 2017, Suppl. files, Appendix 1, p. 139, fig. 343; p. 140, figs. 344, 467) that exhibits a poorly preserved premaxilla. The incisor region is broken and the photograph is not clear enough to establish the absence of the median incisors, which is the diagnostic feature used to distinguish the genus and species; moreover, the lack of a scale in the photograph do not allow us to compare the length of P3-M3 with the one given for the species by Ameghino (1887b).

Institutional abbreviations. MACN, Museo Argentino de Ciencias Naturales "Bernardino Rivadavia", Ciudad Autónoma de Buenos Aires, Argentina; MACN-A, Colección Nacional Ameghino at the MACN, Ciudad Autónoma de Buenos Aires, Argentina; MPM-PV, Colección Paleontología de Vertebrados at the Museo Padre Molina, Santa Cruz, Argentina.

Anatomical abbreviations. C/c, upper/lower canine; I/i, upper/ lower incisor; M/m, upper/lower molar; P/p, upper/lower premolar. 
Other abbreviations. L, length; LLL, labio-lingual length of the teeth; MDL, mesio-distal length of the teeth; SALMA, South America Land Mammal Age.

\section{SYSTEMATIC PALEONTOLOGY}

\author{
Class Mammalia Linnaeus, 1758 \\ Order AstRAPOTHERIA Lydekker, 1894 \\ Family AstrapotheriIdae Ameghino, 1887 \\ Subfamily Astrapotherinan Ameghino, 1887
}

Genus Astrapotherium Burmeister, 1879

Type species. Astrapotherium magnum (Owen, 1853). Santa Cruz Formation, Barrancas del Río Santa Cruz, Province of Santa Cruz, Argentina.

Species recognized in the Santa Cruz Formation. The type and A. burmeisteri Mercerat, 1890.

Comments. Following Kramarz et al. (2019), A. magnum is the smallest species and $A$. burmeisteri could reach up to $20 \%$ of the former's length.

\section{Astrapotherium magnum}

Figure 3.1

Referred material. MPM-PV 19927, left mandibular fragment with m1-2, talonid of right $\mathrm{m} 2$, and broken tusk, all from the same individual (see Appendix 2).

Geographic distribution. YH (Estancia El Refugio).

Stratigraphic distribution. Santa Cruz Formation (Early-Middle Miocene).

Comments. MPM-PV 19927 has an $\mathrm{m} 1$ and $\mathrm{m} 2$ with the Hunter-Schreger enamel bands; there is a well-developed (but broken) isolated tusk-like canine. The specific identification of MPM-PV 19927 is associated to its size $\left(\mathrm{MDL}_{\mathrm{m} 1} \approx\right.$ $3.9 \mathrm{~cm}, \mathrm{LLL}_{\mathrm{m} 1}=2.1 \mathrm{~cm} ; \mathrm{MDL}_{\mathrm{m} 2}=4.8 \mathrm{~cm}, \mathrm{LLL}_{\mathrm{m} 2}=2.4 \mathrm{~cm}$ ) because its dimension falls within the range of measurements given by Scott (1928) and Kramarz et al. (2019) for $A$. magnum $\left(\mathrm{MDL}_{\mathrm{m} 1} \approx 3.5-5.0 \mathrm{~cm}, \mathrm{LLL}_{\mathrm{m} 1} \approx 2.0-3.0 \mathrm{~cm} ; \mathrm{MDL}_{\mathrm{m} 2} \approx\right.$ $\left.4.8-6.2 \mathrm{~cm}, \mathrm{LLL}_{\mathrm{m} 2} \approx 2.2-3.4 \mathrm{~cm}\right)$.

\section{Astrapotherium sp.}

Referred material. See Appendix 2.
Geographic distribution. BB (Estancia Aguada Grande and Estancia Santa Lucia) and SBB (Estancia Cordón Alto and Estancia El Tordillo).

Stratigraphic distribution. Santa Cruz Formation (Early-Middle Miocene).

Comments. The referred materials are very fragmentary in order to establish a specific identification.

Order NotOUngulata Roth, 1903

Suborder ToxodontIA Owen, 1853

Family HomalodotherIIDAE (Ameghino, 1889) Gregory, 1910

\section{Genus Homalodotherium Flower, 1873}

Type species. Homalodotherium cunninghami Flower, 1873. Santa Cruz Formation, Río Gallegos, Province of Santa Cruz, Argentina.

Species recognized in the Santa Cruz Formation. The type, $H$. segoviae Ameghino, 1891a (with reservations; see Scott, 1912), H. excursum Ameghino, 1894 and H. crassum Ameghino, 1894.

Comments. Scott (1912) contrasted $H$. cunninghami and $H$. segoviae by the presence of smaller incisors, reduced $\mathrm{P} 1$, and a narrower muzzle in the latter. The remaining species of Homalodotherium, H. crassum and $H$. excursum, only known by a few postcranial remains - astragalus and tibia, and foot-bones, respectively - were differentiated by Scott (1912) by their size, $H$. crassum being the largest and $H$. excursum, the smallest.

\section{Homalodotherium sp.}

Figure 3.2-3

Referred material. See Appendix 2.

Geographic distribution. BB (Estancia Santa Lucia) and SBB (Estancia Cordón Alto).

Stratigraphic distribution. Santa Cruz Formation (Early-Middle Miocene).

Description and comments. The cheek teeth of the referred specimens exhibit roots and labial and lingual cingula, features that, among others, characterize Homalodotherium. Their size resembles that of both $H$. cunninghami and $H$. segoviae, but a further specific taxonomic identification was not possible due to the fragmentary condition of the speci- 
mens that do not allow us to evaluate the differential development of upper incisors and P1.

Family ToxodontidAe Owen, 1845

Subfamily Nesodontinae Murray, 1866
Genus Nesodon Owen, 1847

Type species. Nesodon imbricatus Owen, 1847. Santa Cruz Formation, Río Gallegos, Province of Santa Cruz, Argentina.

Species recognized in the Santa Cruz Formation. The type species, N. conspurcatus (Ameghino, 1887b) and N. cornutus Scott, 1912.

(1)

(2)
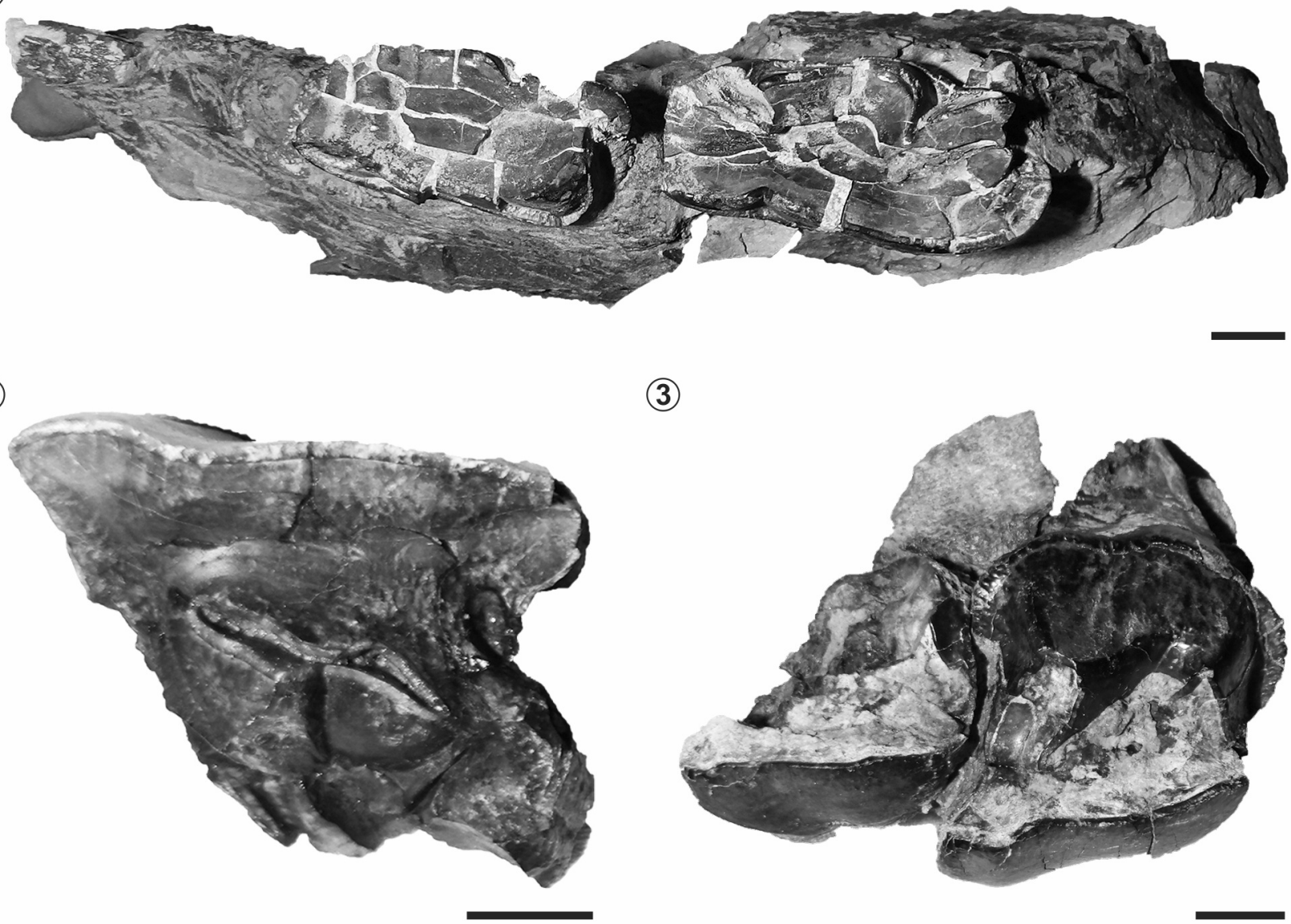

(3)

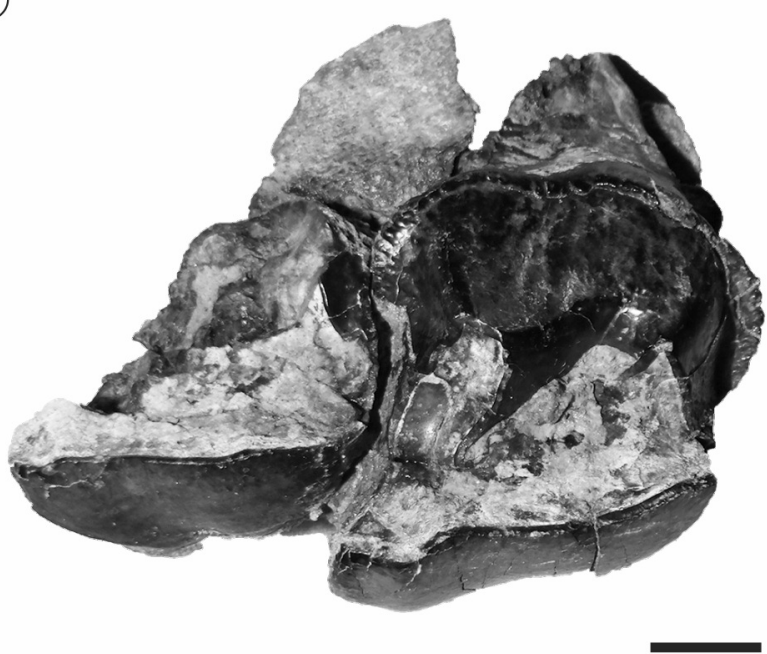

(4)

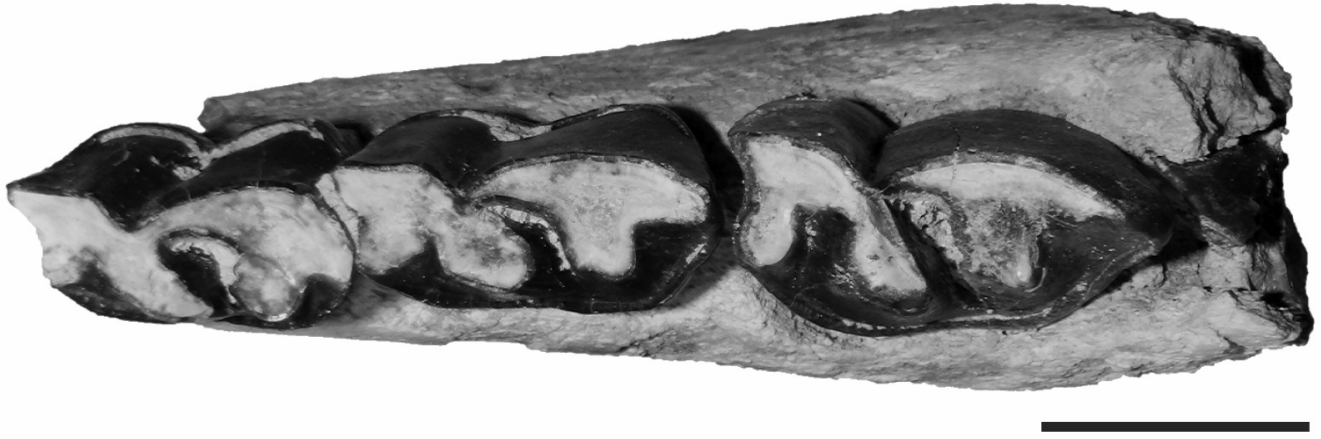

Figure 3. In oclusal view. 1, Astrapotherium magnum, left mandibular fragment with m1-2 of MPM-PV 19927; 2-4, Homalodotherium sp., 2, broken left M3 of MPM-PV 19629; 3, MPM-PV 19802, right maxillary fragment with P4-M1?; 4, right mandibular fragment with p4-m2 of MPM-PV 19725. Scale bars= $10 \mathrm{~mm}$. 
Comments. According to Scott (1912), N. imbricatus is the largest species, whereas $N$. conspurcatus is the smallest (at least $15 \%$ smaller than $N$. imbricatus). Nesodon cornutus, only known by its holotype, exhibits an intermediate size and is characterized by a higher cranium, a higher sagittal crest and the presence of a bulge in the frontal bone located in front of the temporal lines, probably associated to a dermal horn (Scott, 1912; Croft et al., 2003).

\section{Nesodon imbricatus Owen, 1847}

Figure 4.1-2; Appendix 3; Table 1

Referred material. MPM-PV 19560, almost complete mandible and lower dentition.

Geographic distribution. BB (Estancia Santa Lucia).

Stratigraphic distribution. Santa Cruz Formation (Early-Middle Miocene).

Description and comments. MPM-PV 19560 is assigned to Nesodon imbricatus due its morphology (e.g., well-developed p1) and its size $\left(M L_{m 1}=31.0 \mathrm{~mm} ; L_{L L}=17.8 \mathrm{~mm}\right.$; see Appendix 3 for the remaining teeth), which falls within the range established by Scott (1912) for the species (e.g., $\mathrm{MDL}_{\mathrm{m} 1} \approx 25.0-35.0 \mathrm{~mm} ; \mathrm{LLL}_{\mathrm{m} 1} \approx 15.0-20.0 \mathrm{~mm}$ ).

\section{Nesodon sp.}

Figure 4.3

Referred material. See Appendix 2.

Geographic distribution. BB (Estancia Santa Lucia) and SBB (Estancia Cordón Alto).

Stratigraphic distribution. Santa Cruz Formation (Early-Middle Miocene).

Comments. Mostly all of the assigned specimens are fragments of upper and lower cheek teeth in different ontogenetic stages, but its fragmentary nature does not allow a determination below the genus level.

\section{Genus Adinotherium Ameghino, 1887b}

Type species. Adinotherium magister Ameghino, 1887b. Santa Cruz Formation, Barrancas del Río Santa Cruz, Province of Santa Cruz, Argentina.

Species recognized in the Santa Cruz Formation. A. ovinum (Owen, 1853), A. nitidum Ameghino, 1887b, A. splendidum
Ameghino, 1887b, A. robustum Ameghino, 1891a and $A$. karaikense Ameghino, 1891c.

Comments. Scott (1912) used A. ovinum to characterize the genus, and differentiated $A$. splendidum by its high cranium and the presence of extremely broad and massive postorbital processes, which exhibit an unusual anterior position. Scott (1912) validated $A$. robustum with reservations and described the species as being the largest and heaviest species, which presents a protuberance on the occipital region due to the development of the epitympanic sinus, greatly expanded zygomatic arches and a well-developed sagittal crest that is markedly high and descends quite abruptly to the forehead. Scott (1912) differentiated A. nitidum by its size mentioning that it was the smallest Adinotherium, but, as recognized by the author, the species was erected based on a juvenile specimen, a reason why A. nitidium is not included in our analysis. A. karaikense is only known from its type specimen that is currently lost in the collection at MACN-A, it is characterized by its long and narrow skull, anteriorly narrow rostrum and the presence of a slight curvature of the zygomatic arches. Fortunately, there there is a photograph of this skull in Scott's album in Vizcaíno et al. (2017, Suppl. files, Appendix 1, p. 137, fig. 461), a fact that allowed us to question the diagnostic characteristics mentioned by Scott (1912), because the zygomatic arches are not preserved in the type and the narrowing of the rostrum falls within the range observed in specimens of Adinotherium ovinum (M. Fernández pers. obs.). For this reason, $A$. karaikense is also omitted from the present analysis.

Adinotherium ovinum (Owen, 1853)

Figure 5.1-2; Appendix 3; Tables 2-3

Referred material. MPM-PV 19717, almost complete skull with associated dentition.

Geographic distribution. SBB (Estancia Cordón Alto). Stratigraphic distribution. Santa Cruz Formation (Early-Middle Miocene).

Description and comments. MPM-PV 19717 is a well-preserved skull of a young adult which features that allows its identification as Adinotherium (e.g., reduced I3, C and P1; I12 more transversely positioned than in Nesodon; presence of a conspicuous narrowing of the skull at the level of the 
(1)

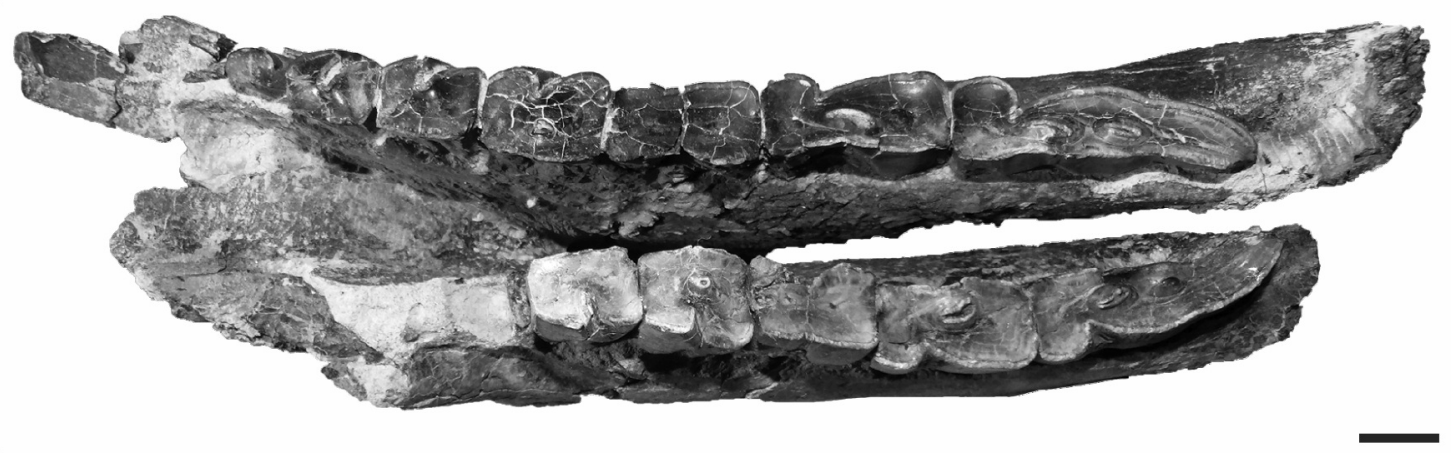

(2)

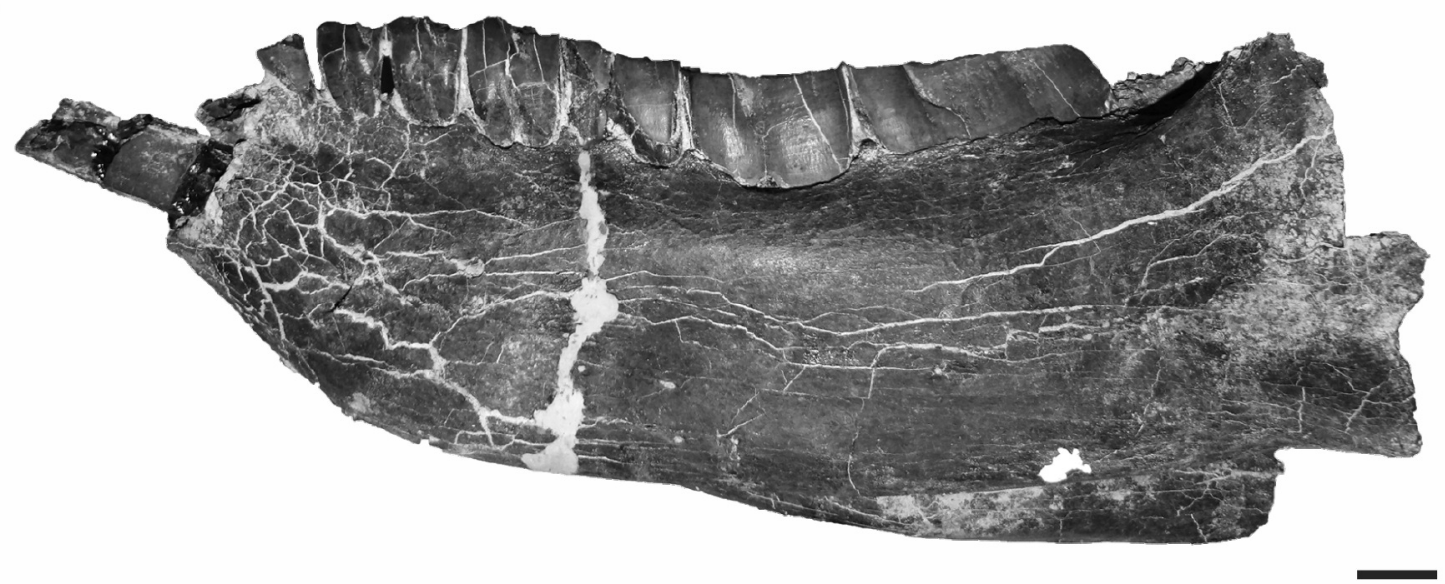

(3)

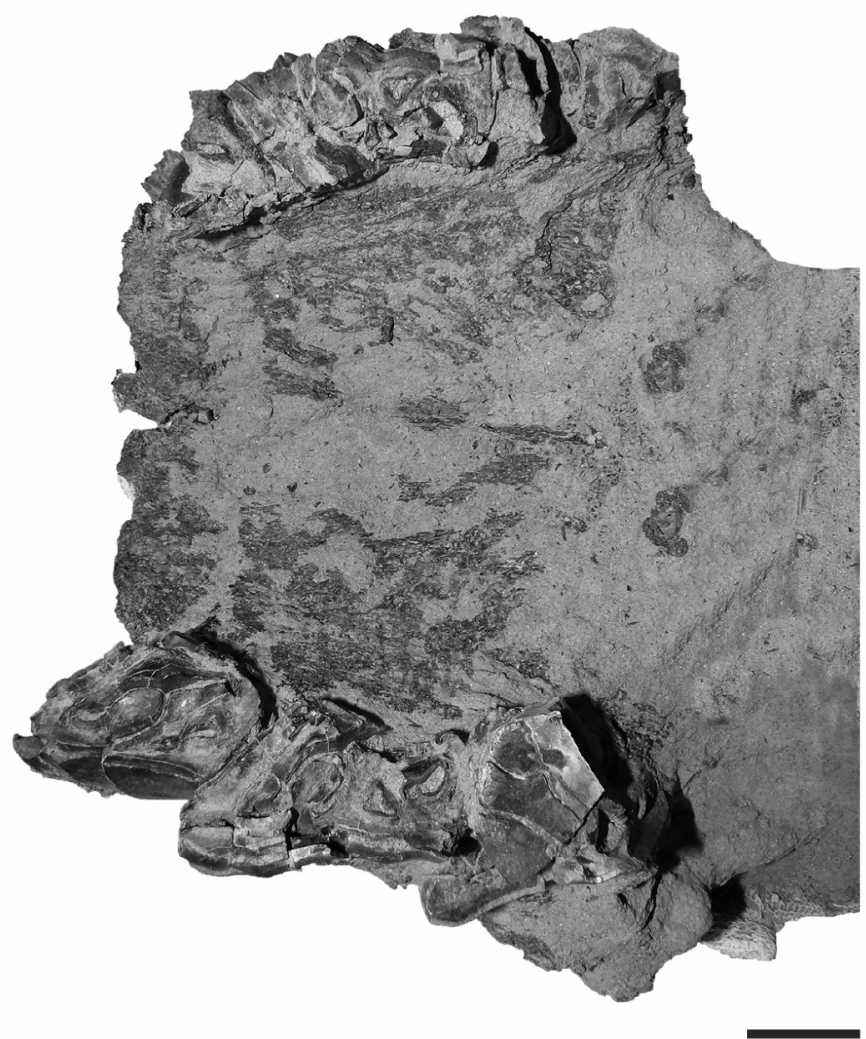

Figure 4. Nesodon. 1-2, N. imbricatus, MPM-PV 19560, almost complete mandible with its dentition; 1, oclusal view; 2, right lateral view (reversed); 3, Nesodon sp., MPM-PV 19568, maxillary fragment with both broken M1-3, oclusal view; Scale bars= $20 \mathrm{~mm}$. 
premaxillary-maxillary suture). Regarding the allocation to A. ovinum, the postorbital processes, which are incomplete, do not show the conspicuous development described for A. splendidum and both are located posterior to the level of $\mathrm{M} 3$, in contrast to the unusually anterior position of $A$. splendidum (Scott, 1912). The sagittal crest is long and with a similar height throughout its length, the zygomatic arches are well-developed, but not massive nor greatly expanded as described for A. robustus (Scott, 1912). In addition, the skull does not exhibit the large size nor the robustness described for the last species.

\section{Adinotherium sp.}

Referred material. See Appendix 2.

Geographic distribution. BB (Estancia Aguada Grande and Estancia Santa Lucia), SBB (Estancia Cordón Alto) and YH.

Stratigraphic distribution. Santa Cruz Formation (Early-Middle Miocene).

Comments. All the referred specimens involve fragments of upper and lower cheek teeth in different ontogenetic stages, which are too incomplete to establish the species.

Suborder TYPOTHERIA Zittel, 1893

Family Hegetotheri Idae Ameghino, 1894

Subfamily Hegetotheriınae Ameghino, 1894

Genus Hegetotherium Ameghino, 1887b

Type species. Hegetotherium mirabile Ameghino, 1887b. Santa Cruz Formation, Barrancas del Río Santa Cruz, Province of Santa Cruz, Argentina.

Species recognized in the Santa Cruz Formation. The type species according to Seoane and Cerdeño (2019).

Hegetotherium mirabile Ameghino, 1887b

Figure 6.1-4; Appendix 3; Tables 4-5

Referred material. See Appendix 2.

Geographic distribution. BB (Estancia Aguada Grande and Estancia Santa Lucia) and SBB (Estancia Cordón Alto).

Stratigraphic distribution. Santa Cruz Formation (Early-Middle Miocene).

Description and comments. All the referred specimens in- volve euhypsodont cheek teeth, which identification as Hegetotherium mirabile is associated to both its morphology (e.g., upper teeth sub-elliptical in outline, with simple oclusal surfaces that lack fossettes and prominent folds; lower cheek teeth with straight lingual faces and prominent labial sulci) and size (e.g., $\mathrm{MDL}_{\mathrm{M} 1} \approx 7.5-8.0 \mathrm{~mm}, \mathrm{LLL}_{\mathrm{M} 1} \approx 4.0-$ $4.5 \mathrm{~mm} ; \mathrm{MDL}_{\mathrm{m} 1} \approx 6.0-7.0 \mathrm{~mm}, \mathrm{LLL}_{\mathrm{m} 1} \approx 3.0-4.0 \mathrm{~mm}$; see Appendix 3, Tables 4-5 for other dimensions) that falls within the range given by Sinclair (1909) and Seoane and Cerdeño (2019) for the species (e.g., $\mathrm{MDL}_{\mathrm{M} 1} \geq 7 \mathrm{~mm}, \mathrm{LLL}_{\mathrm{M} 1}$ $\geq 3.8 \mathrm{~mm} ; \mathrm{MDL}_{\mathrm{m} 1} \geq 5 \mathrm{~mm}, \mathrm{LLL}_{\mathrm{m} 1}$ is $\geq 3 \mathrm{~mm}$ ).

\section{Genus Pachyrukhos Ameghino, 1885}

Type species. Pachyrukhos moyani Ameghino, 1885. Santa Cruz Formation, Barrancas del Río Santa Cruz, Province of Santa Cruz, Argentina.

Species recognized in the Santa Cruz Formation. The type species according to Seoane and Cerdeño (2019).

Pachyrukhos moyani Ameghino, 1885

Figure 6.5-8; Appendix 3; Tables 6-7

Referred material. See Appendix 2.

Geographic distribution. SBB (Estancia Cordón Alto and Estancia El Tordillo).

Stratigraphic distribution. Santa Cruz Formation (Early-Middle Miocene).

Description and comments. The referred specimens involve incomplete skulls and maxillary and mandibular fragments for which the identification as Pachyrukhos moyani is related to both its morphology (e.g., rodent-like skulls with lower rostrum; absence of $12-\mathrm{P} 1$ that is replaced in a conspicuous upper diastema; upper teeth sub-elliptical in outline without fossettes and marked folds; i3-p1 absent and replaced by a pronounced lower diastema; lower cheek teeth with straight lingual faces and conspicuous labial sulci) and small size compared with other typotheres (e.g., $\mathrm{MDL}_{\mathrm{M} 1} \approx 4.0-4.6$ $\mathrm{mm}, \mathrm{LLL}_{\mathrm{M} 1} \approx 2.5-3.5 \mathrm{~mm} ; \mathrm{MDL}_{\mathrm{m} 1} \approx 3.0-4.0 \mathrm{~mm}, \mathrm{LLL}_{\mathrm{m} 1} \approx$ 2.0-2.5 mm; see Appendix 3, Tables 6-7 for other dimensions) that falls within the range of measurements given by Sinclair (1909) and Seoane and Cerdeño (2019) for the species (e.g., $\mathrm{MDL}_{\mathrm{M} 1} \approx 4.0-5.2 \mathrm{~mm}, \mathrm{LLL}_{\mathrm{M} 1} \approx 2.5-3.5 \mathrm{~mm}$; $\mathrm{MDL}_{\mathrm{m} 1} \approx 3.5-4.6 \mathrm{~mm}, \mathrm{LLL}_{\mathrm{m} 1} \approx 1.8-2.5 \mathrm{~mm}$ ). 
(1)

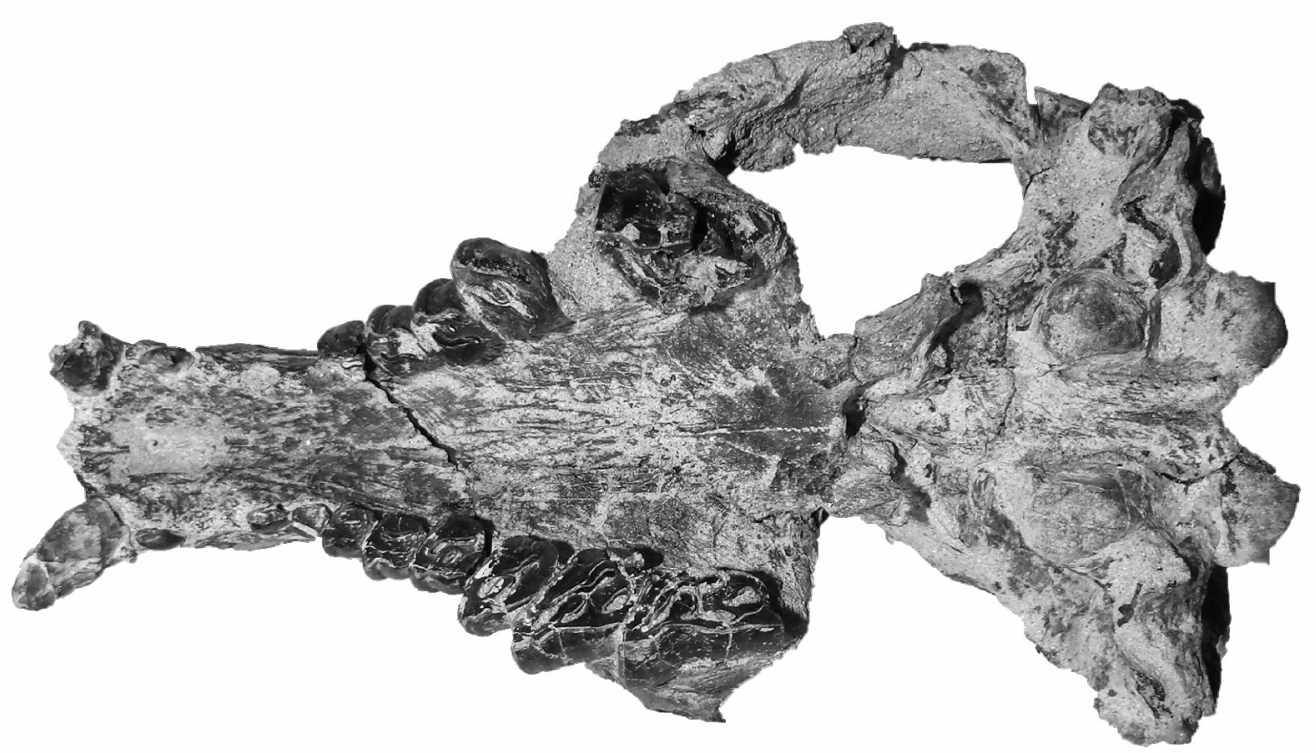

(2)

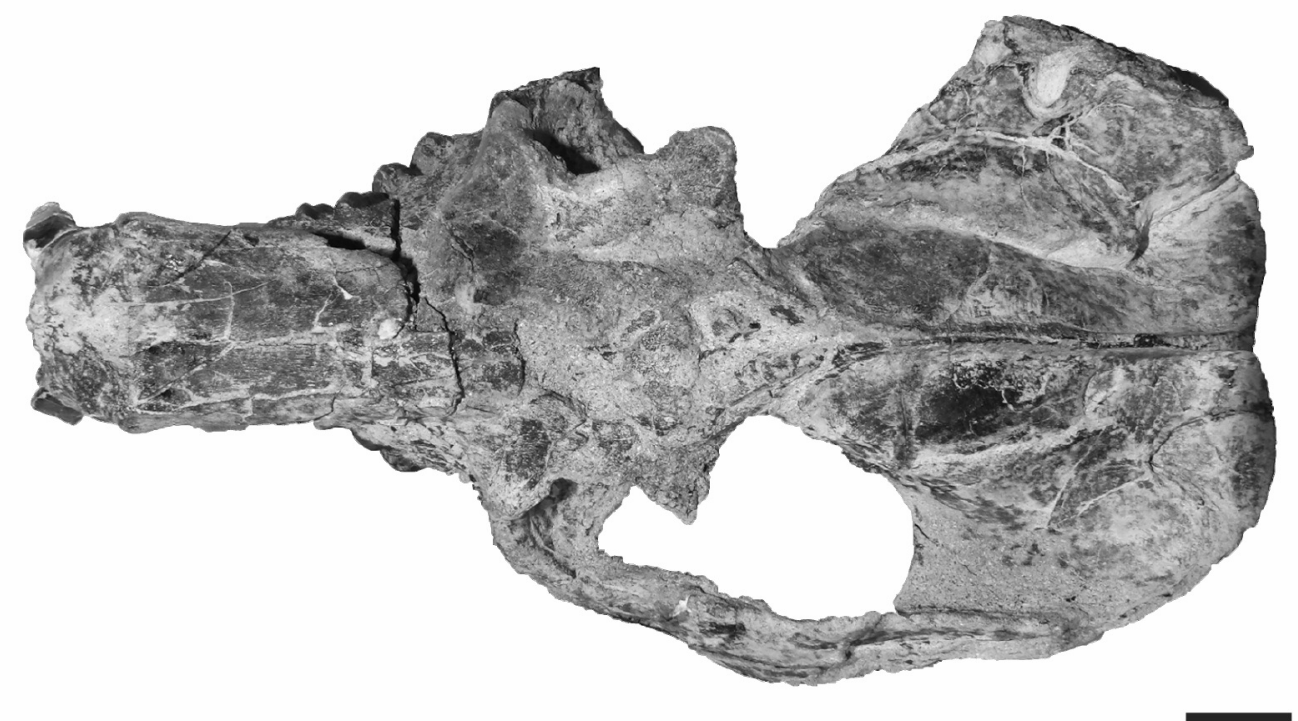

(3)

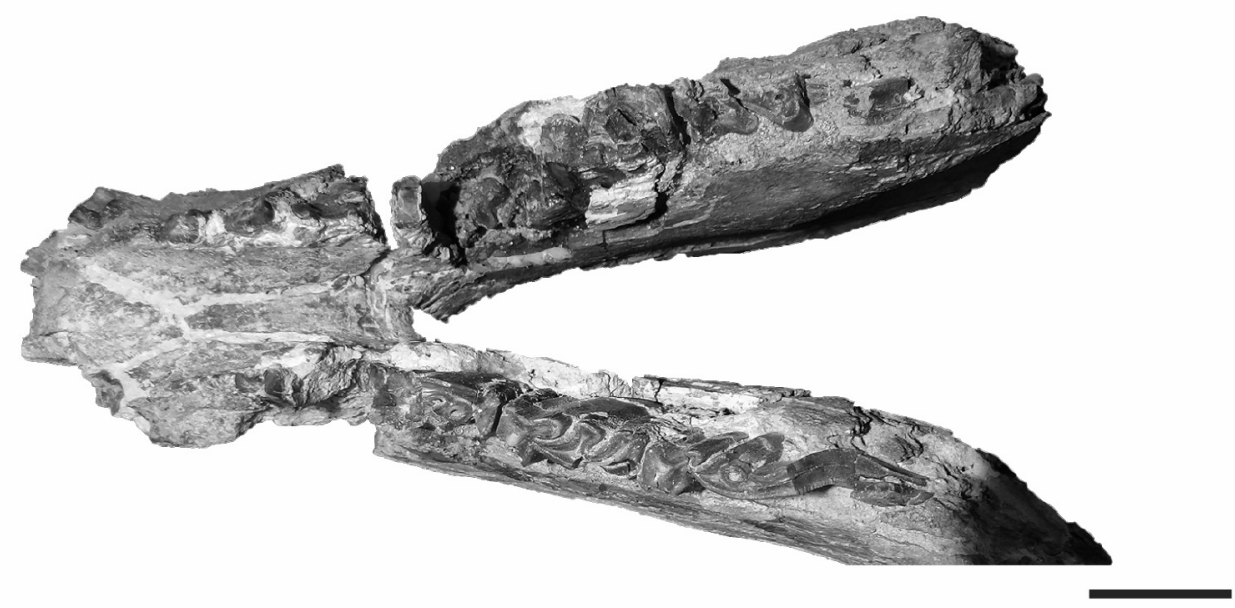

Figure 5. Adinotherium. 1-2, A. ovinum, MPM-PV 19717, almost complete skull with associated dentition; 1, ventral view; 2, dorsal view; 3, Adinotherium sp., MPM-PV 19567, incomplete mandible with associated broken dentition, oclusal view. Scale bars= $20 \mathrm{~mm}$. 
Family INTERATHERIIDAE Ameghino, 1887a

Subfamily INTERATHERIInAe Ameghino, 1887a

Genus Protypotherium Ameghino, 1885

Type species. Protypotherium antiquum Ameghino, 1885. Formación Ituzaingó, Barrancas del Río Paraná, Province of Entre Ríos, Argentina.

Species recognized in the Santa Cruz Formation. Protypotherium australe Ameghino, 1887a, Protypotherium praerutilum Ameghino, 1887b, and Protypotherium attenuatum Ameghino, 1887b.

Comments. Protypotherium presents continuous and complete dental series, I1-C mesiodistally expanded, labiolingually compressed and equally developed; P/p2-4 not molarized; P2-4 sub-triangular in outline and with shallow lingual and labial folds; M1-3 with deep and long entoflexus and very shallow -or even absent-parastilar sulcus and ectoflexus; bifid i1-2, with a cylindrical section shape; i3-c mesiodistally expanded with lingual sulcus, and p1 completely caniniform with no differentiated talonid; p3-4 with the trigonid larger than the talonid, with the opposite condition observed in the molars. Within the species of Protypotherium validated by Sinclair (1909), P. australe is characterized by its wider molars and larger size; $P$. praerutilum by its relatively narrower molars and intermediate size (at least $15 \%$ smaller than $P$. australe; Sinclair, 1909), and $P$. attenuatum distinguished only by its smaller size (30\% smaller than P. australe; Sinclair, 1909). Tauber
(1)

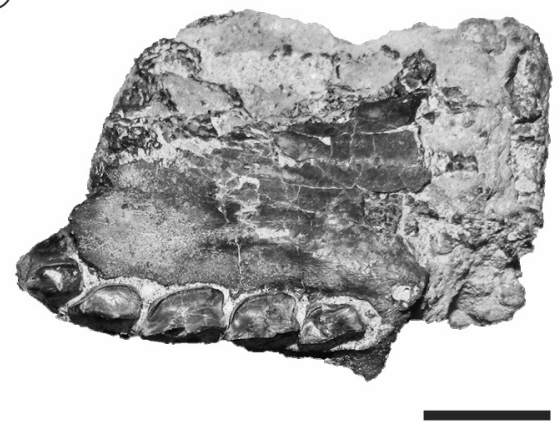

(5)

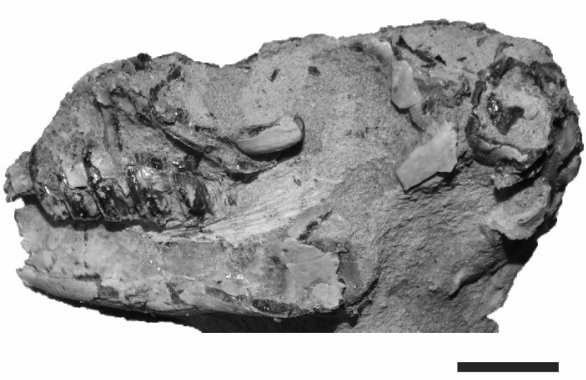

(2)

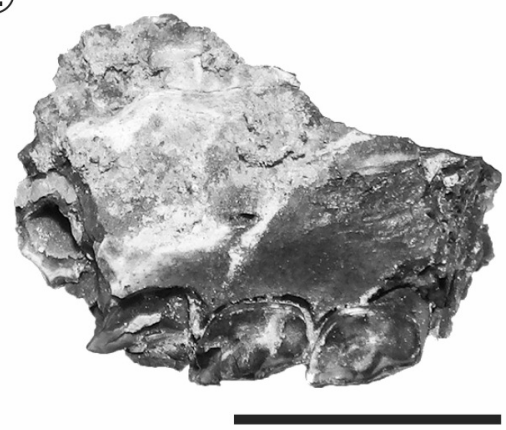

(6)

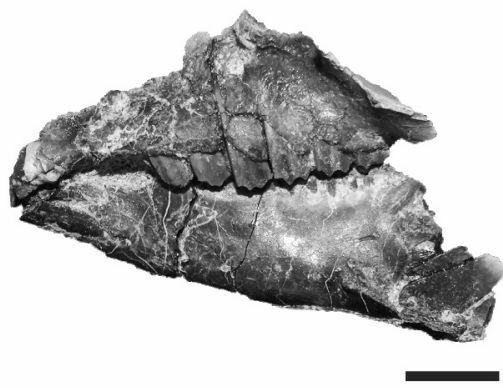

(3)

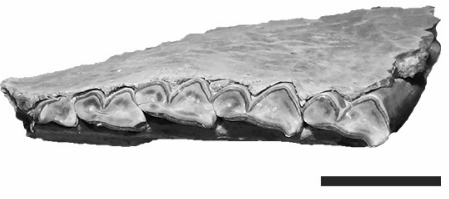

(4)

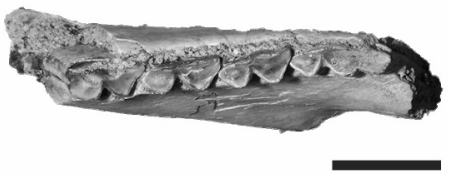

(7)

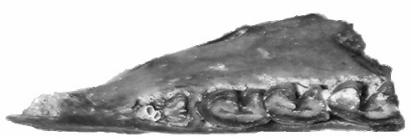

(8)

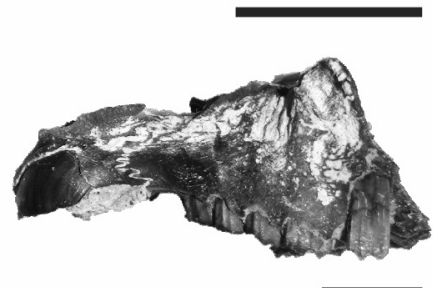

Figure 6. Hegetotheriidae. 1-4, Hegetotherium mirabile; 1, MPM-PV 19513, right maxillary fragment with P3 (erupting)-M3, oclusal view; 2, MPM-PV 19626, right maxillary fragment with broken P2 (alveolus)-4 and M1, oclusal view; 3, MPM-PV 19487, right mandibular fragment with p2-m2, oclusal view, oclusal view; 4, MPM-PV 19658, left mandibular fragment with p4-m3, oclusal view; 5-8, Pachyrukhos moyani; 5, MPM-PV 19800, articulated incomplete skull and mandible, left lateral view; 6, MPM-PV 19905, articulated incomplete skull and mandible, left lateral view; 7, MPM-PV 19917, right mandibular fragment with p2-m1, oclusal view; 8, MPM-PV 19917, incomplete skull, right lateral view (reversed). Scale bars $=10 \mathrm{~mm}$. 
(1996) supported this taxonomic arrangement and emended their diagnoses; nevertheless, a preliminary analysis developed in the doctoral thesis in progress of one of the authors (MF) indicates that some characteristics mentioned by Tauber (1996) are variable, reason why we focus mainly on Sinclair (1909), particularly on the size, in order to establish the specific determination.

\section{Protypotherium australe Ameghino, 1887a}

Figure 7.1-4; Appendix 3; Tables 8-9

Referred material. See Appendix 2.

Geographic distribution. BB (Estancia Santa Lucia) and SBB (Estancia Cordón Alto and Estancia El Tordillo).

Stratigraphic distribution. Santa Cruz Formation (Early-Middle Miocene).

Description and comments. The identification as $P$. australe is related to both its morphology (e.g., 11 is highly curved and well expanded and cheek teeth are generally wider than those observed in $P$. praerutilum and $P$. attenuatum) and, particularly, its size (e.g., $\mathrm{MDL}_{\mathrm{M} 1} \approx 7.0-9.5 \mathrm{~mm}, \mathrm{LLL}_{\mathrm{M} 1} \approx 4.0-$ $6.5 \mathrm{~mm} ; \mathrm{MDL}_{\mathrm{m} 1} \approx 7.0-9.0 \mathrm{~mm}, \mathrm{LLL}_{\mathrm{m} 1} \approx 4.0-5.0 \mathrm{~mm}$; see Appendix 3, Tables 8-9 for other dimensions) that fall within the range of size mentioned by Sinclair (1909) for this species (e.g., $\mathrm{MDL}_{\mathrm{M} 1} \approx 7.0-9.0 \mathrm{~mm}, \mathrm{LLL}_{\mathrm{M} 1} \approx 5.0-6.0 \mathrm{~mm}$; $\mathrm{MDL}_{\mathrm{m} 1} \approx 7.0-9.0 \mathrm{~mm}, \mathrm{LLL}_{\mathrm{m} 1} \approx 3.5-4.5 \mathrm{~mm}$ ).

\section{Protypotherium praerutilum Ameghino, 1887b}

Figure 7.5-6; Appendix 3; Tables 10-11

\section{Referred material. See Appendix 2.}

Geographic distribution in Río Santa Cruz. BB (Estancia Aguada Grande and Estancia Santa Lucia) and SBB (Estancia Cordón Alto and Estancia El Tordillo).

Stratigraphic distribution. Santa Cruz Formation (Early-Middle Miocene).

Description and comments. The identification as $P$. praerutilum is based on its teeth morphology (e.g., upper incisors sub-equally developed and cheek teeth narrower than in P. australe; m3 lacks of labial sulcus in the talonid as observed in the holotype MACN-A 1082 that is present on $P$. australe and $P$. attenuatum) and teeth size (e.g., $\mathrm{MDL}_{\mathrm{M} 1} \approx$ 6.3-6.7 mm, $\mathrm{LLL}_{\mathrm{M} 1} \approx 4.5 \mathrm{~mm} ; \mathrm{MDL}_{\mathrm{m} 1} \approx 6.0-6.5 \mathrm{~mm}, \mathrm{LLL}_{\mathrm{m} 1} \approx$
3.0-3.5 mm; see Appendix 3, Tables 10-11 for other dimensions) that matches the range of dimensions given by Sinclair (1909) for the species (e.g., $\mathrm{MDL}_{\mathrm{M} 1} \approx 6.2-6.6 \mathrm{~mm}$, $\mathrm{LLL}_{\mathrm{M} 1} \approx 4.5 \mathrm{~mm} ; \mathrm{MDL}_{\mathrm{m} 1} \approx 6.0 \mathrm{~mm}, \mathrm{LLL}_{\mathrm{m} 1} \approx 3.0 \mathrm{~mm}$ ).

\section{Protypotherium attenuatum Ameghino, 1887b}

Figure 7.7-8; Appendix 3; Tables 12-13

\section{Referred material. See Appendix 2.}

Geographic distribution. BB (Estancia Aguada Grande and Estancia Santa Lucia) and SBB (Estancia Cordón Alto and Estancia El Tordillo).

Stratigraphic distribution. Santa Cruz Formation (Early-Middle Miocene).

Description and comments. The assignation to P. attenuatum is based on both its teeth morphology (e.g., more pronounced curvature on the upper cheek tooth row as seen in the syntype MACN-A 524 compared with $P$. australe and $P$. praerutilum) and its teeth size (e.g., $\mathrm{MDL}_{\mathrm{M} 1} \approx 6.0-6.2 \mathrm{~mm}$, $\mathrm{LLL}_{\mathrm{M} 1} \approx 4.0 \mathrm{~mm} ; \mathrm{MDL}_{\mathrm{m} 1} \approx 4.5-6.0 \mathrm{~mm}, \mathrm{LLL}_{\mathrm{m} 1} \approx 2.0-3.0 \mathrm{~mm}$; see Appendix 3, Tables 12-13 for other dimensions) that falls within the range of size mentioned by Sinclair (1909) for the species (e.g., $\mathrm{MDL}_{\mathrm{M} 1} \leq 6.2 \mathrm{~mm}, \mathrm{LLL}_{\mathrm{M} 1} \approx 4.5 \mathrm{~mm}$; $\mathrm{MDL}_{\mathrm{m} 1} \approx 5.0-5.5 \mathrm{~mm}, \mathrm{LLL}_{\mathrm{m} 1} \leq 3.0 \mathrm{~mm}$ ).

\section{Protypotherium sp.}

Referred material. See Appendix 2.

Geographic distribution. BB (Estancia Santa Lucia) and SBB (Estancia Cordón Alto and Estancia El Tordillo).

Stratigraphic distribution. Santa Cruz Formation (Early-Middle Miocene).

Comments. All the referred specimens are too fragmented in order to establish a specific identification.

Genus Interatherium Ameghino, 1887a

Type species. Interatherium rodens Ameghino, 1887a. Santa Cruz Formation, Barrancas del Río Santa Cruz, Province of Santa Cruz, Argentina.

Species recognized in the Santa Cruz Formation. The type species, Interatherium extensum Ameghino, 1889, I. excavatum Ameghino, 1889 and I. robustum Ameghino, 1891a.

Comments. Interatherium is characterized, among other fea- 
tures, by exhibiting a well-developed descending maxillary process of the zygomatic arch; 11 more developed than 12$C$, with the latter two reduced or even missing; P/p3-4 completely molarized; P3-4 sub-rectangular in outline; M1-3 with deep and continuous entoflexus and parastylar sulcus, with well-developed folds, but less than the pre-
(1)

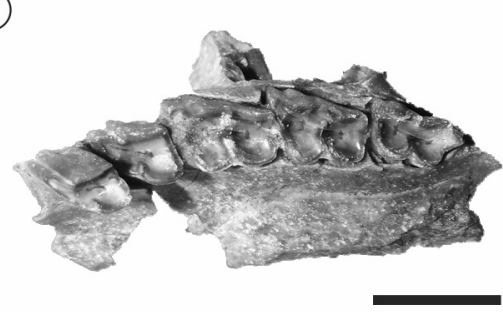

(4)

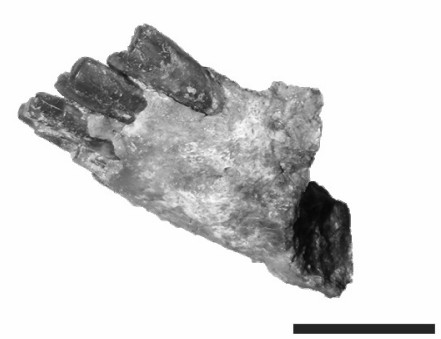

(7)

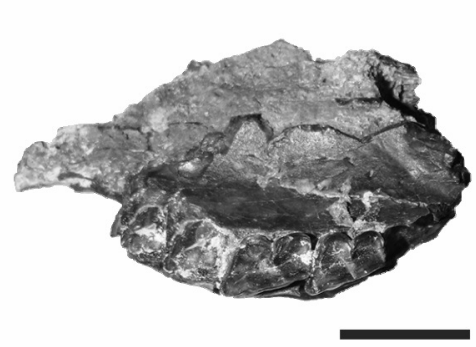

(8)

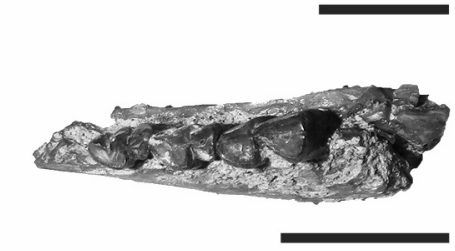

(9)

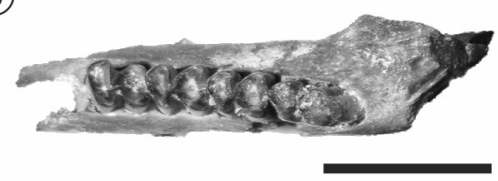

(2)

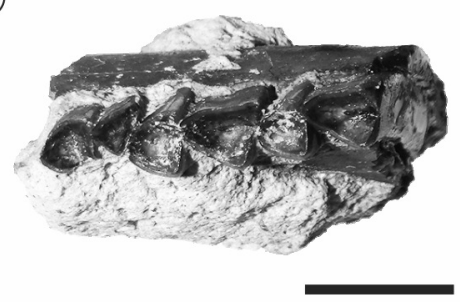

(5)

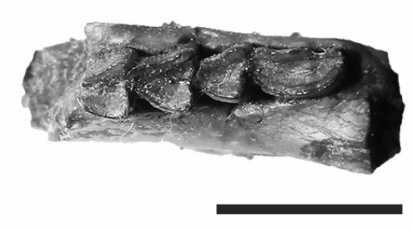

(10)
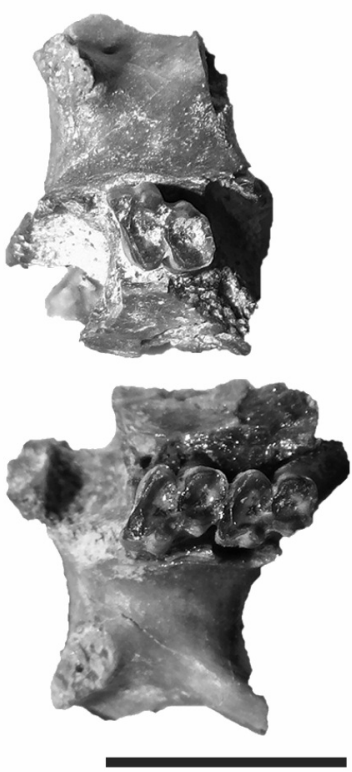

(3)

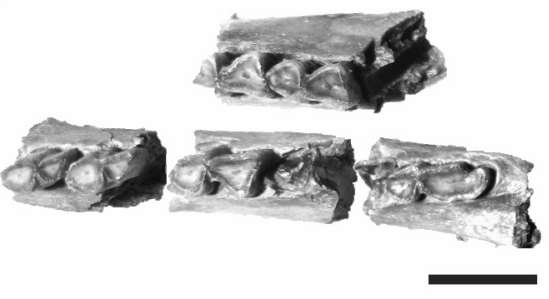

(6)

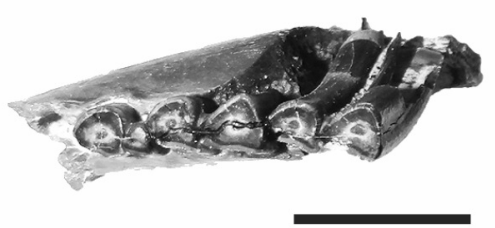

(11)

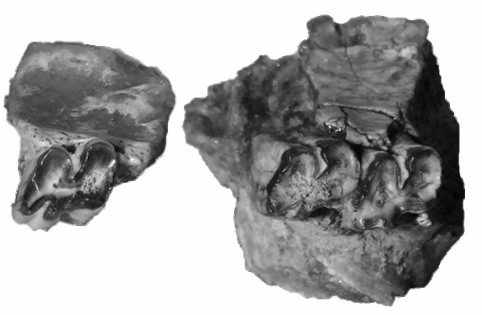

(12)

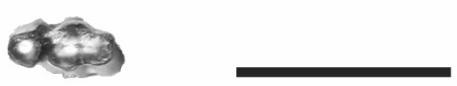

(13)

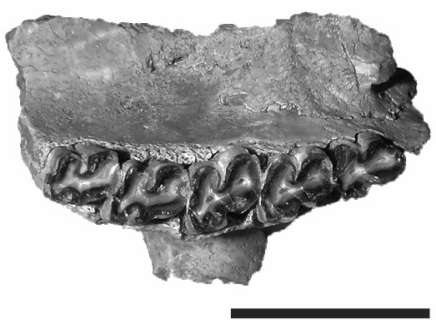

Figure 7. Interatheriinae. 1-4, Protypotherium australe; 1-3, MPM-PV 19921; 1, left maxillary fragment with P3-M3, oclusal view; 2, right mandibular fragment with $\mathrm{m} 1$ (broken) -2 (above) and left mandibular fragments with $\mathrm{p3}-\mathrm{m} 2$ (trigonid) -3 (below), oclusal view; 3, mandibular symphysis, right lateral view (reversed); 4, MPM-PV 19925, left mandibular fragment with p4-m2, oclusal view; 5-6, Protypotherium praerutilum; 5, MPM-PV 19911, left mandibular fragment with m2-3, oclusal view; 6, MPM-PV 19526, right mandibular fragment with p4$\mathrm{m} 2$, oclusal view; 7-8, Protypotherium attenuatum; 7, MPM-PV 19534, right maxillary fragment with alveoli of P3-4 and complete M1-2, oclusal view; 8, MPM-PV 19525, left mandibular fragment with p3-m1, oclusal view; 9-13, Interatherium sp.; 9, right mandibular fragment with dp4-m3 of MPM-PV 19770, oclusal view; 10, fragmented palate with left M1 and right M1-2 of MPM-PV 19770, oclusal view; 11, fragmented maxilla with right P4 (isolated) and M1-2 of MPM-PV 19729, oclusal view; 12, left m3 of MPM-PV 19729, oclusal view; 13, MPM-PV 19825, right maxillary fragment with P3-M3, oclusal view. Scale bars= $10 \mathrm{~mm}$. 
molars; i1-p1 slightly mesiodistally expanded and very procumbent; in p3-4 the trigonid and talonid exhibit a similar development. Following Sinclair (1909), I. extensum is distinguished from I. robustum by a smaller 13 and the presence of a straight fronto-nasal suture in the former, but the author himself expressed doubt about whether these differences are specific or interindividual in nature. Likewise, Sinclair (1909) distinguished I. excavatum by its lyre-shaped temporal ridges, but the taxonomic value of this feature needs to be re-evaluated (Cassini et al., 2012).

\section{Interatherium sp.}

Figure 7.9-17

Referred material. See Appendix 2.

Geographic distribution. BB (Estancia Aguada Grande and Estancia Santa Lucia) and SBB (Estancia Cordón Alto and Estancia El Tordillo).

Stratigraphic distribution. Santa Cruz Formation (Early-Middle Miocene).

Comments. No referred specimens exhibit any of the bony structures (e.g., cranial sutures, premaxilla and anterior region of the maxilla) and dental elements (e.g., I3 and C) described by Sinclair (1909) that permit a specific identification.

\section{DISCUSSION AND CONCLUSIONS}

\section{Taxonomic richness from the Río Santa Cruz and com- parison with the coastal localities}

Based on the new specimens collected in the exposures of the SCF in Barrancas Blancas, Segundas Barrancas Blancas and Yaten Huageno at the RSC, and following the current taxonomic schemes, with the observations already made throughout this work, this contribution recognizes one genus (Astrapotherium) and a single species (A. magnum) within Astrapotheria, and seven genera (Pachyrukhos, Hegetotherium, Protypotherium, Interatherium, Homalodotherium, Nesodon and Adinotherium) and eight species (Pachyrukhos moyani, Hegetotherium mirabile, Protypotherium attenuatum, P. australe, P. praerutilum, Interatherium sp., Nesodon imbricatus and Adinotherium ovinum) among the Notoungulates.

The generic richness of the astrapotheres and notoun- gulates recorded in $\mathrm{BB}, \mathrm{SBB}$ and $\mathrm{YH}$ only differs from the one presented by Scott $(1912,1927,1937)$ and Sinclair (1909) for the RSC in the absence of Hyperoxotodon in our sample. In a specific level, our ungulate richness is lower than the one presented by these authors. This could be associated to the fragmentary state of many of the collected materials that prevent us from providing identifications at the species level (e.g., Homalodotherium sp., Nesodon sp., Adinotherium sp., Protypotherium sp., Interatherium sp. and Adinotherium sp.)

According to the dates in Cuitiño et al. (2016), the sedimentary succession from BB extends from $\sim 17.45$ to $\sim 16.49 \mathrm{Ma}$, which is likely older than SBB $(\sim 16.32$ to $\sim 15.63$ $\mathrm{Ma})$, but it is synchronous with the succession at $\mathrm{YH}(\sim 17.22$ to $\sim 16.67 \mathrm{Ma}$ ). In BB and SBB, we were able to identify almost the same faunal content regarding astrapotheres and notoungulates. Notably, the two localities differ by the presence of Pachyrukhos at SBB, which has been abundantly identified in the entire stratigraphic column. This genus has also been recognized (M. Fernández, pers. obs.) in the coastal localities Cerro Observatorio (= Monte Observación; Vizcaíno et al., 2012b) ( 17.80 to $16.30 \mathrm{Ma}$; Cuitiño et al., 2016) from materials housed at MACN-A, Killik Aike Norte (Sinclair, 1909) ( 17.0 to 15.9 Ma; Cuitiño et al., 2016), and Puesto Estancia La Costa (e.g., left mandibular fragment with four cheek teeth MPM-PV 17489) ( 17.50 to 16.70 Ma; Cuitiño et al., 2016). Cerro Observatorio is synchronous with BB, whereas the fossils recovered from Killik Aike Norte ( 17.0 to 16.9 Ma; Cuitiño et al., 2016) and Puesto Estancia La Costa ( 17.5 to 17.4 Ma; Cuitiño et al., 2016) are younger than those collected from BB ( 17.0 to 16.5 Ma; Cuitiño et al., 2016). Therefore, the absence of Pachyrukhos in BB could be associated with a regional difference or a population movement event (a hypothesis that cannot be tested at the moment). YH differs from BB and SBB in the absence of all the Typotheria, Homalodotheriidae and Nesodon; the sample obtained in $\mathrm{YH}$ is by far the smallest so the observed differences could be associated with the incomplete sampling obtained in $\mathrm{YH}$, and do not represent a real difference in the ungulate diversity.

At the species level, the main differences observed between BB, SBB and YH are the exclusive presence of Nesodon 
imbricatus in BB, Adinotherium ovinum and Pachyrukhos moyani in SBB, and Astrapotherium magnum in $\mathrm{YH}$. However, in those localities in which these species have not been identified, a large number of specimens are assigned to Nesodon sp., Adinotherium sp. and, to a lesser extent, Astrapotherium sp. In his recent unpublished revision, Hernández del Pino (2018) concludes that Nesodon imbricatus and Adinotherium ovinum are the only valid species of each respective genus. If so, all Nesodon sp. and Adinotherium sp. should be allocated to $N$. imbricatus and A. ovinum, respectively. Only in this context, Nesodon imbricatus would be present in BB and SBB, whereas Adinotherium ovinum would be also present in $\mathrm{YH}$, and, as a result, these differences are equal to those mentioned for the generic level.

The astrapothere and notoungulate generic richness already described for $\mathrm{BB}, \mathrm{SBB}$ and $\mathrm{YH}$ matches the one registered in the well-known coastal localities when comparing to the information given by Scott $(1912,1927,1938)$, Sinclair (1909), Tauber (1997a,b), Tauber et al. (2004, 2008) and Cassini et al. (2012). But differs from Tauber (1999) since this author recognized the Interatheriinae Cochilius a genus known from the Deseadan (Late Oligocene) to the Colhuehuapian (Early Miocene) SALMAs of Patagonia (Reguero et al., 2003)- at the Estancia La Costa locality. Tauber (1999) did not make any further comment nor publish any details in support of this unusual occurrence, nor does this taxon appear in the large samples collected at this locality over the past twenty years, so we have reservations about the identification. On the other hand, when comparing the specific richness among BB, SBB and $\mathrm{YH}$, and the eastern localities, the one from the RSC is reduced since only Nesodon imbricatus, Adinotherium ovinum, Protypotherium australe, P. attenuatum, P. praerutilum, Hegetotherium mirabile, Pachyrukhos moyani and Astrapotherium magnum have been identified in the area. All these species are also recorded for the coastal localities, associated to several species not present at the RSC: Interatherium robustum, I. extensum, I. excavatum, Adinotherium robustum, Homalodotherium segoviae, $H$. cunnighami, H. crassum, Astrapotherium nanum? and Nesodon conspurcatus. Tauber (1999) identified Homalodotherium rutimeyeri, but we follow Scott (1912) in placing H. rutimeyeri in synonymy with $N$. conspurcatus.

\section{Paleoenvironmental inferences}

The paleoecological interpretations and comparisons were made at a genus level following most of the inferences in the studies performed with the coastal materials both in the taxa analysed here and in other clades (e.g., Cassini et al., 2012; Cassini, 2013; Toledo et al., 2013, 2015; Muñoz et al., 2017, 2019).

As stated above, the sample of $\mathrm{YH}$ is considerably smaller than the one from the other localities and only two of the three largest ungulates have been found (Astrapotherium and Adinotherium). If this is not due to sampling error, it would mean the absence of small body mass ungulates and a deeper analysis would be necessary to find some explanation. This could be related to ecological reasons (the temporary span is similar to $\mathrm{BB}$ ) or to taphonomic reasons (the environment on the west would have been one with more energy than the one towards the east; Fernicola et al., 2014).

The other two localities present virtually the same richness of the ungulates treated in this contribution. The only difference is the presence of Pachyrukhos in SBB and its absence in BB. As mentioned above, this discrepancy is not related with the differences in temporality (e.g., Pachyrukhos is present in Monte Observación, Killik Aike Norte and Puesto Estancia La Costa). The absence of this genus in the easternmost locality treated here is lacking the smallest Santacrucian ungulate. Pachyrukhos was probably a rapid runner and the most agile among the typotheres and would have been a grazer of open environments (Cassini et al., 2012). Its absence could be interpreted as indicative of less open areas in BB than in SBB. Overall, the similarity between the ungulate fauna of Río Santa Cruz and the one in the coastal localities (all the same genera), except for the presence of Hyperoxotodon in the former (Ameghino, 1887b), could lead to interpret the environment in a similar way, a complex mosaic of open and closed habitats (Cassini et al., 2012; Kay et al., 2012; Vizcaíno et al., 2012a). This inference should be contrasted with the remaining taxa and sedimentological evidences.

\section{ACKNOWLEDGMENTS}

We thank the following persons and institutions: the reviewers for the useful comments, the editors of the thematic volume "Early-Middle Miocene paleontology in the Río Santa Cruz, Southern Patagonia, Argentina. 130 years since Ameghino, 1887", 
J.C. Fernicola, M.S. Bargo, S.F. Vizcaíno, and R.F. Kay for inviting us to participate. We also thank the Dirección de Patrimonio Cultural and the MPM (Río Gallegos, Province of Santa Cruz) for permission and support for the fieldwork in Santa Cruz, and every people involved in the successive field works. We are grateful to the curators M. Reguero (MLP), L. Chornogubsky (MACN), and M. Ezcurra (MACN) and former curator A. Kramarz (MACN) for making available the collections under their care. Tec. G. Aguirrezabala (MACN), and M. Miñana (MACN) for the preparation of several materials. This is a contribution to projects PIP-CONICET 00781 and CBLUJ 0000030-18 (J.C. Fernicola); PICT 2013-0389, and UNLP 11N/867 (S.F. Vizcaíno); PICT 2017-1081 (M.S. Bargo), and National Science Foundation 0851272 and 1348259, and National Geographic Society 9167-12 (R.F. Kay).

\section{REFERENCES}

Ameghino, C. 1890. Exploraciones geológicas en la Patagonia. Boletín del Instituto Geográfico Argentino 11: 3-46.

Ameghino, F. 1885. Nuevos restos de mamíferos fósiles oligocenos, recogidos por el profesor Pedro Scalabrini y pertenecientes al Museo Provincial de la Ciudad del Paraná. Boletín de la Academia Nacional de Ciencias de Córdoba 8: 5-207.

Ameghino, F. 1887a. Observaciones generales sobre el orden de mamíferos extinguidos sub-americanos llamados Toxodontes (Toxodontia) y sinopsis de los géneros y especies hasta ahora conocidos. Anales del Museo de La Plata 1: 1-66.

Ameghino, F. 1887b. Enumeración sistemática de las especies de mamíferos fósiles coleccionados por Carlos Ameghino en los terrenos eocenos de la Patagonia austral y depositados en el Museo La Plata. Boletín del Museo de La Plata 1: 1-26.

Ameghino, F. 1889. Contribución al conocimiento de los mamíferos fósiles de la República Argentina. Actas de la Academia Nacional de Ciencias de Córdoba, 6: i-xxxii, 1-1027, atlas of 98 pls.

Ameghino, F. 1891a. Nuevos restos de mamíferos fósiles descubiertos por Carlos Ameghino en el Eoceno inferior de la Patagonia Austral. Especies nuevas, adiciones y correcciones. Revista Argentina de Historia Natural 1: 286-328.

Ameghino, F. 1891b. Observaciones críticas sobre los mamíferos eocenos de la Patagonia austral. Revista Argentina de Historia Natural 1: 328-382.

Ameghino, F. 1891c. Caracteres diagnósticos de cincuenta especies nuevas de mamíferos fósiles argentinos. Revista Argentina de Historia Natural 1: 129-167.

Ameghino, F. 1891d. Los monos fósiles del Eoceno de la República Argentina. Revista Argentina de Historia Natural 1: 383-395.

Ameghino, F. 1894. Énumération synoptique des espèces de mammifères fossiles des formations éocènes de Patagonie. Coni e hijos, Buenos Aires, $196 \mathrm{p}$.

Ameghino, F. 1899. Sinopsis geológico-paleontológica de la Argentina, Correspondencia científica. In: A.J. Torcelli (Ed.), Obras Completas y Correspondencia Científica de Florentino Ameghino. Taller de Impresiones Oficiales del Gobierno de la Provincia de Buenos Aires, La Plata, p. 485-734.

Ameghino, F. 1900-1902. L'âge des formations sédimentaires de Patagonie. Anales de la Sociedad Cientifica Argentina 50: 109130, 145-165, 209-229; 51: 20-39; 52: 65-91, 189-197, 244-250; 54: 161-180, 220-249, 283-342.

Ameghino, F. 1907. Les toxodontes a'cornes. Anales del Museo Nacional de Historia Natural de Buenos Aires 16: 49-91.

Billet, G. 2010. New Observations on the Skull of Pyrotherium (Pyrotheria, Mammalia) and New Phylogenetic Hypotheses on
South American Ungulates. Journal of Mammalian Evolution 17: 21-59.

Billet, G. 2011. Phylogeny of the Notoungulata (Mammalia) based on cranial and dental characters. Journal of Systematic Palaeontology 9: 481-497.

Billet, G., De Muizon, C., and Mamani Quispe, B. 2008. Late Oligocene mesotheriids (Mammalia, Notoungulata) from Salla and Lacayani (Bolivia): implications for basal mesotheriid phylogeny and distribution. Zoological Journal of the Linnean Society 152: 153-200.

Bond, M. 1986. Los ungulados fósiles de Argentina: evolución y paleoambientes. $4^{\circ}$ Congreso Argentino de Paleontología y Bioestratigrafía (Mendoza), Actas 2: 173-185.

Bond, M. 1999. Quaternary native ungulates of Southern South America. A synthesis. In: J. Rabassa, and M. Salemme (Eds.), Quaternary of South America and Antarctic Peninsula. Centro Austral de Investigaciones Científicas and Universidad Nacional de la Patagonia, Ushuaia, p. 177-205.

Bond, M., Cerdeño, E., and López, G. 1995. Los ungulados nativos de América del Sur. In: M.T. Alberdi, G. Leone, and E.P. Tonni (Eds.), Evolución biológica y climática de la región Pampeana durante los últimos cinco millones de años. Un ensayo de correlación con el Mediterráneo occidental. Monografías del Museo Nacional de Ciencias Naturales, Consejo Superior de Investigaciones Científicas, Madrid, p. 259-275.

Buckley, M. 2015. Ancient collagen reveals evolutionary history of the endemic South American 'ungulates'. Proceedings of the Royal Society B 282: 1806 doi: 10.1098/rspb.2014.2671

Burmeister, G. 1879. Description physique de la République Argentine. D'après des observations personnelles et étrangères. Imprenta Paul-Émile Coni, Buenos Aires, Argentina, 553 p.

Cassini, G.H. 2013. Skull geometric morphometrics and paleoecology of Santacrucian (late early Miocene; Patagonia) native ungulates (Astrapotheria, Litopterna, and Notoungulata). Ameghiniana 50: 193-217.

Cassini, G.H., Cerdeño, E., Villafañe, A., and Muñoz, N.A. 2012. Paleobiology of Santacrucian native ungulates (Meridiungulata; Astrapotheria, Litopterna and Notoungulata). In: S.F. Vizcaíno, R.F. Kay, and M.S. Bargo (Eds.), Early Miocene Paleobiology in Patagonia: High-Latitude Paleocommunities of the Santa Cruz Formation. Cambridge University Press, Cambridge, p. 243-286.

Cifelli, R.L. 1985. South American ungulate evolution and extinction. In: F.G. Stehli, and S.D. Webb (Eds.), The Great American Biotic Interchange. Plenum Press, New York, p. 249-266.

Cifelli, R.L. 1993. The phylogeny of the native South American ungulates. In: F.S. Szalay, M.J. Novacek, and M.C. Mckenna (Eds.), Mammals Phylogeny: Placentals. Springer-Verlag, New York and London, p. 195-216.

Croft, D.A. 1999. Placentals: endemic South American ungulates. In: R. Singer (Ed.), The Encyclopedia of Paleontology. Fitzroy-Dearborn, Chicago, p. 890-906.

Croft, D.A., Flynn, J.J., and Wyss, A.R. 2004. Notoungulata and Litopterna of the early Miocene Chucal Fauna, northern Chile. Fieldiana: Geology (New Series) 50: 1-49.

Croft, D.A., Radic, J.P., Zurita, E., Charrier, R., Flynn, J.J., and Wyss, A.R. 2003. A Miocene toxodontid (Mammalia: Notoungulata) from the sedimentary series of the Cura-Mallín Formation, Loquimay, Chile. Revista Geológica de Chile 30: 285-298.

Cuitiño, J.I., Fernicola, J.C., Kohn, M.J., Trayler, R., Naipauer, M., Bargo, M.S., Kay, R.F., and Vizcaíno, S.F. 2016. U-Pb geochronology of the Santa Cruz Formation (early Miocene) at the Río Bote and Río Santa Cruz (southernmost Patagonia, Argentina): Implica- 
tions for the correlation of fossil vertebrate localities. Journal of South American Earth Sciences 70: 198-210.

Cuitiño, J.I., Fernicola, J.C., Raigemborn, M.S., and Krapovickas, V. 2019. Stratigraphy and depositional environments of the Santa Cruz Formation (Early-Middle Miocene) along the Río Santa Cruz, Southern Patagonia, Argentina. In: J.C. Fernicola, M.S. Bargo, S.F. Vizcaíno, and R.F. Kay (Eds.), Early-Middle Miocene Paleontology in the Rio Santa Cruz, Southern Patagonia, Argentina. 130 years since Ameghino, 1887. Publicación Electrónica de la Asociación Paleontológica Argentina 19: 14-33.

Elissamburu, A. 2011. Estimación de la masa corporal en géneros del Orden Notoungulata. Estudios Geológicos 68: 91-11 doi:10.3989/egeol.40336.133

Farro, M.E. 2009. La formación del Museo de La Plata. Coleccionistas, comerciantes y naturalistas viajeros a fines del Siglo XIX. Prohistoria ediciones, Rosario, Argentina, $230 \mathrm{p}$.

Fernández, M., Fernicola, J.C., and Cerdeño, E. 2019a. The genus Patriarchus Ameghino, 1889 (Mammalia, Notoungulata, Typotheria), from the Santa Cruz Formation, Santa Cruz Province, Argentina. Journal of Vertebrate Paleontology doi: 10.1080/02724634.2019.1613416

Fernández, M., Fernicola, J.C., and Cerdeño, E. 2019b. On the type materials of the genera Interatherium Ameghino, 1887 and Icochilus Ameghino, 1889 (Interatheriidae, Notoungulata, Mammalia) from early Miocene of the Santa Cruz Province, Argentina. Zootaxa 4543: 195-220.

Fernández, M., Fernicola, J.C., Cerdeño, E., and Reguero, M.A. 2018. Identification of type materials of the species of Protypotherium Ameghino, 1885 and Patriarchus Ameghino, 1889 (Notoungulata: Interatheriidae) erected by Florentino Ameghino. Zootaxa 4387: 473-498.

Fernicola, J.C. 2011a. 1886-1888: Ascenso, auge y caída de la sociedad entre Florentino Ameghino y Francisco P. Moreno. Publicación Electrónica de la Asociación Paleontológica Argentina 12: 35-49.

Fernicola, J.C. 2011b. Implicancias del conflicto Ameghino-Moreno sobre la colección de mamíferos fósiles realizada por Carlos Ameghino en su primera exploración al río Santa Cruz, Argentina. Revista del Museo Argentino de Ciencias Naturales nueva serie 13: 41-57.

Fernicola, J.C., Bargo, M.S., Vizcaíno, S.F., and Kay, R.F. 2019. Historical background for a revision of the paleontology of the Santa Cruz Formation (Early-Middle Miocene) along the Río Santa Cruz, Patagonia, Argentina. In: J.C. Fernicola, M.S. Bargo, S.F. Vizcaíno, and R.F. Kay (Eds.), Early-Middle Miocene Paleontology in the Río Santa Cruz, Southern Patagonia, Argentina. 130 years since Ameghino, 1887. Publicación Electrónica de la Asociación Paleontológica Argentina 19: 1-13.

Fernicola, J.C., Cuitiño, J.I., Vizcaíno, S.F., Bargo, M.S., and Kay, R.F. 2014. Fossil localities of the Santa Cruz Formation (early Miocene, Patagonia, Argentina) prospected by Carlos Ameghino in 1887 revisited and the location of the Notohippidian. Journal of South American Earth Sciences 52: 94-107.

Fleagle, J.H., Perkins, M.E., Heizler, M.T., Nash, B., Bown, T.M., Tauber, A.A., Dozo, M.T., and Tejedor, M.F. 2012. Absolute and relative ages of fossil localities in the Santa Cruz and Pinturas Formations. In: S.F. Vizcaíno, R.F. Kay, and M.S. Bargo (Eds.), Early Miocene Paleobiology in Patagonia: high-latitude paleocommunities of the Santa Cruz Formation. Cambridge University Press, Cambridge, p. 41-58.

Flower, W.H. 1873. On a newly discovered extinct ungulate mammal from Patagonia, Homalodontotherium cunninghami. Philosophical
Transactions of the Royal Society of London 164: 173-182.

Gelfo, J.N., López, G.M., and Bond, M. 2008. A new Xenungulata (Mammalia) from the Paleocene of Patagonia, Argentina. Journal of Paleontology 82: 329-335.

Hernández Del Pino, S. 2018. [Anatomía y sistemática de los Toxodontidae (Notoungulata) de la Formación Santa Cruz, Mioceno temprano, Argentina. Doctoral thesis, Facultad de Ciencias Naturales y Museo, Universidad Nacional de La Plata, La Plata, 432 p. Unpublished.].

Kay, R.F., Vizcaíno, S.F., and Bargo, M.S. 2012. A review of the paleoenvironment and paleoecology of the Miocene Santa Cruz Formation. In: S.F. Vizcaíno, R.F. Kay, and M.S. Bargo (Eds.), Early Miocene Paleobiology in Patagonia: High-Latitude Paleocommunities of the Santa Cruz Formation. Cambridge University Press, Cambridge, p. 331-365.

Kay, R.F., Vizcaíno, S.F., Bargo, M.S., Perry, J.M.G., Prevosti, F.J., and Fernicola, J.C. 2008. Two new fossil vertebrate localities in the Santa Cruz Formation (late early Miocene, Argentina), 51 degrees South latitude. Journal of South American Earth Sciences 25: 187-195.

Kramarz, A.G., and Bond, M. 2009. A new Oligocene astrapothere (Mammalia, Meridiungulata) from Patagonia and a new appraisal of astrapothere phylogeny. Journal of Systematic Palaeontology 7: 117-128.

Kramarz, A.G., Garrido, A., and Bond, M. 2019. Astrapotherium from the middle Miocene Collon Cura Formation and the decline of astrapotheres in Southern South America. Ameghiniana doi: 10.5710/AMGH.15.07.2019.3258

Lydekker, R. 1894. Contribuciones al conocimiento de los vertebrados fósiles de la Argentina. Observaciones adicionales sobre los ungulados argentinos. Anales del Museo de La Plata 2: 1-248.

Marshall, L.G., Hoffstetter, R., and Pascual, R. 1983. Mammals and stratigraphy: Geochronology of the continental mammal-bearing Tertiary of South America. Paleovertebrata, Mémoires Extraordinaires 1-93.

Marshall, L.G., and Pascual, R. 1976. Fossil localities for Santacrucian (Early Miocene) mammals, Santa Cruz Province, Southern Patagonia, Argentina. Journal of Paleontology 50: 1129-1142.

Mercerat, A. 1890. Sinopsis de la familia de los Astrapotheridae (Eoceno de Patagonia). Revista del Museo de La Plata 1: 241-255.

Mercerat, A. 1891. Notas sobre la paleontología de la República Argentina. II. Sinopsis de la familia de los Proxotodontidae conservados en el Museo de La Plata (Eoceno de Patagonia). Revista del Museo de La Plata 1: 381-444.

Mercerat, A. 1895. Contributions a l'étude systématique des Toxodontia (Haplodontheridae, Toxodontidae et Xotodontidae). Anales del Museo Argentino de Ciencias Naturales 4: 257-306.

Moreno, F.P. 1879. Viaje á la Patagonia austral: emprendido bajo los auspicios del gobierno nacional, 1876-1877. Imprenta de La Nación, Buenos Aires, 498 p.

Moreno, F.P. 1882. Patagonia. Resto de un antiguo continente sumergido. Anales de la Sociedad Científica Argentina 14: 97-131.

Muñoz, N.A., Cassini, G.H., Candela, A.M., and Vizcaíno, S.F. 2017. Ulnar articular surface 3-D landmarks and ecomorphology of small mammals: a case study of two early Miocene typotheres (Notoungulata) from Patagonia. Earth and Environmental Science Transactions of the Royal Society of Edinburgh 106: 315-323.

Muñoz, N.A., Toledo, N., Candela, A.M., and Vizcaíno, S.F. 2019. Functional morphology of the forelimb of Early Miocene caviomorph rodents from Patagonia. Lethaia 52: 91-106.

Owen, R. 1847. Notices of some fossil mammalia of South America. 
Reports of the British Association of Advancements in Science (Southampton) 16: 65-67.

Owen R. 1853. Description of some species of the extinct genus Nesodon, with remarks on the primary group (Toxodontia) of hoofed quadrupeds, to which that genus is referable. Philosophical Transactions of the Royal Society of London 143: 291-310.

Pascual, R., Ortega Hinojosa, E.J., Gondar, D., and Tonni, E. 1965. Las edades del Cenozoico mamalífero de la Argentina, con especial atención a aquellas del territorio Bonaerense. Anales de la Comisión de Investigaciones Científicas 6: 165-193.

Patterson, B. 1934. Upper premolar-molar structure in the Notoungulata with notes on taxonomy. Fieldiana: Geological Series, Field Museum of Natural History 6: 91-111.

Patterson, B., and Pascual, R. 1968. The fossil mammal fauna of South America. The Quarterly Review of Biology 43: 409-451.

Patterson, B., and Pascual, R. 1972. The fossil mammal fauna of South America. In: A. Keast, F.C. Erk, and B. Glass (Eds.), Evolution, Mammals and Southern Continents. State University of New York Press, New York, p. 274-309.

Perkins, M.E., Fleagle, J.G., Heizler, M.T., Nash, B., Bown, T.M., Tauber, A.A., and Dozo, M.T. 2012. Tephrochronology of the Miocene Santa Cruz and Pinturas Formations, Argentina. In: S.F. Vizcaíno, R.F. Kay, and M.S. Bargo (Eds.), Early Miocene Paleobiology in Patagonia: High-Latitude Paleocommunities of the Santa Cruz Formation. Cambridge University Press, Cambridge, p. 23-40.

Podgorny, I. 2009. El sendero del tiempo y de las causas accidentales. Los espacios de la prehistoria en la Argentina, 1850-1910. Prohistoria ediciones, Rosario, $331 \mathrm{p}$.

Reguero, M.A., Ubilla, M., and Perea, D. 2003. A new species of Eopachyrucos (Mammalia, Notoungulata, Interatheriidae) from the late Oligocene of Uruguay. Journal of Vertebrate Paleontology 23: 445-457.

Schmidt, G.I., Hernández del Pino, S., Muñoz, N.A., and Fernández, M. 2019. Litopterna (Mammalia) from the Santa Cruz Formation (Early-Middle Miocene) at the Río Santa Cruz, southern Argentina. In: J.C. Fernicola, M.S. Bargo, S.F. Vizcaíno, and R.F. Kay (Eds.), Early-Middle Miocene Paleontology in the Río Santa Cruz, Southern Patagonia, Argentina. 130 years since Ameghino, 1887. Publicación Electrónica de la Asociación Paleontológica Argentina 19: 170-192.

Scott, W.B. 1912. Mammalia of the Santa Cruz beds. Part II, Toxodonta of the Santa Cruz beds and Part III, Entelonychia of the Santa Cruz beds. In: W.B. Scott (Ed.), Reports of the Princeton University Expeditions to Patagonia, 1896-1899. Princeton, Princeton University, New Jersey, p. 111-300.

Scott, W.B. 1928. Mammalia of the Santa Cruz beds. Part IV. Astrapotheria. In: W.B. Scott (Ed.), Reports of the Princeton University Expeditions to Patagonia, 1896-1899. Princeton, Princeton University, New Jersey, p. 301-352.

Scott, W.B. 1937. The Astrapotheria. Proceedings of the American Philosophical Society 77: 309-393.

Seoane, F.D., and Cerdeño, E. 2019. Systematic revision of Hegetotherium and Pachyrukhos (Hegetotheriidae, Notoungulata) and a new phylogenetic analysis of Hegetotheriidae. Journal of Systematic Palaeontology 19: 1635-1663.

Simpson, G.G. 1936. Structure of a primitive Notoungulate cranium. American Museum Novitiates 824: 1-31.

Simpson, G.G. 1948. The beginning of the age of mammals in South America. Part I. Bulletin of the American Museum of Natural History 91: 1-232.

Simpson, G.G. 1967. The beginning of the age of mammals in South
America. Part II. Bulletin of the American Museum of Natural History 137: 1-260.

Simpson, G.G. 1980. Splendid Isolation, the Curious History of South American Mammals. Yale University Press, New Haven, 266 p.

Sinclair, W.J. 1909. Mammalia of the Santa Cruz beds. Part I. Typotheria. In: W.B. Scott (Ed.), Reports of the Princeton University Expeditions to Patagonia, 1896-1899. Princeton University, New Jersey, p. 1-110.

Tauber, A.A. 1994. [Estratigrafía y vertebrados fósiles de la Formación Santa Cruz (Mioceno inferior) en la costa atlántica entre las rías del Coyle y Río Gallegos, Provincia de Santa Cruz, República Argentina. Doctoral thesis, Universidad Nacional de Córdoba, Córdoba, 422 p. Unpublished.].

Tauber, A.A. 1996. Los representantes del género Protypotherium (Mammalia, Notoungulata, Interatheridae) del Mioceno Temprano del sudoeste de la Provincia de Santa Cruz, República Argentina. Academia Nacional de Ciencias (Córdoba), 95: 1-29.

Tauber, A.A. 1997a. Biostratigraphy of the Santa Cruz Formation (Lower Miocene) in southeastern Patagonia. Ameghiniana 34: 413-426.

Tauber, A.A. 1997b. Palaeoecology of the Santa Cruz Formation (Lower Miocene) in the southeast border of Patagonia. Ameghiniana 34: 517-529.

Tauber, A.A. 1999. Los vertebrados de la Formación Santa cruz (Mioceno inferior-medio) en el extremo sureste de la Patagonia y su significado paleoecológico. Revista Española de Paleontología 14: 173-182.

Tauber, A.A., Kay, R.F., and Luna, C. 2004. Killik Aike Norte, una localidad clásica de la Formación Santa Cruz (Mioceno tempranomedio), Patagonia, Argentina. Ameghiniana 41 Suplemento Resúmenes: 63R-64R.

Tauber, A.A., Palacios, M.A., Krapovickas, J., and Rodríguez, P. 2008. La Formación Santa Cruz (Mioceno Temprano-Medio) en la mitad occidental del río homónimo, Patagonia, Argentina. $17^{\circ}$ Congreso Geológico Argentino (Jujuy), Actas 2: 1500-1501.

Toledo, N., Bargo, M.S., and Vizcaíno, S.F. 2013. Muscular Reconstruction and Functional Morphology of the Forelimb of Early Miocene Sloths (Xenarthra, Folivora) of Patagonia. The Anatomical Record 296: 305-325.

Toledo, N., Bargo, M.S., and Vizcaíno, S.F. 2015. Muscular reconstruction and functional morphology of the hind limb of santacrucian (Early Miocene) sloths (Xenarthra, Folivora) of Patagonia. The Anatomical Record 298: 842-864.

Trayler, R.B., Schmitz, M.D., Cuitiño, J.I., Kohn, M.J., Bargo, M.S., Kay, R.F., Stromberg, C.A.E., and Vizcaíno, S.F. 2019. An Improved Approach to Age-Modeling in Deep Time: Implications for the Santa Cruz Formation, Argentina. Bulletin of the Geological Society of America doi:10.1130/B35203.1

Vizcaíno, S.F., Bargo, M.S., Cuitiño, J.I., Pérez, M.E., Muñoz, N.A., Aramendía, I., Tomassini R.L., and Kay, R.F. 2018. The outstanding Río Chalía (= Sehuén) outcrops of the Santa Cruz Formation (Early Miocene, Burdigalian) and its fossil vertebrate content. Publicación Electrónica de la Asociación Paleontológica Argentina 19 Suplemento de Resúmenes: 85 R.

Vizcaíno, S.F., Bargo, M.S., and Fernicola, J.C. 2013. Expediciones paleontológicas durante los Siglos XIX y XX A la Formación Santa Cruz (Mioceno Inferior, Patagonia) y destino de los fósiles. $3^{\circ}$ Congreso Argentino de Historia de la Geología (Salta), Actas 231-246.

Vizcaíno, S.F., Bargo, M.S., Kay, R.F., Fariña, R.A., Di Giacomo, M., Perry, J.M.G., Prevosti, F.J., Toledo, N., Cassini, G.H., and 
Fernicola, J.C. 2010. A baseline paleoecological study for the Santa Cruz Formation (late-early Miocene) at the Atlantic coast of Patagonia, Argentina. Palaeogeography, Palaeoclimatology, Palaeoecology 292: 507-519.

Vizcaíno, S.F., De lullis, G., Brinkman, P.D., Kay, R., and Brinkman, D.L. 2017. On an album of photographs recording fossils in the Old Collections of the Museo de La Plata and Ameghino's private collection at the beginning of the XXth century. Publicacion Electrónica de la Asociación Paleontológica Argentina 17: 14-23.

Vizcaíno, S.F., Kay, R.F., Bargo, M.S. 2012a. Early Miocene Paleobiology in Patagonia: High-latitude Paleocommunities of the Santa Cruz Formation. Cambridge University Press, Cambridge, 370 p.

Vizcaíno, S.F., Kay, R.F., Bargo, M.S. 2012b. Background for a paleoecological study of the Santa Cruz Formation (late Early Miocene) on the Atlantic Coast of Patagonia. In: S.F. Vizcaino, R.F. Kay, and M.S. Bargo (Eds.), Early Miocene Paleobiology in Patagonia: High-Latitude Paleocommunities of the Santa Cruz Formation. Cambridge University Press, Cambridge, p. 1-22.

Welker, F., Collins, M.J., Thomas, J.A., Wadsley, M., Brace, S., Cappellini, E., Turvey, S.T., Reguero, M., Gelfo, J.N., Kramarz, A.G., Burger,
J., Thomas-Oates, J., Ashford, D.A., Ashton, P.D., Rowsell, K., Porter, D.M., Kessler, B., Fischer, R., Baessmann, C., Kaspar, S., Olsen, J.V., Kiley, P., Elliott, J.A., Kelstrup, C.D., Mullin, V., Hofreiter, M., Willerslev, E., Hublin, J.J., Orlando, L., Barnes, I., and MacPhee, R. 2015. Ancient proteins resolve the evolutionary history of Darwin's South American ungulates. Nature 522: 81-84. Doi:10.1038/nature14249

Doi: 10.5710/PEAPA.19.09.2019.288

Recibido: 22 de marzo 2019

Aceptado: 19 de septiembre 2019 
APPENDIX 1 - Summary of the taxa identified in the localities from Río Santa Cruz by Ameghino (1887a,b, 1889) and Mercerat (1890, 1891) and its current nomenclatural status

Taxa

Current nomenclatural status

Astrapotheria

Nesodon magnum Owen, 1853

Astrapotherium patagonicum Burmeister, 1879

Astrapotherium burmeisteri Mercerat, 1890

Listriotherium filholi Mercerat, 1890

Notoungulata

Toxodontia

Nesodon imbricatus Owen, 1847

Nesodon sulivani Owen, 1847

Nesodon ovinum Owen, 1853

Homalodotherium cunnighami Flower, 1873

Protoxodon patagonensis Ameghino, $1887 a$

Stenotephanos speciosus Ameghino, 1887b

Lithops praevius Ameghino, $1887 \mathrm{~b}$

Protoxodon conspurcatus Ameghino, $1887 \mathrm{~b}$

Protoxodon marmoratus Ameghino, 1887b

Protoxodon obliteratus Ameghino, 1887b

Adelphotherium ligatum Ameghino $1887 \mathrm{~b}$

Acrotherium rusticum Ameghino, 1887b

Gronotherium decrepitum Ameghino, $1887 \mathrm{~b}$

Adinotherium magister Ameghino, 1887b

Adinotherium splendidum Ameghino, $1887 \mathrm{~b}$

Adinotherium proximum Ameghino, $1887 \mathrm{~b}$

Adinotherium ferum Ameghino, 1887b

Adinotherium nitidum Ameghino, $1887 \mathrm{~b}$

Phobereotherium sylvaticum Ameghino, $1887 \mathrm{~b}$

Atryptherium bifurcatum Ameghino, 1887b

Scophotherium cyclops Ameghino, $1887 \mathrm{~b}$

Rhadinotherium limitatum Ameghino, $1887 \mathrm{~b}$

Nesodon oweni Mercerat, 1891

Nesodon rutimeyeri Mercerat, 1891

Nesodon typicus Mercerat, 1891

Adinotherium pulchrum Mercerat, 1891

Adinotherium antiquum Mercerat, 1891

Nesotherium carinatum Mercerat, 1891
Astrapotherium magnum according to Ameghino (1889), Lydekker (1894), Scott (1928) and Kramarz et al. (2019)

A. magnum according to Ameghino (1889), Lydekker (1894), Scott (1928) and Kramarz et al. (2019)

Valid name according to Kramarz et al. (2019)

A. magnum according to Ameghino (1894) and Scott (1928)

Valid name according to Scott (1912)

Nesodon imbricatus according to Ameghino (1891b, 1894), Lydekker (1894) and Scott (1912)

Adinotherium ovinum according to Ameghino (1891b, 1894, 1907) and Scott (1912)

Valid name according to Scott (1912)

N. imbricatus according to Ameghino (1894) and Scott (1912)

Hyperoxotodon speciosus according to Mercerat (1895) and Madden (1990)

Toxodontia incertae sedis according to Scott (1912)

N. conspurcatus according to Ameghino (1894) and Scott (1912), but Lydekker (1894) synonimised it with $\mathbf{N}$. imbricatus

N. imbricatus according to Lydekker (1894) and Scott (1912)

N. imbricatus according to Lydekker (1894) and Scott (1912)

N. imbricatus according to Ameghino (1894), Lydekker (1894) and Scott (1912)

N. imbricatus according to Lydekker (1894) and Scott (1912)

N. imbricatus according to Scott (1912)

A. ovinum according to Scott (1912)

Valid name according to Scott (1912)

A. ovinum according to Ameghino (1904) and Scott (1912)

A. ovinum according to Scott (1912)

Valid name according to Scott (1912)

Adinotherium sylvaticum according to Mercerat (1891), Nesodon sylvaticum following Lydakker (1893), but valid name according to Scott (1912)

N. imbricatus according to Ameghino (1894), but Scott (1912) established the synonym with N. conspurcatus

N. imbricatus according to Ameghino (1894) and Scott (1912)

Toxodontia incertae sedis according to Scott (1912)

N. imbricatus according to Ameghino (1894) and Scott (1912)

N. imbricatus according to Ameghino (1894), but Scott (1912) established the synonym with N. conspurcatus.

N. imbricatus according to Scott (1912)

A. splendidum according to Ameghino (1894) and Scott (1912)

A. splendidum according to Scott (1912)

N. imbricatus according to Ameghino (1891b, 1894), but Scott (1912) established the synonym with $\mathrm{N}$. conspurcatus. 
APPENDIX 1 - Continued

\begin{tabular}{|c|c|}
\hline Taxa & Current nomenclatural status \\
\hline Nesotherium studeri Mercerat, 1891 & N. imbricatus according to Ameghino $(1891 b, 1894)$ and Scott (1912) \\
\hline Nesotherium elegans Mercerat, 1891 & $\begin{array}{l}\text { N. imbricatus according to Ameghino (1891b, 1894), but Scott (1912) established the synonym } \\
\text { with N. conspurcatus. }\end{array}$ \\
\hline Nesotherium rufum Mercerat, 1891 & N. imbricatus according to Ameghino $(1891 b, 1894)$ and Scott (1912) \\
\hline Nesotherium nehringi Mercerat, 1891 & N. imbricatus according to Ameghino $(1891 b, 1894)$ and Scott (1912) \\
\hline Nesotherium argentinum Mercerat, 1891 & N. imbricatus according to Ameghino (1891b, 1894), Lydekker (1894) and Scott (1912) \\
\hline Protoxodon evidens Mercerat, 1891 & $\begin{array}{l}\text { N. imbricatus according to Ameghino }(1891 b, 1894) \text {, but Scott (1912) established the synonym } \\
\text { with N. conspurcatus }\end{array}$ \\
\hline Protoxodon americanus Mercerat, 1891 & N. imbricatus according to Ameghino $(1891 b, 1894)$ and Scott (1912) \\
\hline Protoxodon clemens Mercerat, 1891 & N. imbricatus according to Ameghino $(1891 b, 1894)$ and Scott (1912) \\
\hline Protoxodon henseli Mercerat, 1891 & N. imbricatus according to Ameghino $(1891 b, 1894)$ and Scott (1912) \\
\hline Protoxodon speciosus Mercerat, 1891 & N. imbricatus according to Ameghino $(1891 b, 1894)$ and Scott (1912) \\
\hline Adelphotherium lutarium Mercerat, 1891 & N. imbricatus according to Ameghino (1894) and Scott (1912) \\
\hline Adelphotherium repandum Mercerat, 1891 & N. imbricatus according to Ameghino (1894), Lydekker (1894) and Scott (1912) \\
\hline Adelphotherium trivium Mercerat, 1891 & N. imbricatus according to Ameghino (1894), Lydekker (1894) and Scott (1912) \\
\hline Adelphotherium rothi Mercerat, 1891 & N. imbricatus according to Ameghino (1894) and Scott (1912) \\
\hline Adelphotherium pumilum Mercerat, 1891 & N. imbricatus according to Ameghino (1894) and Scott (1912) \\
\hline Acrotherium intermedium Mercerat, 1891 & N. imbricatus according to Ameghino (1894) and Scott (1912) \\
\hline Acrotherium mutabile Mercerat, 1891 & A. ovinum according to Scott (1912) \\
\hline Acrotherium patagonicum Mercerat, 1891 & $\begin{array}{l}\text { N. imbricatus according to Ameghino (1894), but Scott (1912) established the synonym with } \\
\text { N. conspurcatus }\end{array}$ \\
\hline Acrotherium variegatum Mercerat, 1891 & N. imbricatus according to Scott (1912) \\
\hline
\end{tabular}

Typotheria

Pachyrukhos moyani Ameghino, 1885

Interatherium rodens Ameghino, $1887 a$

Protypotherium australe Ameghino, $1887 a$

Interatherium supernum Ameghino, 1887b

Hegetotherium mirabile Ameghino, 1887b

Hegetotherium strigatum Ameghino, $1887 \mathrm{~b}$

Protypotherium praerutilum Ameghino, $1887 \mathrm{~b}$

Protypotherium attenuatum Ameghino, $1887 \mathrm{~b}$

Pachyrukhos teres Ameghino, 1889

Pachyrukhos trivius Ameghino, 1889

Pachyrukhos absis Ameghino, 1889

Pachyrukhos naevius Ameghino, 1889

Icochilus extensus Ameghino, 1889

Icochilus excavatus Ameghino, 1889

Icochilus undulatus Ameghino, 1889

Icochilus rotundatus Ameghino, 1889

Patriarchus palmidens Ameghino, 1889

Protypotherium claudum Ameghino, 1889
Valid name according to Sinclair (1909)

Typotheria incertae sedis according to Sinclair (1909)

Valid name according to Sinclair (1909)

Typotheria incertae sedis according to Sinclair (1909)

Valid name according to Sinclair (1909)

H. mirabile according to Sinclair (1909) and Seoane and Cerdeño (2019)

Valid name according to Sinclair (1909)

Valid name according to Sinclair (1909)

P. moyani according to Seoane and Cerdeño (2019)

P. moyani according to Seoane and Cerdeño (2019)

P. moyani according to Sinclair (1909) and Seoane and Cerdeño (2019)

P. moyani according to Sinclair (1909) and Seoane and Cerdeño (2019)

Interatherium extensum according to Sinclair (1909)

Interatherium excavatum according to Sinclair (1909)

Typotheria incertae sedis according to Sinclair (1909)

Typotheria incertae sedis according to Sinclair (1909)

Valid name, but the species has been proven to be collected in a western outcrop of the Santa Cruz Formation, and not from Río Santa Cruz (Fernández et al., 2019a)

P. australe according to Tauber (1996) 
Appendix 2. List of the notoungulates and astrapotheres specimens recorded in Barrancas Blancas (BB; Estancia Aguada Grande and Estancia Santa Lucia), Segundas Barrancas Blancas (SBB; Cordón Alto and Estancia El Tordillo) and Yaten Huageno (YH; Estancia El Refugio).

\section{ASTRAPOTHERIA}

\section{Astrapotheriidae}

\section{Astrapotherium magnum}

YH. MPM-PV 19927, left mandibular fragment with m1-2, talonid of right m2, and broken tusk, all from the same individual.

\section{Astrapotherium sp.}

BB. MPM-PV 19504, broken tusk; MPM-PV 19519, fragments of cheek teeth with enamel; and MPM-PV 19740, broken tusk.

SBB. MPM-PV 19719, fragments of broken teeth and enamel; MPM-PV 19759, isolated lower incisor; MPM-PV 19582, broken tusk; MPM-PV 19598, broken tusk; and MPM-PV 19918, axis.

\section{NOTOUNGULATA \\ Toxodontia \\ Homalodotherium sp.}

BB. MPM-PV 19546, broken upper cheek tooth; and MPM-PV 19563, right maxillary fragment with P4-M1?, fragment of left P2?, and tooth fragments, all from the same individual.

SBB. MPM-PV 19629, broken left M2?, and fragments of undetermined upper and lower teeth; MPM-PV 19641, fragments of upper right and left premolar; MPM-PV 19677, right C?; MPM-PV 19684, phalanx; MPM-PV 19725, two fragments of the same mandible, one with left $\mathrm{p} 4-\mathrm{m} 1$ and the other with right $\mathrm{p} 4-\mathrm{m} 2$, isolated right $\mathrm{p} 3$, p2, p1 and i1?, all from the same individual; MPM-PV 19750, left P2?; MPM-PV 19802, right maxillary fragment with P4-M1?; MPMPV 19810, astragalus and two teeth fragments; MPM-PV 19842, fragments of upper and lower cheek teeth and broken postcranial fragments; and MPM-PV 19871, right C? and fragments of broken teeth.

\section{Nesodon imbricatus}

BB. MPM-PV 19560, almost complete mandible with its dentition. Nesodonsp.

BB. MPM-PV 19515, two right mandibular fragments with p4-m1 and m2-3; MPM-PV 19568, maxillary fragment with broken M13; MPM-PV 19564, left maxillary fragment with dP3-4; MPM-PV 19530, left M1? (broken), M2 and p1; MPM-PV 19540, left M1, M2 and broken M3; MPM-PV 19543, right i2, p2, m1 or m2, and fragments of lower cheek teeth; and MPM-PV 19545, broken symphysis with broken i3 and alveoli of c-p3.

SBB. MPM-PV 19578, lingual portion of worn lower cheek tooth; MPM-PV 19615, right $\mathrm{m} 1$ or $\mathrm{m} 2$, and fragment of the premaxilla with I1(alveolus)-2; MPM-PV 19618, broken left M3; MPM-PV 19708, broken talonid of right m3; MPM-PV 19712, right mandibular fragment with dp4-m2, left mandibular fragment with erupting p3-4 and m1-3 (erupting), isolated left unworn $\mathrm{m} 3$ and right dp4, and postcranial fragments, all from the same individual; MPM-PV 19749, two mandibular fragments of the same individual with broken p2-p4 and m2-3; MPM-PV 19798, incomplete mandible with associated tooth fragments; MPM-PV 19801, isolated and broken p2, p3 and p4; MPM-PV 19829, broken right m2?; MPM-PV 19834, right P2 or P3; MPM-PV 19862, both $\mathrm{p4}$, right $\mathrm{m} 1$, and left $\mathrm{m} 2$; and MPM-PV 19894, two mandibular fragments from the same individual, one with left $\mathrm{m} 1$ (broken)-3 and the other with right $\mathrm{m} 2-3$.

Adinotherium ovinum

SBB. MPM-PV 19717, almost complete skull with dentition.

\section{Adinotherium sp.}

BB. MPM-PV 19488, three fragments of lower cheek teeth; MPMPV 19491, broken left M1 or M2; MPM-PV 19497, several fragments of a mandible, including a right mandibular fragment with broken $\mathrm{m} 1-2$; MPM-PV 19499, right p1, both p3, and fragments of lower cheek teeth; MPM-PV 19501, fragments of lower cheek teeth from the same individual; MPM-PV 19502, fragment of an upper cheek tooth; MPM-PV 19517, fragments of upper cheek teeth; MPM-PV 19520, right p2 and m2?, and left m1?; MPM-PV 19521, right mandibular fragment with $\mathrm{p} 4-\mathrm{m} 1$, isolated right I1 and $\mathrm{m} 3$ (unworn), all from the same individual; MPM-PV 19524, broken right m1? and m2?; MPM-PV 19528, fragments of lower cheek teeth; MPM-PV 19533, right p4?; MPM-PV 19535, left maxillary fragment with P3-M2 (broken); MPM-PV 19538, fragments of upper cheek teeth; MPM-PV 19542, broken left M3, and fragments of undetermined teeth; MPM-PV 19553, right maxillary fragment with broken P4-M1; MPM-PV 19561, badly preserved left maxillary fragment with broken P2-M1?; MPM-PV 19562, broken right i1 or i2, left mandibular fragment with broken alveoli of $\mathrm{m} 1-3$, right mandibular fragment with $\mathrm{p} 3-\mathrm{m} 2$, and broken right $\mathrm{m} 3$, all from the same individual; and MPM-PV 19567, incomplete mandible with its broken dentition.

SBB. MPM-PV 19662, trigonid of right cheek tooth; MPM-PV 19671, anterior portion of the skull with broken left I1-P3 and right 11-M1; MPM-PV 19692, anterior region of the skull with almost complete dentition poorly preserved; MPM-PV 19698, isolated p4?, m1?, and m2? (trigonid); MPM-PV 19672, left m3; MPM-PV 19718, labial portion of a lower right cheek tooth; MPM-PV 19724, left mandibular fragment with i3 and p2-3, left mandibular fragment with $\mathrm{m} 3$, and right mandibular fragment with broken $\mathrm{m} 1-3$ (trigonid); MPM-PV 19727, right mandibular fragment with m2-3; MPMPV 19745, talonid of left p3 or p4; MPM-PV 19756, right dp3 or dp4; MPM-PV 19779, isolated right P4 and M1, and two fragments of upper cheek teeth; MPM-PV 19790, right p3?, and fragments of undetermined teeth; MPM-PV 19804, right m1 or m2; MPM-PV 19818, right mandibular fragment with m2-3; MPM-PV 19833, two right maxillary fragments from the same individual with $\mathrm{P} 1$ (alveolus) -2 and P3-M3 (erupting); and MPM-PV 19882, broken left P2 or P3.

YH. MPM-PV 19928, talonid of a right cheek tooth; and MPM-PV 19929, broken right m3; and MPM-PV 19930, isolated right i1; i2?, and $\mathrm{m} 1$ or $\mathrm{m} 2$; MPM-PV 20024, right ulna and fragments of postcranial elements.

\section{Typotheria}

Hegetotheriidae

\section{Hegetotherium mirabile}

BB. MPM-PV 19487, right mandibular fragment with p2-m2; MPMPV 19489, right maxillary fragment with alveoli of P1-3, complete left P3-M1, and isolated left M3; MPM-PV 19498, left maxillary fragment with $\mathrm{M} 2$ (broken)-2, left mandibular fragment with m12, and postcranial fragments; MPM-PV 19507, left upper cheek tooth; MPM-PV 19508, left M1 or M2; MPM-PV 19511, fragments of lower and upper cheek teeth; MPM-PV 19513, right maxillary fragment with P3 (erupting)-M3; MPM-PV 19527, right mandibular fragment with p4-m2; MPM-PV 19547, left mandibular fragment with p3-4, and isolated left $\mathrm{m} 1$; and MPM-PV 19555, incomplete skull with C (alveolus)-M2 (broken), left mandibular fragment with $\mathrm{m} 1-2$, and fragments of postcranial elements.

SBB. MPM-PV 19570, right mandibular fragment with m1-2; MPMPV 19577, right lower cheek tooth; MPM-PV 19626, right maxillary 
fragment with broken P2 (alveolus) -4 and complete M1; MPM-PV 19658, left mandibular fragment with p4-m3; MPM-PV 19695, right maxillary fragment with $\mathrm{M} 2-3$, and fragments of cranial elements; MPM-PV 19733, three partial lower cheek teeth; MPM-PV 19768, left maxillary fragment with alveoli of P1-3 and complete P4; MPM-PV 19786, left mandibular fragment with m1-3 (alveolus); MPM-PV 19808, a) right mandibular fragment with $\mathrm{p} 4$ (talonid) $-\mathrm{m} 2$, and b) isolated lower right and left molar; and MPMPV 19890, right mandibular fragment with p2 (alveolus)-m1 (broken), and left $\mathrm{m} 1, \mathrm{~m} 2$ and $\mathrm{m} 3$.

\section{Pachyrukhos moyani}

SBB. MPM-PV 19644, left mandibular fragment with p4-m1?; MPM-PV 19651, left mandibular fragment with p3-m2, and isolated fragments of right lower and upper cheek teeth; MPM-PV 19654, right 11; MPM-PV 19655, two partial right cheek; MPM-PV 19656, left mandibular fragment with p4-m3 and isolated undetermined broken teeth; MPM-PV 19571, left m3 and isolated left upper cheek tooth; MPM-PV 19572, broken isolated lower cheek teeth; MPM-PV 19574, right mandibular fragment with p2 (alveolus)-3; MPM-PV 19575, two isolated lower cheek teeth; MPM-PV 19580, two isolated lower cheek teeth, and one upper cheek tooth; MPM-PV 19581, broken isolated cheek tooth; MPM-PV 19583, a) upper cheek tooth, b) left mandibular fragment with p4-m2?, c) left mandibular fragment with $\mathrm{p} 4-\mathrm{m} 3$, and mandibular fragment with broken cheek teeth; MPM-PV 19584, left mandibular fragment with p4-m1?; MPM-PV 19585, left mandibular fragment with p3-4? and broken isolated cheek teeth; MPM-PV 19590, right lower cheek tooth; MPM-PV 19594, a) isolated left m3, b) left lower cheek tooth, c) left mandibular fragment with $\mathrm{p3}-\mathrm{m3}, \mathrm{d}$ ) right mandibular fragment with p2 (alveolus)-m2; MPM-PV 19596, right upper cheek tooth; MPM-PV 19600, right mandibular fragment with p3-4?, and a right upper cheek tooth; MPM-PV 19605, left mandibular fragment with i1-m1; MPM-PV 19608, left mandibular fragment with p4-m3; MPM-PV 19610, isolated lower left cheek tooth, and upper right cheek tooth; MPM-PV 19613, isolated right cheek tooth and right mandibular fragment with m1-3; MPM-PV 19617, right mandibular fragment with p3-4? and m2-3; MPM-PV 19619, right mandibular fragment with p4-m3 (broken); MPM-PV 19621, right lower cheek tooth and right upper cheek tooth; MPM-PV 19624, broken isolated cheek teeth; MPM-PV 19634, a) right mandibular fragment with p2-4, b) left i1, left p2 and left mandibular fragment with p4-m1?; MPM-PV 19649, left mandibular fragment with p24; MPM-PV 19661, right upper cheek tooth; MPM-PV 19666, a) left mandibular fragment with $\mathrm{p} 2-\mathrm{m} 2$, b) right mandibular fragment with $\mathrm{p2}-4, \mathrm{c}$ ) three broken isolated lower cheek teeth; MPM-PV 19669, right maxillary fragment with M1-3; MPM-PV 19674, two broken cheek teeth; MPM-PV 19678, broken isolated_cheek teeth; MPM-PV 19682, broken left P3 or P4; MPM-PV 19685, broken lower cheek teeth; MPM-PV 19690, left mandibular fragment with p3-m1; MPM-PV 19693, a) left mandibular fragment with broken p2-3 and complete p4-m1, b) left mandibular fragment with p2 (alveolus)-m1 (trigonid); MPM-PV 19697, broken isolated cheek teeth; MPM-PV 19699, almost complete articulated foot; MPM-PV 19700, right mandibular fragment with m2-m3; MPM-PV 19702, left mandibular fragment with $\mathrm{m} 2-3$, broken isolated cheek teeth, and fragments of postcranial elements; MPM-PV 19704, right mandibular fragment with $\mathrm{p} 4-\mathrm{m} 2$, and left mandibular fragment with p3-m3; MPM-PV 19706, two left mandibular fragments, one with p3-4 and the other with m1-3; MPM-PV 19711, right mandibular fragment with p4-m3; MPM-PV 19720, right mandibu- lar fragment with p4-m2; MPM-PV 19721, broken upper and lower cheek teeth; MPM-PV 19744, right mandibular fragment with m13; MPM-PV 19755, left upper cheek tooth, and left mandibular fragment with p2-4; MPM-PV 19748, two mandibular fragments, each with one cheek tooth; MPM-PV 19757, left maxillary fragment with M1-3, left mandibular fragment with $\mathrm{p} 3-\mathrm{m} 3$, right mandibular fragment with $\mathrm{p} 2-\mathrm{m} 1$, and fragments of postcranial elements; MPM-PV 19769, a) left mandibular fragment with p4-m2, b) right mandibular fragment with $\mathrm{p} 4-\mathrm{m} 1$ ? , c) right mandibular fragment with p3-m2, d) left mandibular fragment with p3-m1?; MPM-PV 19778 , a) left upper cheek tooth, b) left mandibular fragment with $\mathrm{p} 2, \mathrm{c})$ left mandibular fragment with $\mathrm{p} 3-\mathrm{m} 1, \mathrm{~d})$ right mandibular fragment with two molariforms; MPM-PV 19787, upper right cheek tooth, right maxillary fragment with alveoli of $\mathrm{P}-4$, left mandibular fragment with p2 (alveolus)-4, and left mandibular fragment with broken p4-m2; MPM-PV 19788, a) right mandibular fragment with right $\mathrm{p3}-\mathrm{m3}$, b) right mandibular fragment $\mathrm{p} 3$ (erupting)-m2; MPMPV 19791, isolated cheek teeth; MPM-PV 19792, a) left mandibular fragment with $\mathrm{p} 2-3$, b) right mandibular fragment with $\mathrm{p} 2$ (alveolus)-m1, c) two lower cheek teeth; MPM-PV 19795, broken lower and upper cheek teeth; MPM-PV 19797, two broken lower cheek teeth; MPM-PV 19800, articulated skull and mandible; MPMPV 19803, articulated skull and mandible; MPM-PV 19813, right maxillary fragment with $\mathrm{P} 2-\mathrm{M} 3$, right mandibular fragment with p2-m3; MPM-PV 19816, right mandibular fragment with p3-m3; MPM-PV 19817, right maxillary fragment with P2 (alveolus)-P4; MPM-PV 19819, articulated skull and mandible; MPM-PV 19828, right mandibular fragment with p3-m1?; MPM-PV 19835, right mandibular fragment with p2 (alveolus)-4; MPM-PV 19840, isolated lower cheek teeth; MPM-PV 19850, a) right mandibular fragment with $\mathrm{p} 4-\mathrm{m} 2$, b) right mandibular fragment with $\mathrm{p} 3-2, \mathrm{c}$ ) isolated lower cheek teeth; MPM-PV 19854, left mandibular fragment with p3-m1; MPM-PV 19857, left broken lower cheek tooth; MPM-PV 19860, a) left mandibular fragment with p2-m2, b) right mandibular fragment with $\mathrm{p} 2-\mathrm{m} 1$; c) right mandibular fragment with p2 (broken)-p4; MPM-PV 19865, upper cheek teeth; MPM-PV 19866, left mandibular fragment with p3 (alveolus)-m2; MPM-PV 19867, right mandibular fragment with $\mathrm{p} 2-\mathrm{p} 3$ and m1-3, left mandibular fragment with p3-4, and two isolated lower left and right cheek teeth; MPM-PV 19874, right mandibular fragment with p2-4; MPM-PV 19880, a) lower left cheek tooth, b) left mandibular fragment with p2-3; MPM-PV 19884, broken cheek teeth; MPMPV 19892, a) left mandibular fragment with p3-m2, b) left mandibular fragment with $\mathrm{p} 4-\mathrm{m} 2, \mathrm{c}$ ) right mandibular fragment with p2 (broken)-3, d) left mandibular fragment with p2 (broken)$\mathrm{m2}$; e) right mandibular fragment with p4-m2?; MPM-PV 19895, maxillary fragment with the ectolophs of M1-M3; MPM-PV 19898, right lower cheek tooth; MPM-PV 19905, partial articulated skull and mandible, and fragments of postcranial elements; MPM-PV 19915, mandibular fragment with p4-m3, right mandibular fragment with p3-4?, left upper cheek tooth, left lower cheek tooth, and two isolated broken cheek teeth; MPM-PV 19917, palatal fragment with its dentition; MPM-PV 19919, right mandibular fragment with badly-preserved p2-m3; MPM-PV 19920, right mandibular fragment with p3-m2 (trigonid); and MPM-PV 19924, palatal fragment with left P2-M3 and right P2-M2.

\section{Interatheriidae}

\section{Protypotherium australe}

BB. MPM-PV 19539, right maxillary fragment with P3-M3.

SBB. MPM-PV 19824, left M1 or M2, and left m1 or m2; MPM-PV 
19588, right maxillary fragment with P4 (broken)-M2; MPM-PV 19593, symphysis with broken anterior dentition, right mandibular fragment with alveoli p2-4, and complete m1-2; MPM-PV 19601, right mandibular fragment with m2-3; MPM-PV 19602, right premaxillary fragment with I1-3; MPM-PV 19609, left mandibular fragment with p4-m1; MPM-PV 19616, isolated right p2, p3 and $\mathrm{p} 4$, left $\mathrm{m} 3$, and mandibular fragment with left i2-3, right i3 and left $\mathrm{c}$, left mandibular fragment with $\mathrm{p} 3-\mathrm{m} 1$, and right mandibular fragment with m1-2; MPM-PV 19620, incomplete mandible with right alveoli of $\mathrm{i} 1-\mathrm{p} 4$ and $\mathrm{m} 1-3$, left alveoli of $\mathrm{i} 1-3$ and $\mathrm{p} 1-\mathrm{m} 2$ (broken), and complete left c, right 12 , and isolated broken undetermined teeth; MPM-PV 19630, left mandibular fragment with m1-3; MPMPV 19631, left maxillary fragment with PM3-M3, right mandibular fragment with $\mathrm{p} 4-\mathrm{m} 2$, and fragments of postcranial elements; MPM-PV 19636, left mandibular fragment with m2-3; MPM-PV 19638, right mandibular fragment with m2-3; MPM-PV 19639, right mandibular fragment with p2 (alveolus)-4; MPM-PV 19642, left mandibular fragment with p2 (alveolus)-4; MPM-PV 19653, left maxillary fragment with M1-3 (broken); MPM-PV 19632, left mandibular fragment with broken $\mathrm{m} 1$ or m2; MPM-PV 19663, badly preserved skull included in sediment matrix; MPM-PV 19664, symphysis with alveoli of anterior teeth, isolated $\mathrm{m} 1, \mathrm{~m} 2$ and $\mathrm{m} 3$, left M1 or M2 left; MPM-PV 19675, left mandibular fragment with alveoli of i1-c and complete p1 (broken)-p2 (alveolus)-p3-m2; MPMPV 19676, right mandibular fragment with $\mathrm{m} 1$ (broken)-2; MPM-PV 19691 , symphysis with alveoli of left i1-c and complete left series $\mathrm{p} 1$ (broken)-2, left mandibular fragment with p4-m1 (trigonid), and right mandibular fragment with p4-m2; MPM-PV 19714, left mandibular fragment with alveoli of p3-m1 (broken), and right mandibular fragment; MPM-PV 19715, right maxillary fragment with P3-4 (alveoli)-M1-3, and left maxillary fragment with P2-4 (broken), and right palatal fragment with alveoli of I2-P2; MPM-PV 19716, incomplete skull with both I1-2, and left I3-M1; MPM-PV 19723, right mandibular fragment with $\mathrm{m} 1$ (broken alveolus)-3; MPM-PV 19728, left mandibular fragment with m1-3; MPM-PV 19736, right mandibular fragment with alveoli of i3-m1 and complete m2; MPM-PV 19746, right mandibular fragment with alveoli of c-p3 and complete p4; MPM-PV 19758, left maxillary fragment with M2-3 (broken); MPM-PV 19761, right maxillary fragment with M1-2; MPM-PV 19763, left maxillary fragment with P4 (broken)M2; MPM-PV 19767, right $\mathrm{m} 1$ or $\mathrm{m} 2$, and right $\mathrm{p} 3$ or $\mathrm{p} 4$; MPM-PV 19772 , toothless symphysis, and left mandibular fragment with $\mathrm{p} 3$ (broken)-m2; MPM-PV 19774, right mandibular fragment with broken alveolus of $\mathrm{m} 1$, broken $\mathrm{m} 2$, and lingual portion of $\mathrm{m} 2$; MPM-PV 19776, right maxillary fragment with P4 (alveolus)-M1 (broken); MPM-PV 19781, left maxillary fragment with P2-M3, and right mandibular fragment with p2-m1; MPM-PV 19782, right m3; MPM-PV 19784, mandibular fragment with $\mathrm{m} 1$ (talonid)-3 (broken); MPM-PV 19785, left mandibular fragment with m1-3, and right mandibular fragment with p4-m1; MPM-PV 19794, both M3; MPM-PV 19799, left maxillary fragment with P4-M3, right maxillary fragment with $\mathrm{C}-\mathrm{P} 2$, and premaxillary fragment with alveoli of 11-2 and complete 13; MPM-PV 19805, left mandibular fragment with broken alveoli of i2-p3 and complete p4, and isolated right m1; MPM-PV 19806, left mandibular fragment with p3-m3; MPM-PV 19815, right $\mathrm{m} 1$ and left $\mathrm{m} 3$ from the same individual; MPM-PV 19820, right maxillary fragment with PM4-M1; MPM-PV 19826, right mandibular fragment with alveoli of $\mathrm{p} 2-3$ and $\mathrm{p} 4-\mathrm{m} 1$ (broken); MPM-PV 19849, left mandibular fragment with broken alveoli of m1-2; MPM-PV 19856, left mandibular fragment with m1 (alveolus)-2; MPM-PV 19864, isolated broken cheek teeth, and postcranial elements; MPM-PV 19868, left mandibular fragment with $\mathrm{m1-2}$; MPM-PV 19870, left mandibular fragment with $\mathrm{m} 2-3$ (broken); MPM-PV 19876, badly preserved skull fragment, without teeth; MPM-PV 19877, left maxillary fragment with P4-M1; MPMPV 19878, base of $\mathrm{i} 1$ or i2, left mandibular fragment with alveoli of p1-2 and complete $\mathrm{p} 3-\mathrm{m} 1$ (trigonid), and isolated right c; MPM-PV 19879, right $13, C$ ? $P 1, P 2, P 4, M 1, M 2, M 3$, and left P3 and P4; MPM-PV 19888, right mandibular fragment with $\mathrm{p} 4-\mathrm{m} 1$ and fragments of postcranial elements; MPM-PV 19893, right maxillary fragment with $\mathrm{P} 4-\mathrm{M} 3$, and left mandibular fragments with alveoli of i1-p3 and another with m1-3; MPM-PV 19914, left m1 or m2; MPM-PV 19921, left premaxillary fragment with alveoli of I1-3, left maxillary fragment with $\mathrm{P} 3-\mathrm{M} 3$, broken symphysis with both broken $\mathrm{i} 1-2$ and right i3-c, right mandibular fragment with $\mathrm{m} 1$ (broken) -2 , left mandibular fragments with $\mathrm{p} 3-4$, another with $\mathrm{m} 3$ and another with $\mathrm{m} 1$, and fragments of postcranial elements; and MPMPV 19925, left mandibular fragment with p4-m2.

\section{Protypotherium praerutilum}

BB. MPM-PV 19484, right mandibular fragment with m1-2; MPMPV 19486, isolated left $\mathrm{m} 1$ and $\mathrm{m} 2$; MPM-PV 19492, right mandibular fragment m1-3; MPM-PV 19493, right m1 or m2; MPM-PV 19518, left mandibular fragment with m1-2; MPM-PV 19526, right mandibular fragment with p4-m2; and MPM-PV 19550, right mandibular fragment with $\mathrm{m} 2$, isolated $\mathrm{m} 1$, and two labial fragments of two molars.

SBB. MPM-PV 19586, right mandibular fragment with p4-m1; MPM-PV 19589, right M3, right $\mathrm{m1}$, left I2?, and fragments of undetermined teeth; MPM-PV 19603, right maxillary fragment with M1-2; MPM-PV 19604, left maxillary fragment with alveoli of C-P1 and P2-M3; MPM-PV 19627, both $\mathrm{m} 1$ and $\mathrm{m} 2$, and right i3 or c; MPM-PV 19635, left mandibular fragment with p4 (alveolus)-m1; MPM-PV 19637, right mandibular fragment with p4 (alveolus)-m3 (broken); MPM-PV 19643, left mandibular fragment with p1-m1 (broken), right premaxillary fragment with 11 (alveolus)-3, and isolated left M3 and P2?; MPM-PV 19659, left maxillary fragment with P3-M2; MPM-PV 19673, left mandibular fragment with m1-3 (erupting); MPM-PV 19681, right premaxillary fragment with alveoli of I1-3, one left maxillary fragment with $\mathrm{C}-\mathrm{P} 3$, and another with alveolus of $M 2$, right maxillary fragment $P 3-4$, isolated right I2?, lingual portion of right $\mathrm{M} 1$ ?, and fragments of cranial and postcranial elements ; MPM-PV 19688, right mandibular fragment with m2-3 (broken), broken left i3 or c, right I2 or I3, both P1, both P2, broken right $M 3$, left $P 3$, left $P 4$, and broken undetermined teeth; MPM-PV 19689, two broken left m1 or m2; MPM-PV 19709, left mandibular fragment with $\mathrm{p} 4$ (erupting)-m2; MPM-PV 19710, right mandibular fragment with p4 (alveolus)-m2; MPM-PV 19734, right mandibular fragment with p3-p4 (alveolus)-m1-2; MPM-PV 19737, symphysis with alveoli of right i1-p3; MPM-PV 19743, left mandibular fragment with $\mathrm{m} 1-3$ and right mandibular fragment with p2 (alveolus)-m3; MPM-PV 19764, left maxillary fragment with P3-M3 (broken); MPM-PV 19841, left mandibular fragment with alveoli of p1-2 and complete p3-4; MPM-PV 19900, left mandibular fragment with broken m2-3; MPM-PV 19911, left mandibular fragment with m2-3; MPM-PV 19923, right mandibular fragment with m1-2 (trigonid).

\section{Protypotherium attenuatum}

BB. MPM-PV 19490, right mandibular fragment with m1-2; and isolated right $\mathrm{p3}$ and p4; MPM-PV 19494, broken left m3, lingual portion of right $\mathrm{m} 1$ or $\mathrm{m} 2$, and right $\mathrm{m} 1$ or $\mathrm{m} 2$; MPM-PV 19516, 
right mandibular fragment with p4-m1; MPM-PV 19525, left mandibular fragment with p3-m1; MPM-PV 19534, right maxillary fragment with alveoli of $\mathrm{P} 3-4$ and complete $\mathrm{M} 1-2$, and isolated $\mathrm{M} 3$, left mandibular fragment with alveoli $\mathrm{p} 1-3$ and series $\mathrm{p} 4-\mathrm{m} 1$; and MPM-PV 19565, right $\mathrm{m} 1$ or $\mathrm{m} 2$.

SBB. MPM-PV 19667, right mandibular fragment with m2-3, MPMPV 19614, right p3 or p4; MPM-PV 19640, right mandibular fragment with $\mathrm{p} 4-\mathrm{m} 1 ;$ MPM-PV 19668, right maxillary fragment with P4-M2 (broken); MPM-PV 19679, left maxillary fragment with broken $\mathrm{M} 1$ or $\mathrm{M} 2$ and its posterior molar, and right 12 from the same individual; MPM-PV 19696, left m1 or m2 (almost unworn); MPM-PV 19751, right mandibular fragment with broken alveolus of $\mathrm{m} 1$, complete $\mathrm{m} 2$ and broken $\mathrm{m} 3$, and right mandibular fragment with $\mathrm{p} 3$ (broken)-m1 (trigonid); MPM-PV 19762, right maxillary fragment with alveoli of P3-4; MPM-PV 19773; right mandibular fragment with $\mathrm{p} 4$ (erupting)-m1; MPM-PV 19777, right maxillary fragment with P4-M1; MPM-PV 19793, left maxillary fragment with lingual portion of P4-M2 (alveolus), and left broken talonid of m3?; MPMPV 19812, right mandibular fragment with p4-m2 (trigonid); MPMPV 19821, skull fragment with alveoli I1-C and complete series P1 (broken)-M1 (broken); MPM-PV 19844, right mandibular fragment with m1-3; MPM-PV 19916, right $\mathrm{m} 1$ or m2; and MPM-PV 19922, isolated left $\mathrm{m} 1$ and $\mathrm{m} 2$.

\section{Protypotherium sp.}

BB. MPM-PV 19529, mandibular fragment of a juvenile individual with its symphysis and erupting $c$ and p1; MPM-PV 19537, distal humerus; and MPM-PV 19551, left mandibular fragment with m3 (talonid), and calcaneus.

SBB. MPM-PV 19576, unworn left p4; MPM-PV 19607, left maxillary fragment with $\mathrm{dP2}-4$, and fragments of postcranial elements; MPM-PV 19612, right mandibular fragment with m2-3; MPM-PV 19625, left m1 or m2; MPM-PV 19633, right dp4; MPM-PV 19657, left mandibular fragment with alveolus of m3; MPM-PV 19687, right mandibular fragment with dp2-p3-4 and isolated right i3 or $\mathrm{c}_{\text {; }}$ MPM-PV 19731, left maxillary fragment with dP3-4; MPM-PV 19738, isolated left P3?, and worn left p2; PMPM-PV 19742, left p4; MPM-PV 19754, left dP3 or dP4; MPM-PV 19796, right dP3 or dP4 right, two right p2 barely worn; MPM-PV 19809, right p1; MPM-PV 19845, two right mandibular fragments with dp3-4 and m1-2 barely worn; MPM-PV 19853, both broken P3 or P4, and broken $\mathrm{p} 3$ or p4; MPM-PV 19858, broken undetermined teeth, right P3 or P4, labial portion of left M1 or M2; MPM-PV 19901, right mandibular fragment with alveoli of p2 and unworn p3; and MPMPV 19913, mandibular fragment with both erupting dp4, and trigonid of $\mathrm{m} 1$.

\section{Interatherium sp.}

BB. MPM-PV 19483, left mandibular fragment with alveoli of p1-3 and broken p4-m1; MPM-PV 19485, left M3, and broken left M1 or M2; MPM-PV 19496, right P3?; MPM-PV 19503, right M1?, and left mandibular fragment with m1-2?; MPM-PV 19505, right mandibular fragment with alveoli of $\mathrm{i} 2-\mathrm{p} 1$ and complete series $\mathrm{p} 2-$ m1; MPM-PV 19506, right P4 or M1; MPM-PV 19510, right 11; MPM-PV 19514, right P4 or M1; MPM-PV 19522, upper and lower isolated broken cheek teeth, and fragments of postcranial elements; MPM-PV 19523, right maxillary fragment with M1-2; MPM-PV 19531, left P4 o M1; MPM-PV 19536, distal humerus; MPM-PV 19554, right $\mathrm{m} 2$ and $\mathrm{m} 3$; MPM-PV 19556, right $\mathrm{m} 1$ or $\mathrm{m} 2$, and broken symphysis with alveoli of the anterior dentition; MPM-PV 19559, left lower cheek tooth; and MPM-PV 19566, left m3.

SBB. MPM-PV 19569, two broken lower cheek teeth; MPM-PV 19579, left m3; MPM-PV 19587, right M1; MPM-PV 19591, left
M3; MPM-PV 19592, right mandibular fragment with p4-m3, left maxillary fragment with $\mathrm{C}-\mathrm{P} 3$, isolated $\mathrm{I}$, and lingual and labial portions of two upper right and left cheek teeth; MPM-PV 19597, left M1; MPM-PV 19599, right mandibular fragment with m1-3 (erupting); MPM-PV 19606, lower broken cheek tooth; MPM-PV 19611, right m3; MPM-PV 19622, left M1 or M2 left; MPM-PV 19623, right mandibular fragment with $\mathrm{p} 2-4$; MPM-PV 19628, right dP3 or dP4; MPM-PV 19645, right maxillary fragment with P4-M2; MPM-PV 19646, left maxillary fragment with P2 (alveolus)-4; MPM-PV 19647, left mandibular fragment with $\mathrm{p} 4-3$, and right mandibular fragment with m1-2; MPM-PV 19648, isolated lower broken cheek teeth; MPM-PV 19652, right mandibular fragment with a cheek tooth; MPM-PV 19660, left cheek tooth; MPM-PV 19665, right P4?; MPM-PV 19680, lower cheek tooth; MPM-PV 19683, left mandibular fragment with p1(alveolus)-m1; MPM-PV 19686, right P2 or P3 right; MPM-PV 19694, left mandibular fragment with p3-m1; MPM-PV 19701, three broken upper cheek teeth; MPM-PV 19703, right maxillary fragment with P2-M3; MPM-PV 19705, two broken right upper cheek teeth; MPM-PV 19707, left mandibular fragment with p3-4; MPM-PV 19713, right mandibular fragment with p4m3; MPM-PV 19722, left mandibular fragment with dp4-m2 (broken); MPM-PV 19726, left mandibular fragment with p3 (alveolus)-m2 (broken); MPM-PV 19729, right maxillary fragment with $M 1-2$, isolated left $P 2$, right $P 4$, left $M 1$, and left m3; MPMPV 19732, right M3; MPM-PV 19739, left mandibular fragment with p3-m2; MPM-PV 19741, two broken lower cheek teeth; MPM-PV 19747, left lower premolar; MPM-PV 19752, right mandibular fragment with $\mathrm{p} 3-\mathrm{m} 1$; MPM-PV 19760, right mandibular fragment with m2-3; MPM-PV 19770, left maxillary fragment with M1, right maxillary fragment with M1-2, right mandibular fragment with dp4m3, and fragments of postcranial elements; MPM-PV 19771, right mandibular fragment with p4-m1?; MPM-PV 19780, left maxillary fragment with $\mathrm{dP} 3-\mathrm{P} 4-\mathrm{M} 2$ (P3 below $\mathrm{dP} 3$ ), right mandibular fragment with $\mathrm{p} 4-\mathrm{m} 1$; and isolated left m3; MPM-PV 19789, right maxillary fragment with P4 (broken)-M2 (broken); MPM-PV 19811, two lower cheek teeth; MPM-PV 19822, right maxillary fragment with P2-3 (broken); MPM-PV 19825, right maxillary fragment with P3M3; MPM-PV 19830, right mandibular fragment with p3-m2; MPM-PV 19831, right cheek tooth; MPM-PV 19839, right mandibular fragment with p4 (broken)-m3; MPM-PV 19838, left mandibular fragment with p2 (alveolus)-m3; MPM-PV 19843, right cheek tooth; MPM-PV 19846, right mandibular fragment with alveoli of p1-dp2 and complete series dp3-m1; MPM-PV 19847, left mandibular fragment with $\mathrm{p3}-\mathrm{m2}$; MPM-PV 19848, left mandibular fragment with p2-m2; MPM-PV 19851, left maxillary fragment with $\mathrm{M} 1-3$, and fragments of cranial and postcranial elements; MPM-PV 19861, right P4 or M1; MPM-PV 19873, right lower cheek tooth; MPM-PV 19875, right mandibular fragment with p3-m1; MPM-PV 19881, right cheek tooth; MPM-PV 19883, right dP3; MPM-PV 19885, left M1 or M2; MPM-PV 19886, right mandibular fragment with p1 (alveolus)-p4; MPM-PV 19887, left mandibular fragment with p4-m2; MPM-PV 19889, right mandibular fragment with $\mathrm{m} 2-3$, symphysis with alveoli of anterior teeth, and isolated broken teeth; MPM-PV 19891, right M3; MPM-PV 19896, lower cheek tooth; MPM-PV 19899, two mandibular fragments with p2 (broken)-p4 and m2-3; MPM-PV 19903, left mandibular fragment with p3-m2 (alveolus); MPM-PV 19904, lower right cheek tooth, and right mandibular fragment with alveoli of $\mathrm{p} 2$ and $\mathrm{p} 4$, and complete p3; MPM-PV 19906, left M3; MPM-PV 19907, right mandibular fragment with p4-m1; MPM-PV 19910, right P4 or M1; and MPM-PV 19912, left mandibular fragment with m1-2. 
Appendix 3. Measurements ( $\mathrm{mm}$ ) of the dentition of the Santacrucian notoungulate specimens collected in the Río Santa Cruz.

TABLE 1 - Measurements of lower dentition of Nesodon imbricatus

\begin{tabular}{|c|c|c|c|c|c|c|c|c|c|c|c|c|c|c|}
\hline & \multicolumn{2}{|c|}{$i 1$} & \multicolumn{4}{|c|}{$i 2$} & \multicolumn{4}{|c|}{ i3 } & \multicolumn{4}{|c|}{ c } \\
\hline & $M D L$ & $L L L$ & $M L$ & & $L$ & & $M$ & & L & & $M L$ & & $L L$ & \\
\hline \multirow[t]{3}{*}{ MPM-PV 19560} & - & - & - & & - & & 27 & & & & 14. & & 11. & \\
\hline & \multicolumn{2}{|c|}{ p1 } & \multicolumn{2}{|c|}{$p 2$} & \multicolumn{2}{|c|}{ p3 } & \multicolumn{2}{|c|}{$p 4$} & \multicolumn{2}{|c|}{$m 1$} & \multicolumn{2}{|c|}{$m 2$} & \multicolumn{2}{|c|}{$m 3$} \\
\hline & $M D L$ & $L L L$ & $M D L$ & $L L L$ & $M D L$ & LLL & $M D L$ & $L L L$ & $M D L$ & LLL & $M D L$ & $L L L$ & $M D L$ & $L L L$ \\
\hline MPM-PV 19560 & 11.3 & 7.2 & 17.5 & 13.2 & 19.7 & 14.8 & 25.7 & 17.4 & 31.0 & 17.8 & 38.6 & 17.5 & 65.2 & 19.6 \\
\hline
\end{tabular}

TABLE 2 - Measurements of the upper dentition of Adinotherium ovinum

\begin{tabular}{|c|c|c|c|c|c|c|c|c|c|c|c|c|c|c|}
\hline & \multicolumn{2}{|c|}{11} & \multicolumn{4}{|c|}{12} & \multicolumn{4}{|c|}{13} & \multicolumn{4}{|c|}{ C } \\
\hline & $M D L$ & $L L L$ & & & LL & & $M L$ & & LL & & $M L$ & & $L L$ & \\
\hline \multirow[t]{3}{*}{ MPM-PV 19717} & - & - & & & & & 5. & & 3. & & 6 & & 3. & \\
\hline & \multicolumn{2}{|c|}{ P1 } & \multicolumn{2}{|c|}{$P 2$} & \multicolumn{2}{|c|}{ P3 } & \multicolumn{2}{|c|}{ P4 } & \multicolumn{2}{|c|}{ M1 } & \multicolumn{2}{|c|}{ M2 } & \multicolumn{2}{|c|}{ M3 } \\
\hline & $M D L$ & $L L L$ & $M D L$ & LLL & $M D L$ & $L L L$ & $M D L$ & LLL & $M D L$ & LLL & $M D L$ & LLL & $M D L$ & $L L L$ \\
\hline MPM-PV 19717 & 6.0 & 5.7 & 8.3 & 8.6 & 9.0 & 9.9 & 10.8 & 11.8 & 16.0 & 15.2 & 19.3 & 15.3 & 26.2 & 13.8 \\
\hline
\end{tabular}

TABLE 3 - Cranial measurements of Adinotherium ovinum

\begin{tabular}{lcccccccccc}
\hline & $L$ & $W c$ & Ow & Cw & Wpc & Lsc & PI & $P w P$ & $P w M$ \\
\hline MPM-PV 19717 & 230.0 & 32.0 & $>122.0$ & $152.0^{*}$ & 35.0 & 83.0 & 127.0 & 26.0 & 47.0 \\
\hline
\end{tabular}

L, length of the skull; Wc, width at postorbital constriction; Ow, Occiput width at base; CW, bicigomatic width; Wpc, width premaxillary constriction; Lsc, length sagittal crest; Pl, length of the palate in median line; PWP, Palatal width at P1; PWM, palatal width at M3. *, approximate measure.

\begin{tabular}{|c|c|c|c|c|c|c|c|c|c|c|c|c|c|c|}
\hline & \multicolumn{2}{|c|}{ P1 } & \multicolumn{2}{|c|}{$P 2$} & \multicolumn{2}{|c|}{ P3 } & \multicolumn{2}{|c|}{ P4 } & \multicolumn{2}{|c|}{ M1 } & \multicolumn{2}{|c|}{ M2 } & \multicolumn{2}{|c|}{ M3 } \\
\hline & $M D L$ & LLL & $M D L$ & $L L L$ & $M D L$ & LLL & $M D L$ & $L L L$ & $M D L$ & $L L L$ & $M D L$ & LLL & $M D L$ & LLL \\
\hline MPM-PV 19489 & - & - & - & - & 4.2 & 3.9 & 5.1 & 4.0 & 7.6 & 4.3 & - & - & 7.3 & 4.0 \\
\hline MPM-PV 19555 & 2.6 & 2.2 & 4.2 & 3.0 & 5.5 & 3.7 & 6.9 & 4.8 & 7.8 & 4.5 & - & - & - & - \\
\hline MPM-PV 19695 & - & - & - & - & - & - & - & - & - & - & $7.5+$ & $5.0+$ & $7.4^{*}$ & $4.0^{*}$ \\
\hline
\end{tabular}


TABLE 5 - Measurements of the lower dentition of Hegetotherium mirabile

\begin{tabular}{|c|c|c|c|c|c|c|c|c|c|c|c|c|c|c|}
\hline & \multicolumn{2}{|c|}{$p 1$} & \multicolumn{2}{|c|}{$p 2$} & \multicolumn{2}{|c|}{ p3 } & \multicolumn{2}{|c|}{ p4 } & \multicolumn{2}{|c|}{$m 1$} & \multicolumn{2}{|c|}{$m 2$} & \multicolumn{2}{|c|}{$m 3$} \\
\hline & $M D L$ & $L L L$ & $M D L$ & $L L L$ & $M D L$ & LLL & $M D L$ & $L L L$ & $M D L$ & $L L L$ & $M D L$ & $L L L$ & $M D L$ & $L L L$ \\
\hline MPM-PV 19487 & - & - & 2.9 & 2.1 & 4.4 & 3.4 & 5.8 & 3.9 & 7.1 & 3.7 & 7.1 & 4.0 & - & - \\
\hline MPM-PV 19527 & - & - & - & - & - & - & 5.0 & 3.0 & 6.4 & 3.2 & 6.3 & 2.9 & - & \\
\hline MPM-PV 19555 & - & - & - & - & - & - & - & - & 6.5 & 3.3 & 6.6 & 3.6 & - & - \\
\hline MPM-PV 19570 & - & & - & - & - & - & - & - & 6.0 & 3.2 & 6.8 & 3.5 & - & - \\
\hline MPM-PV 19658 & - & - & - & - & - & - & 5.8 & - & 6.1 & 3.0 & 6.1 & 2.9 & 8.6 & 2.7 \\
\hline MPM-PV 19786 & - & - & - & - & - & - & $5.9+$ & $3.0+$ & 6.1 & 2.8 & $7.0^{*}$ & $3.0^{*}$ & $10.0+$ & $3.1+$ \\
\hline MPM-PV $19808 a$ & - & - & - & - & - & - & - & - & $6.6^{*}$ & - & 6.7 & 2.5 & - & - \\
\hline
\end{tabular}

TABLE 6 - Measurements of the upper dentition of Pachyrukhos moyani

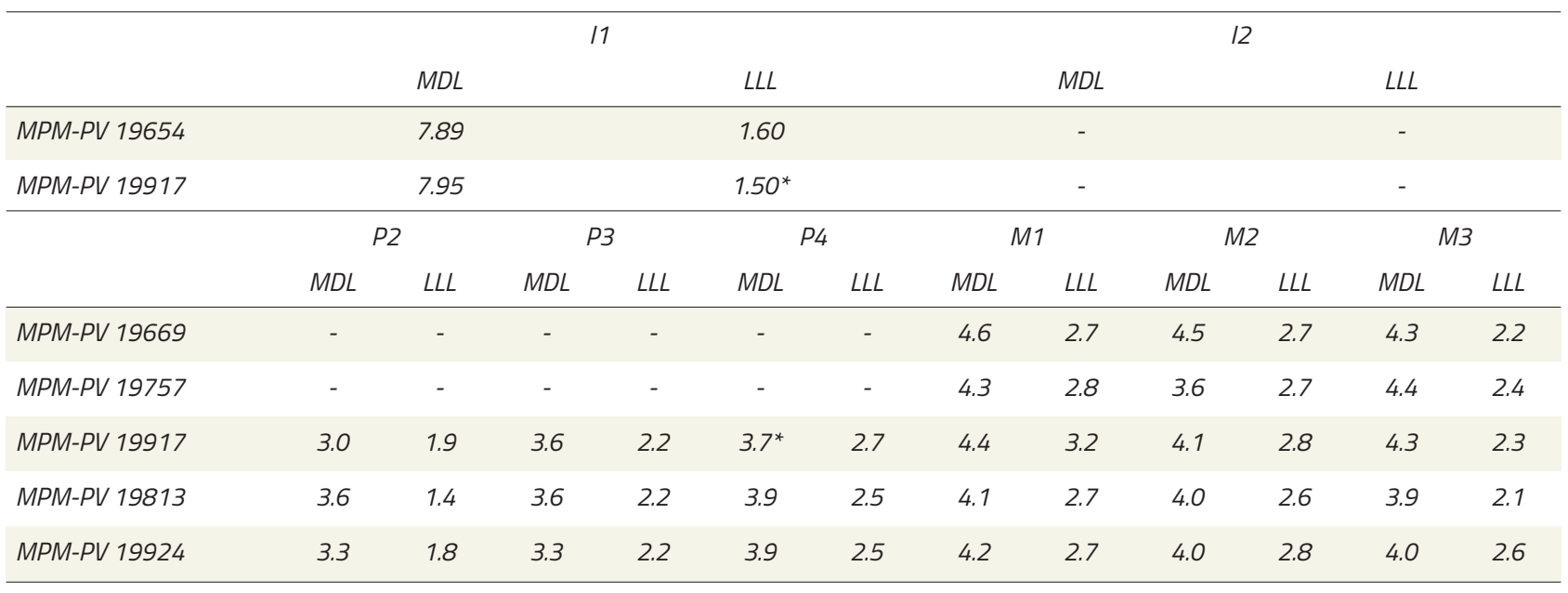

*, approximate measurements.

TABLE 7 - Measurements of the lower dentition of Pachyrukhos moyani

\begin{tabular}{|c|c|c|c|c|c|c|c|c|c|c|c|c|}
\hline & \multicolumn{6}{|c|}{$i 1$} & \multicolumn{6}{|c|}{$i 2$} \\
\hline & \multicolumn{3}{|c|}{$M D L$} & \multicolumn{3}{|c|}{ LLL } & \multicolumn{3}{|c|}{$M D L$} & \multicolumn{3}{|c|}{ LLL } \\
\hline \multirow[t]{3}{*}{ MPM-PV 19605} & & 2.97 & & & 1.22 & & & 3.09 & & & 1.10 & \\
\hline & \multicolumn{2}{|c|}{ p2 } & \multicolumn{2}{|c|}{ p3 } & \multicolumn{2}{|c|}{ p4 } & \multicolumn{2}{|c|}{$m 1$} & \multicolumn{2}{|c|}{$m 2$} & \multicolumn{2}{|c|}{$m 3$} \\
\hline & $M D L$ & LLL & $M D L$ & LLL & $M D L$ & $L L L$ & $M D L$ & $L L L$ & $M D L$ & LLL & $M D L$ & LLL \\
\hline MPM-PV $19583 a$ & - & - & - & - & 3.3 & 2.2 & 3.6 & 2.2 & 3.9 & 2.3 & - & - \\
\hline MPM-PV 19583 b & - & - & - & - & 3.2 & 2.3 & 3.6 & 2.2 & 3.8 & 2.2 & 5.1 & 2.2 \\
\hline MPM-PV 19594 a & - & - & - & - & - & - & - & - & - & - & 4.5 & 2.1 \\
\hline MPM-PV 19594 C & - & - & 3.2 & 2.0 & 3.2 & 2.2 & 3.3 & 2.0 & 3.2 & 2.1 & $5.1^{*}$ & $2.0^{*}$ \\
\hline MPM-PV $19594 d$ & $3.4+$ & $2.0+$ & 3.0 & 2.1 & 3.4 & 2.3 & 3.8 & 2.3 & 3.9 & 2.3 & - & - \\
\hline MPM-PV 19605 & 2.3 & 1.3 & 2.6 & 1.9 & 2.9 & 2.2 & 3.9 & 2.2 & - & - & - & - \\
\hline
\end{tabular}


FERNÁNDEZ AND MUÑOZ: NOTOUNGULATA AND ASTRAPOTHERIA, RÍO SANTA CRUZ

TABLE 7 - Continued

\begin{tabular}{|c|c|c|c|c|c|c|c|c|c|c|c|c|}
\hline & \multicolumn{2}{|c|}{$p 2$} & \multicolumn{2}{|c|}{ p3 } & \multicolumn{2}{|c|}{$p 4$} & \multicolumn{2}{|c|}{$m 1$} & \multicolumn{2}{|c|}{$m 2$} & \multicolumn{2}{|c|}{$m 3$} \\
\hline & $M D L$ & $L L L$ & $M D L$ & $L L L$ & $M D L$ & $L L L$ & $M D L$ & LLL & $M D L$ & $L L L$ & $M D L$ & LLL \\
\hline MPM-PV 19608 & - & - & - & - & 3.2 & 2.1 & 3.9 & 2.3 & 3.6 & 2.5 & 5.6 & 2.3 \\
\hline MPM-PV 19613 & - & - & - & - & - & - & 3.7 & 2.2 & 4.0 & 2.3 & 5.5 & 2.2 \\
\hline MPM-PV 19619 & - & - & - & - & 2.8 & 1.9 & 3.5 & 2.2 & 3.4 & 2.2 & - & - \\
\hline MPM-PV 19651 & - & - & 2.9 & 1.6 & 2.8 & 1.9 & 3.1 & 2.1 & 3.1 & 2.0 & - & - \\
\hline MPM-PV 19656 & - & - & - & - & 3.5 & 1.5 & 3.8 & 2.0 & 3.8 & 2.3 & 4.5 & 1.8 \\
\hline MPM-PV $19666 a$ & 2.3 & 1.4 & 2.5 & 2.0 & 2.5 & 2.1 & 3.2 & 2.2 & 3.2 & 2.3 & - & - \\
\hline MPM-PV $19666 b$ & 2.1 & 1.4 & 3.0 & 2.0 & 3.6 & 2.3 & - & - & - & - & - & - \\
\hline MPM-PV $19693 a$ & $2.6+$ & $1.8+$ & $3.1+$ & $1.6+$ & 3.2 & 2.2 & 3.5 & 2.3 & - & - & - & - \\
\hline MPM-PV 19693 b & $2.2+$ & $1.8+$ & 3.1 & 2.0 & 2.8 & 2.2 & - & - & - & - & - & - \\
\hline MPM-PV 19700 & - & - & - & - & - & - & - & - & 3.4 & 2.0 & 4.7 & 2.0 \\
\hline MPM-PV 19704 & - & - & 3.4 & 2.0 & 3.4 & 2.3 & 3.7 & 2.3 & 3.7 & 2.2 & 5.0 & 2.5 \\
\hline MPM-PV 19706 & - & - & 3.1 & 2.0 & 3.2 & 2.1 & 3.7 & 2.0 & 4.1 & 2.0 & 4.7 & 2.1 \\
\hline MPM-PV 19711 & - & - & - & - & 3.3 & 2.2 & 3.8 & 2.2 & 3.8 & 2.2 & 5.4 & 2.1 \\
\hline MPM-PV 19720 & - & - & - & - & 3.0 & 2.3 & 3.3 & 2.2 & 3.8 & 2.5 & - & - \\
\hline MPM-PV 19744 & - & - & - & - & - & - & 4.1 & 2.5 & 3.8 & 2.2 & 5.2 & 2.2 \\
\hline MPM-PV 19757 & - & - & 3.2 & 1.9 & 3.2 & 2.3 & 3.6 & 2.5 & 3.6 & 2.5 & $5.7^{*}$ & 2.3 \\
\hline MPM-PV $19769 a$ & - & - & - & - & 3.2 & 2.1 & 3.3 & 2.2 & 3.4 & 2.2 & - & - \\
\hline MPM-PV 19769 b & - & - & - & - & 3.3 & 2.2 & 3.5 & 2.2 & - & - & - & - \\
\hline MPM-PV 19769 c & - & - & 2.6 & 1.6 & 2.8 & 1.6 & 3.6 & 1.8 & 3.2 & 1.9 & - & - \\
\hline MPM-PV $19769 d$ & - & - & 2.3 & 1.8 & 2.6 & 2.1 & 3.0 & 2.3 & - & - & - & - \\
\hline MPM-PV $19788 a$ & - & - & 2.9 & 2.0 & 3.0 & 2.1 & 3.7 & 2.3 & 4.0 & 2.3 & 4.9 & 1.9 \\
\hline MPM-PV 19792 a & 2.5 & 1.7 & 2.6 & 2.2 & - & - & - & - & - & - & - & - \\
\hline MPM-PV 19792 b & $2.4+$ & $2.0+$ & 2.9 & 2.0 & 3.4 & 2.4 & 4.0 & 2.4 & - & - & - & - \\
\hline MPM-PV 19813 & 2.6 & $1.4^{*}$ & 2.6 & 1.9 & 2.7 & 2.1 & 3.1 & 2.2 & 3.6 & 2.1 & 5.1 & 1.8 \\
\hline MPM-PV 19816 & - & - & 2.8 & 2.1 & 3.2 & 2.1 & 4.0 & 2.2 & 3.9 & 2.2 & 5.6 & 2.3 \\
\hline MPM-PV 19828 & - & - & 2.6 & 1.6 & 3.0 & 1.7 & 3.5 & 2.0 & - & - & - & - \\
\hline MPM-PV 19835 & $2.4+$ & $1.5+$ & 2.8 & 2.0 & 3.2 & 2.1 & - & - & - & - & - & - \\
\hline MPM-PV 19850 a & - & - & - & - & 3.4 & 2.0 & 3.7 & 2.4 & 4.4 & 2.3 & - & - \\
\hline MPM-PV 19850 b & - & - & 2.9 & 1.8 & 2.6 & 2.1 & 3.2 & 2.2 & 3.7 & 2.3 & - & - \\
\hline MPM-PV 19854 & - & - & 2.8 & 1.9 & 3.4 & 2.2 & 3.3 & 2.2 & - & - & - & - \\
\hline MPM-PV 19860 a & 2.8 & 1.7 & 2.8 & 2.0 & 3.1 & 2.2 & 3.4 & 2.2 & 3.5 & 2.3 & - & - \\
\hline MPM-PV 19860 b & 2.3 & 1.4 & 2.8 & 1.9 & 3.2 & 2.2 & 3.9 & 2.3 & - & - & - & - \\
\hline MPM-PV 19860 C & - & - & 2.4 & 1.7 & 2.9 & 1.8 & - & - & - & - & - & - \\
\hline MPM-PV 19866 & - & - & $2.4+$ & $2.1+$ & $2.7+$ & 2.1 & $3.7+$ & 2.4 & $4.0^{*}$ & 2.3 & - & - \\
\hline MPM-PV 19874 & 2.0 & 1.5 & 2.5 & 1.8 & 3.4 & 1.9 & - & - & - & - & - & - \\
\hline MPM-PV 19892 a & - & - & 2.8 & 2.0 & 3.1 & 2.1 & 3.4 & 2.1 & 3.3 & 2.2 & & \\
\hline MPM-PV 19892 b & - & - & - & - & 3.0 & 1.9 & 3.0 & 2.0 & 3.2 & 2.0 & & \\
\hline MPM-PV 19892 c & - & - & 2.7 & 1.9 & - & - & - & - & - & - & - & - \\
\hline MPM-PV $19892 d$ & - & - & 2.8 & 1.8 & 2.9 & 1.8 & 3.3 & 1.8 & 3.0 & 2.0 & - & - \\
\hline MPM-PV 19892 e & - & - & - & - & 2.9 & 2.0 & 3.2 & 2.0 & 3.9 & 2.1 & - & - \\
\hline MPM-PV 19920 & - & - & 2.7 & 1.8 & 3.0 & 2.0 & 3.6 & 2.0 & - & $2.0^{*}$ & - & \\
\hline
\end{tabular}


TABLE 8 - Measurements of the upper dentition of Protypotherium australe

\begin{tabular}{|c|c|c|c|c|c|c|c|c|c|c|c|c|c|c|}
\hline & \multicolumn{2}{|c|}{11} & \multicolumn{4}{|c|}{12} & \multicolumn{4}{|c|}{13} & \multicolumn{4}{|c|}{ C } \\
\hline & $M D L$ & $L L L$ & \multicolumn{2}{|c|}{$M D L$} & \multicolumn{2}{|c|}{$L L L$} & \multicolumn{2}{|c|}{$M D L$} & \multicolumn{2}{|c|}{$L L L$} & \multicolumn{2}{|c|}{$M D L$} & \multicolumn{2}{|c|}{$L L L$} \\
\hline MPM-PV 19620 & - & - & \multicolumn{2}{|c|}{5.2} & \multicolumn{2}{|c|}{2.0} & \multicolumn{2}{|c|}{-} & \multicolumn{2}{|c|}{-} & \multicolumn{2}{|c|}{-} & \multicolumn{2}{|c|}{-} \\
\hline MPM-PV 19715 & - & - & \multicolumn{2}{|c|}{$4.8+$} & \multicolumn{2}{|c|}{$3.0+$} & \multicolumn{2}{|c|}{$4.9+$} & \multicolumn{2}{|c|}{$3.0+$} & \multicolumn{2}{|c|}{$5.8+$} & \multicolumn{2}{|c|}{$3.1+$} \\
\hline MPM-PV 19716 & 5.9 & 2.7 & \multicolumn{2}{|c|}{4.9} & \multicolumn{2}{|c|}{2.4} & \multicolumn{2}{|c|}{5.3} & \multicolumn{2}{|c|}{2.7} & \multicolumn{2}{|c|}{4.3} & \multicolumn{2}{|c|}{3.0} \\
\hline MPM-PV 19799 & - & - & \multicolumn{2}{|c|}{-} & \multicolumn{2}{|c|}{-} & \multicolumn{2}{|c|}{5.0} & \multicolumn{2}{|c|}{2.2} & & & & \\
\hline MPM-PV 19878 & - & - & & & & & & & & & & & & 5 \\
\hline MPM-PV 19879 & - & - & & & & & & & & & & & & \\
\hline & & & & & & & & & & & & & & \\
\hline & $M D L$ & $L L L$ & $M D L$ & $L L L$ & $M D L$ & $L L L$ & $M D L$ & $L L L$ & $M D L$ & $L L L$ & $M D L$ & $L L L$ & $M D L$ & LLL \\
\hline MPM-PV 19603 & - & - & - & - & - & - & - & - & 7.0 & 5.1 & 6.4 & 3.7 & - & - \\
\hline MPM-PV 19631 & - & - & - & - & 6.0 & 5.0 & 6.9 & 6.0 & 9.5 & 6.3 & 7.9 & 6.0 & 7.3 & 4.3 \\
\hline MPM-PV 19715 & $4.5+$ & $3.5+$ & $4.2+$ & $4.1+$ & 5.4 & 5.0 & $6.5+$ & - & 9.1 & 5.7 & $>7.0$ & 5.1 & 8.4 & 4.1 \\
\hline MPM-PV 19716 & 3.2 & 2.0 & 5.2 & 3.8 & 6.2 & 4.9 & 7.1 & 5.6 & 8.3 & 5.2 & & & & \\
\hline MPM-PV 19758 & - & - & - & - & - & - & - & - & $7.6^{*}$ & 5.5 & - & 4.8 & - & - \\
\hline MPM-PV 19799 & 4.5 & 2.3 & 5.3 & 3.3 & - & - & 5.7 & 5.1 & 8.4 & 5.3 & 7.6 & 4.9 & 7.0 & 4.0 \\
\hline MPM-PV 19878 & - & - & - & - & 5.2 & 3.1 & 5.0 & 3.3 & 8.1 & $4.0^{*}$ & - & - & - & - \\
\hline MPM-PV 19879 & 3.7 & 2.8 & 4.1 & 3.7 & 4.3 & 4.2 & 5.3 & 4.3 & 7.5 & 5.5 & 7.1 & 4.8 & 7.0 & 4.1 \\
\hline MPM-PV 19893 & - & - & - & - & - & - & 6.0 & 5.0 & 8.6 & 5.2 & 7.7 & 4.6 & 7.0 & 4.0 \\
\hline
\end{tabular}

TABLE 9 - Measurements of the lower dentition of Protypotherium australe

\begin{tabular}{|c|c|c|c|c|c|c|c|c|c|c|c|c|c|c|}
\hline & \multicolumn{2}{|c|}{$i 1$} & \multicolumn{4}{|c|}{$i 2$} & \multicolumn{4}{|c|}{ i3 } & \multicolumn{4}{|c|}{ c } \\
\hline & $M D L$ & LLL & \multicolumn{2}{|c|}{$M D L$} & \multicolumn{2}{|c|}{ LLL } & \multicolumn{2}{|c|}{$M D L$} & \multicolumn{2}{|c|}{ LLL } & \multicolumn{2}{|c|}{$M D L$} & \multicolumn{2}{|c|}{ LLL } \\
\hline MPM-PV 19620 & - & - & \multicolumn{2}{|c|}{-} & \multicolumn{2}{|c|}{-} & \multicolumn{2}{|c|}{ - } & \multicolumn{2}{|c|}{ - } & \multicolumn{2}{|c|}{4.7} & \multicolumn{2}{|c|}{1.9} \\
\hline \multirow[t]{3}{*}{ MPM-PV 19631} & - & - & & & & & & & & & & & & \\
\hline & \multicolumn{2}{|c|}{$p 1$} & \multicolumn{2}{|c|}{$p 2$} & \multicolumn{2}{|c|}{ p3 } & \multicolumn{2}{|c|}{$p 4$} & \multicolumn{2}{|c|}{$m 1$} & \multicolumn{2}{|c|}{$m 2$} & \multicolumn{2}{|c|}{$m 3$} \\
\hline & $M D L$ & $L L L$ & $M D L$ & $L L L$ & $M D L$ & LLL & $M D L$ & $L L L$ & $M D L$ & $L L L$ & $M D L$ & $L L L$ & $M D L$ & $L L L$ \\
\hline MPM-PV 19593 & - & - & - & - & - & - & - & - & 7.6 & 4.1 & 8.2 & 4.2 & - & - \\
\hline MPM-PV 19620 & - & - & $4.6+$ & $2.5+$ & $4.9+$ & $2.7+$ & $5.3+$ & $5.3+$ & 7.2 & 4.1 & 7.1 & 4.0 & 9.3 & 3.8 \\
\hline MPM-PV 19630 & - & - & - & - & - & - & - & - & 7.7 & 4.1 & 7.4 & 3.9 & 9.1 & 3.5 \\
\hline MPM-PV 19631 & - & - & - & - & 5.7 & 3.6 & 6.4 & 4.0 & 8.7 & 4.1 & - & - & 10.1 & 3.5 \\
\hline MPM-PV 19728 & - & - & - & - & - & - & - & - & 8.5 & 4.3 & 7.7 & 4.0 & 9.4 & 3.6 \\
\hline MPM-PV 19782 & - & - & - & - & - & - & - & - & - & - & - & - & 8.5 & 3.7 \\
\hline MPM-PV 19785 & - & - & - & - & - & - & 5.4 & 3.1 & 7.7 & 3.7 & 7.5 & 3.9 & 8.8 & 3.4 \\
\hline MPM-PV 19806 & - & - & - & - & $4.8+$ & $3.0+$ & 5.4 & 3.2 & 7.6 & 3.7 & 7.3 & 3.4 & 9.0 & 3.1 \\
\hline MPM-PV 19856 & - & - & - & - & - & - & - & - & $7.6+$ & $5.1+$ & 7.0 & 4.0 & - & - \\
\hline MPM-PV 19868 & - & - & - & - & - & - & - & - & 7.7 & 3.7 & 7.3 & 3.6 & - & - \\
\hline MPM-PV 19893 & - & - & - & - & - & - & - & - & 7.6 & 3.8 & 7.2 & 3.7 & 9.0 & 3.4 \\
\hline MPM-PV 19914 & - & - & - & - & - & - & - & - & 7.6 & 3.9 & - & - & - & - \\
\hline MPM-PV 19925 & - & - & - & - & - & - & 6.1 & 3.2 & 8.7 & 4.21 & 7.8 & 4.1 & - & - \\
\hline
\end{tabular}

,+ measurement based on the alveolus. 
TABLE 10 - Measurements of the upper dentition of Protypotherium praerutilum

\begin{tabular}{|c|c|c|c|c|c|c|c|c|c|c|c|c|c|c|}
\hline & \multicolumn{2}{|c|}{11} & \multicolumn{4}{|c|}{12} & \multicolumn{4}{|c|}{13} & \multicolumn{4}{|c|}{ C } \\
\hline & $M D L$ & LLL & & & & & & & & & & & & \\
\hline \multirow[t]{3}{*}{ MPM-PV 19681} & - & - & & & & & & & & & & & & \\
\hline & \multicolumn{2}{|c|}{ P1 } & \multicolumn{2}{|c|}{$P 2$} & \multicolumn{2}{|c|}{ P3 } & \multicolumn{2}{|c|}{ P4 } & \multicolumn{2}{|c|}{ M1 } & \multicolumn{2}{|c|}{ M2 } & \multicolumn{2}{|c|}{ M3 } \\
\hline & $M D L$ & $L L L$ & $M D L$ & $L L L$ & $M D L$ & $L L L$ & $M D L$ & LLL & $M D L$ & LLL & $M D L$ & $L L L$ & $M D L$ & LLL \\
\hline MPM-PV 19604 & $2.4+$ & $2.0+$ & 3.5 & 3.4 & 3.9 & 3.6 & 4.2 & 3.9 & 6.3 & 4.1 & 5.7 & 3.6 & 5.5 & 3.1 \\
\hline MPM-PV 19659 & - & - & - & - & 3.5 & 4.1 & 4.9 & 4.3 & 6.7 & 4.5 & 6.7 & 4.4 & - & - \\
\hline MPM-PV 19681 & 3.3 & 2.5 & 3.7 & 3.8 & 4.5 & 4.5 & 4.9 & 4.5 & - & - & - & - & - & - \\
\hline MPM-PV 19764 & - & - & - & - & $4.2^{*}$ & $4.2^{*}$ & $5.5^{*}$ & $4.6^{*}$ & - & $4.7^{*}$ & 6.5 & 4.2 & - & - \\
\hline
\end{tabular}

TABLE 11 - Measurements of the lower dentition of Protypotherium praerutilum

\begin{tabular}{|c|c|c|c|c|c|c|c|c|c|c|c|c|c|c|}
\hline & \multicolumn{2}{|c|}{ p1 } & \multicolumn{2}{|c|}{ p2 } & \multicolumn{2}{|c|}{ p3 } & \multicolumn{2}{|c|}{$p 4$} & \multicolumn{2}{|c|}{$m 1$} & \multicolumn{2}{|c|}{$m 2$} & \multicolumn{2}{|c|}{ m3 } \\
\hline & $M D L$ & LLL & $M D L$ & LLL & $M D L$ & $L L L$ & $M D L$ & LLL & $M D L$ & $L L L$ & $M D L$ & $L L L$ & $M D L$ & $L L L$ \\
\hline MPM-PV 19484 & - & - & - & - & - & - & - & - & 6.0 & 3.1 & 5.8 & 3.1 & - & - \\
\hline MPM-PV 19492 & - & - & - & - & - & - & - & - & $6.3^{*}$ & 3.4 & 6.6 & 3.3 & 8.3 & 3.4 \\
\hline MPM-PV 19493 & - & - & - & - & - & - & - & - & 6.2 & 3.5 & - & - & - & - \\
\hline MPM-PV 19518 & - & - & - & - & - & - & - & - & 6.5 & 3.6 & 6.2 & 3.6 & - & - \\
\hline MPM-PV 19526 & - & - & - & - & - & - & 4.4 & 2.9 & 6.1 & 3.5 & 5.9 & 3.5 & - & - \\
\hline MPM-PV 19586 & - & - & - & - & - & - & 4.3 & 2.9 & 6.5 & 3.1 & - & - & - & - \\
\hline MPM-PV 19623 & - & - & - & - & 4.2 & 2.1 & 4.3 & 2.6 & 6.4 & $2.9^{*}$ & - & - & - & - \\
\hline MPM-PV 19743 & - & - & - & - & 4.0 & 2.4 & 4.0 & 2.8 & 6.0 & 2.8 & 5.4 & 2.7 & 6.8 & 2.9 \\
\hline MPM-PV 19911 & - & - & - & - & - & - & - & - & - & - & $6.2+$ & 3.2 & 7.7 & 3.0 \\
\hline MPM-PV 19923 & - & - & - & - & - & - & - & - & 6.7 & 3.7 & - & - & - & - \\
\hline
\end{tabular}

TABLE 12 - Measurements of the upper dentition of Protypotherium attenuatum

\begin{tabular}{|c|c|c|c|c|c|c|c|c|c|c|c|c|c|c|}
\hline & \multicolumn{2}{|c|}{ P1 } & \multicolumn{2}{|c|}{$P 2$} & \multicolumn{2}{|c|}{ P3 } & \multicolumn{2}{|c|}{ P4 } & \multicolumn{2}{|c|}{ M1 } & \multicolumn{2}{|c|}{ M2 } & \multicolumn{2}{|c|}{ M3 } \\
\hline & $M D L$ & $L L L$ & $M D L$ & LLL & $M D L$ & $L L L$ & $M D L$ & $L L L$ & $M D L$ & LLL & $M D L$ & $L L L$ & $M D L$ & LLL \\
\hline MPM-PV 19534 & - & - & - & - & - & - & - & - & 6.2 & $4.1^{*}$ & 6.0 & 4.3 & - & - \\
\hline MPM-PV 19668 & - & - & - & - & - & - & 4.1 & 3.4 & 6.2 & 3.8 & $6.0^{*}$ & $3.7^{*}$ & - & - \\
\hline MPM-PV 19777 & - & - & - & - & - & - & 4.7 & 3.6 & 6.1 & 3.7 & - & - & - & - \\
\hline MPM-PV 19821 & 1.9 & 1.6 & 2.8 & $>2.5$ & 3.7 & $>3.5$ & 4.5 & 3.8 & $6.0^{*}$ & - & - & - & - & - \\
\hline
\end{tabular}

,+ measurement based on the alveolus; *, approximate measurement; deciduous teeth are indicate in parentheses. 
TABLE 13 - Measurements of the lower dentition of Protypotherium attenuatum

\begin{tabular}{|c|c|c|c|c|c|c|c|c|c|c|c|c|c|c|}
\hline & \multicolumn{2}{|c|}{ p1 } & \multicolumn{2}{|c|}{$p 2$} & \multicolumn{2}{|c|}{ p3 } & \multicolumn{2}{|c|}{$p 4$} & \multicolumn{2}{|c|}{$m 1$} & \multicolumn{2}{|c|}{$m 2$} & \multicolumn{2}{|c|}{ m3 } \\
\hline & $M D L$ & LLL & $M D L$ & $L L L$ & $M D L$ & LLL & $M D L$ & $L L L$ & $M D L$ & LLL & $M D L$ & $L L L$ & $M D L$ & $L L L$ \\
\hline MPM-PV 19490 & - & - & - & - & 4.2 & 2.6 & 4.4 & 2.5 & 5.4 & 3.0 & 5.6 & 3.0 & - & - \\
\hline MPM-PV 19516 & - & - & - & - & - & - & 4.0 & 3.0 & 5.4 & 3.0 & - & - & - & - \\
\hline MPM-PV 19525 & - & - & - & - & 3.9 & 2.2 & 4.7 & 2.6 & 5.6 & 2.9 & - & - & - & - \\
\hline MPM-PV 19549 & - & - & - & - & - & - & 4.5 & 2.6 & 5.3 & 3.1 & - & - & - & - \\
\hline MPM-PV 19565 & - & - & - & - & - & - & - & - & 5.9 & 3.0 & - & - & - & - \\
\hline MPM-PV 19640 & - & - & - & - & - & - & 4.0 & 2.3 & 4.7 & 2.7 & - & - & - & - \\
\hline MPM-PV 19667 & & & & & & & & & & & 4.3 & 2.3 & $6.1^{*}$ & $2.2^{*}$ \\
\hline MPM-PV 19696 & - & - & - & - & - & - & - & - & 4.8 & 2.0 & - & - & - & - \\
\hline MPM-PV 19812 & - & - & - & - & - & - & 3.5 & 2.3 & 4.9 & 2.5 & - & - & - & - \\
\hline MPM-PV 19844 & - & - & - & - & - & - & - & - & 5.9 & 2.8 & 5.7 & 2.8 & 7.1 & 2.6 \\
\hline MPM-PV 19916 & - & - & - & - & - & - & - & - & 5.6 & 3.1 & - & - & - & - \\
\hline MPM-PV 19922 & - & - & - & - & - & - & - & - & 5.9 & 3.1 & - & - & - & - \\
\hline
\end{tabular}

